\begin{abstract}
UNIVERSIDADE DE SÃO PAULO
INSTITUTO DE RELAÇÕES INTERNACIONAIS

PROGRAMA DE PÓS-GRADUAÇÃO EM RELAÇÕES

INTERNACIONAIS
\end{abstract}

GABRIEL FELIPE DANTAS CORREA ARAUJO

TRÁFICO INTERNACIONAL DE PESSOAS NO BRASIL E NA AMÉRICA LATINA: ANÁLISE COMPARADA DE POLÍTICAS PÚBLICAS

São Paulo

2015 


\author{
UNIVERSIDADE DE SÃO PAULO \\ INSTITUTO DE RELAÇÕES INTERNACIONAIS \\ PROGRAMA DE PÓS-GRADUAÇÃO EM RELAÇÕES \\ INTERNACIONAIS
}

\title{
TRÁFICO INTERNACIONAL DE PESSOAS NO BRASIL E NA AMÉRICA LATINA: ANÁLISE COMPARADA DE POLÍTICAS PÚBLICAS
}

GABRIEL F. DANTAS C. ARAUJO

Dissertação apresentada ao Programa de PósGraduação em Relações Internacionais do Instituto de Relações Internacionais da Universidade de São Paulo, para a obtenção do título de Mestre em Ciências - Programa de Pós-Graduação em Relações em Internacionais

Linha de pesquisa: Cultura e Questões Normativas nas Relações Internacionais

Orientador: Prof. Dr. Leandro Piquet Carneiro

São Paulo

2015 


\section{FICHA CATALOGRÁFICA}

ARAUJO, Gabriel F. Dantas C.

Tráfico Internacional de Pessoas no Brasil e na América Latina: Análise Comparada de Políticas Públicas

Orientador: Prof. Dr. Leandro Piquet Carneiro (IRI-USP)

93 páginas

Dissertação (mestrado) - Universidade de São Paulo, 2015

Tráfico Internacional de Pessoas, Américas, Políticas Públicas, Compliance, Protocolo de Palermo. 


\section{AGRADECIMENTOS}

Primeiramente agradeço ao Instituto de Relações Internacionais e a Universidade de São Paulo pelo apoio institucional me dado durante todo o programa de pós-graduação, as condições que me foram disponibilizadas tanto de caráter acadêmico quanto pessoal foram importantes para o meu desenvolvimento na academia. $\mathrm{O}$ apoio financeiro disponibilizado, por meio do processo no 2013/04510-3, pela Fundação de Amparo à Pesquisa do Estado de São Paulo (FAPESP) foi um notável incentivo à busca pela excelência da pesquisa.

Também agradeço ao suporte do professor Leandro Piquet, que acreditou nesta ideia e pesquisa desde seu início. Meu especial agradecimento por seus aconselhamentos, auxilio e insistente incentivo à qualidade da dissertação de mestrado.

Gostaria de agradecer também aos meus familiares, em especial meus pais - José Gilmar Araujo e Rosimaire Dantas - aos quais sem sua assistência e suporte não conseguiria ter chegado nem mesmo a graduação, quanto mais na pós-graduação, sou grato ao carinho, dedicação e amor de vocês. Em especial agradeço também a meus primos - Alvaro Almeida e Paula Pinho - pela sustentação essencial no início desta caminhada.

Não poderia deixar de agradecer a Talita Queiroz, noiva, amiga e companheira, que sempre me incentivou, me aguentou e acreditou em mim. Obrigado pela paciência, pelos conselhos, pela ajuda e por sempre estar presente ao meu lado, nos bons e maus momentos. Amo-te.

Por fim, agradeço todos aqueles que não têm visibilidade, mas foram essenciais para que minha pós-graduação fosse concluída com sucesso. Desde amigos novos e velhos deixando os obstáculos mais engraçados e prazerosos, até os funcionários que realizam diariamente seu trabalho com empenho.

Agradeço também ao Criador, que sempre me abre oportunidades únicas ao meu desenvolvimento. 


\section{SUMÁRIO}

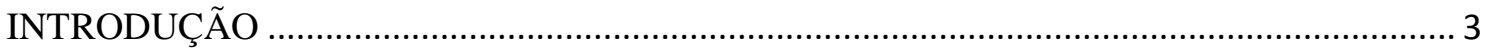

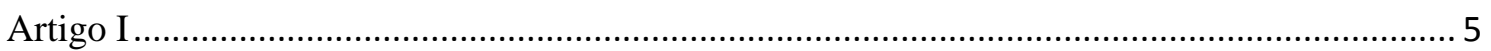

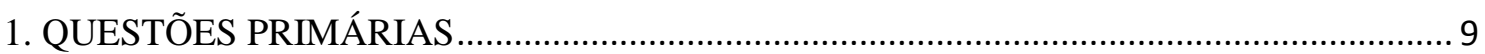

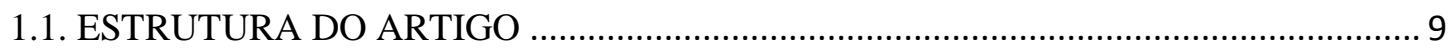

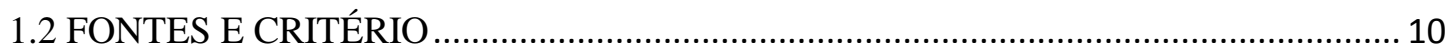

1.3 BALANÇO SOBRE A PRODUÇÃO DO TEMA........................................................... 12

2. A CONSTRUÇÃO DA ÁREA TEMÁTICA DO TRÁFICO HUMANO ................................. 13

3. AVANÇOS E LACUNAS DO OBJETO EM ANÁLISE ....................................................... 16

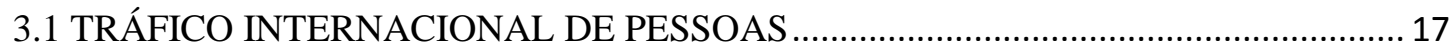

3.2 TRÁFICO DE PESSOAS E COMPLIANCE COM SEUS TRATADOS

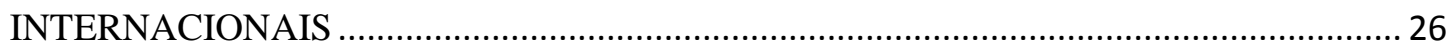

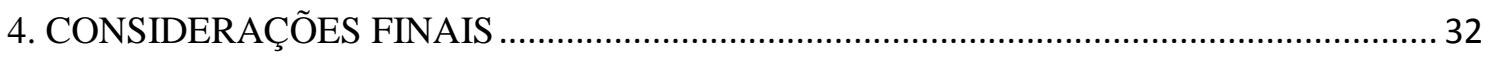

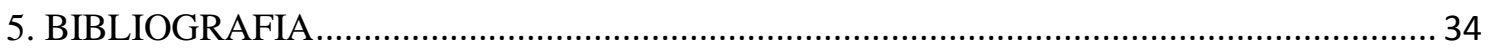

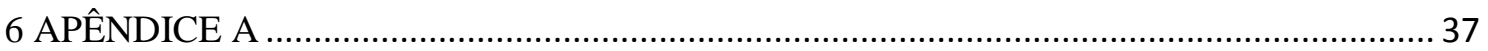

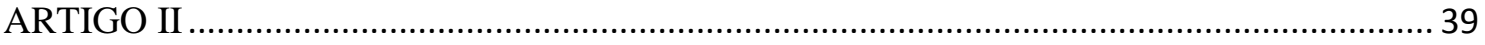

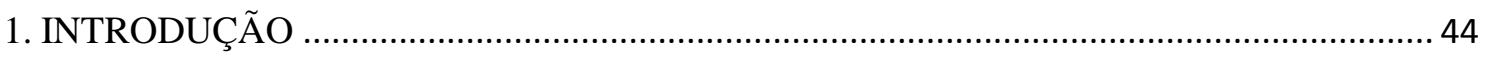

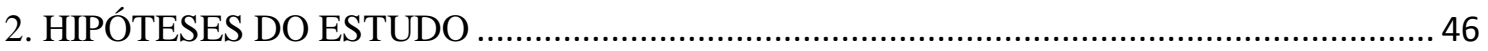

3. A CONVENÇÃO DE PALERMO E O TRÁFICO INTERNACIONAL DE PESSOAS ...... 47

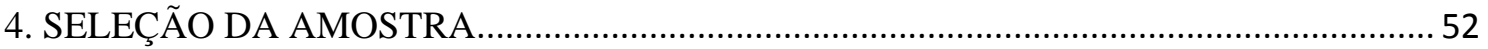

5. POLÍTICAS PÚBLICAS E PENAIS CONTRA O TRÁFICO DE PESSOAS ........................5 57

5.1 POLÍTICAS PÚBLICAS NOS PAÍSES DE ACORDO COM SEU

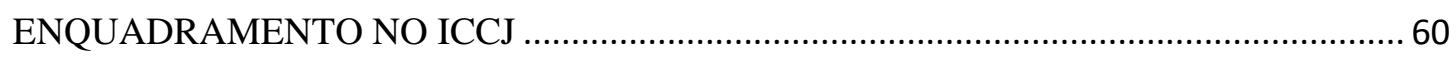

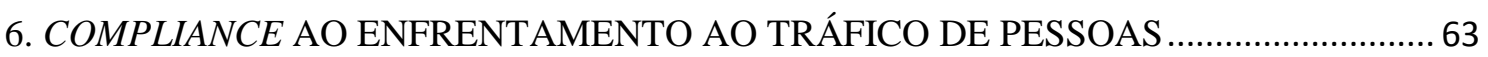

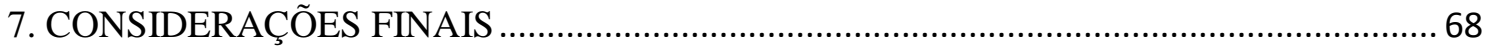

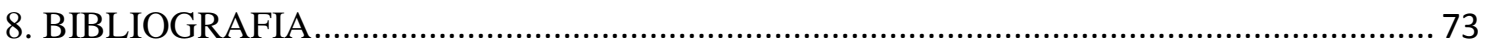

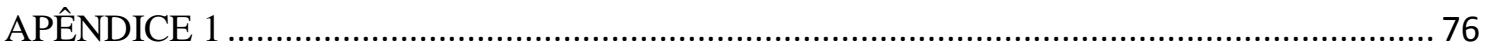

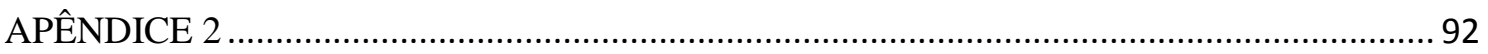

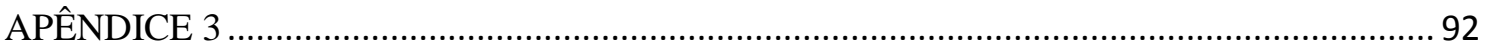




\section{INTRODUÇÃO}

O Tráfico Internacional de Seres Humanos movimenta a cada ano, em torno de US\$ 32 bilhões de dólares, segundo estimativas das Nações Unidas (ONU), configurando assim a terceira prática criminosa mais rentável do mundo, ficando atrás apenas do tráfico de drogas e contrabando de armas. Assim sendo, a ONU adotou, no início do século XXI, a Convenção de Palermo com o objetivo de promover a cooperação entre países de todo o mundo para prevenir e combater essa prática ilícita.

O presente projeto de pesquisa, cujos resultados serão expostos a seguir, realiza um estudo comparativo das principais mudanças nas legislações penais nacionais ocorridas em 13 países selecionados das Américas que foram inspiradas pela Convenção de Palermo. Descreve em que medida houve influência das diretrizes internacionais nas políticas de segurança pública doméstica, em particular no enfrentamento ao tráfico de pessoas.

O objetivo principal deste projeto consistiu em mapear os esforços de regulação penal e os programas de segurança pública adotados em países selecionados das Américas e que, em conformidade com as diretrizes da ONU, modificaram suas legislações domésticas. Integram a amostra de países: Argentina, Belize, Brasil, Chile, Colômbia, Costa Rica, El Salvador, Honduras, México, Nicarágua, Peru, Uruguai e Venezuela.

O processo de mudança na legislação dos países selecionados foi analisado como um problema de compliance dos países selecionados com relação à Convenção de Palermo. Assim, o estudo pretende avaliar quais países, dentre o conjunto estudado, mais avançaram, na adoção de medidas penais e políticas públicas voltadas para o enfrentamento ao tráfico internacional de seres humanos.

No que se refere aos métodos utilizados, o trabalho empírico teve por base uma amostra intencional de países da América Central e América do Sul, no qual foi realizado um estudo sistemático dos processos de mudança na legislação e que aproximam com o objetivo de avaliar a hipótese de que houve compliance no caso da legislação sobre o tráfico de pessoas. Devido à natureza da pesquisa, os dados mais relevantes coletados foram os registros das Leis promulgadas e ratificadas pelos países, de maneira integral ou parcial, e que se coadunam com as diretrizes postas pela Convenção de Palermo e seu Protocolo Adicional. Com base nessas informações coletadas foi construída uma tipologia das reformas ocorridas 
na legislação penal e nas políticas públicas contra o tráfico de pessoas no âmbito dos países estudados.

De maneira sintética, pode-se apontar que, por meio da pesquisa empírica, analisou-se que todos os 13 países da amostra ratificaram o Protocolo de Palermo e apresentaram esforços na criação de normas domésticas específicas para o enfrentamento ao tráfico internacional de pessoas, sendo que cada país possui uma lei própria endereçada a isto. Outra conclusão interessante foi a de que a correlação dos níveis de criminalidade organizada dos países com suas políticas públicas adotadas (no que se refere ao tráfico de pessoas) não mostraram uma interdependência direta forte. Algumas conclusões mais específicas - e mais contundentes puderam ser desenhadas, tais como: nas Américas, quanto pior as experiências prévias em relação à má influência do crime organizado e de atividades ilícitas, maiores tendem a ser as penas máximas criadas no contexto do combate ao tráfico internacional de pessoas, embora sejam justamente os países que menos apresentam casos efetivamente julgados no combate ao tráfico de pessoas; também se conclui que existem indícios de que quanto mais permeado o país esteja do crime organizado, e mais comprometido seu sistema de justiça criminal, mais iniciativas de mobilização nacional ele tende a criar. 


\section{Artigo I}

Programa de Pós-Graduação em Relações Internacionais

Universidade de São Paulo

Instituto de Relações Internacionais

TRÁFICO INTERNACIONAL DE PESSOAS: UM BALANÇO DA LITERATURA

Pesquisador: Gabriel Dantas Araujo

Orientador: Leandro Piquet Carneiro 


\section{RESUMO}

O tráfico de pessoas é um crime conhecido, porém suas consequências e sua complexidade são pouco evidenciadas e estudadas. O objetivo deste trabalho é analisar a formação da agenda de pesquisa em torno do tráfico internacional de pessoas e seu desenvolvimento atual, com o intuito de apresentar o histórico dos conceitos propostos para a análise do problema e descrever os tratados internacionais existentes. Além disso, pretende analisar as recomendações de políticas públicas encontradas na literatura estudada, cujo foco seja a prevenção e o controle do tráfico internacional de pessoas. A parte aplicada da literatura, dedicada a pensar recomendações de políticas públicas, pode ser descrita a partir da cisão entre duas vertentes principais: uma com o enfoque no papel desempenhado pelo sistema criminal no controle do tráfico e da atuação dos grupos organizados que se dedicam a essa atividade, e a outra voltada para a proteção dos Direitos Humanos, dando maior importância ao caráter preventivo desenvolvido por agentes governamentais, multilaterais e não-governamentais. Outro tema também central na literatura avaliada no presente artigo diz respeito aos desafios de compliance que enfrentam os países diante das imposições dos tratados que tratam do tráfico internacional de pessoas.

Palavras-Chave: Tráfico Internacional de Pessoas; Crime Organizado; Políticas Públicas; Compliance e Tratados Internacionais; Protocolo de Palermo. 


\title{
International Human Trafficking: a literature review
}

\begin{abstract}
Human trafficking is a known crime, but its consequences and its complexity are hardly highlighted and studied. The objective of this study is to analyze the formation of the agenda's research around the international trafficking in persons and its current development. The aim is to present a history of the concepts proposed for the analysis of the problem and describe the existing international treaties, and to analyze the policy recommendations in the studied literature and that focus on the prevention and control of international human trafficking. The applied part of literature, dedicated to thinking policy recommendations, can be described from the section between two main areas: one with the focus on the role played by the criminal justice system in trafficking control and actions of organized groups that engage in this activity, and the other focusing on the protection of human rights, giving greater importance to preventive that are developed by governmental, multilateral and nongovernmental actors. Another central theme in the literature also evaluated in this article relates to the challenges of compliance faced by countries before the imposition of treaties dealing with international trafficking in persons.
\end{abstract}

Key-Words: International Human Trafficking; Organized Crime; Public Policy; Compliance and International Treaties; Palermo Protocol. 


\section{QUESTÕES PRIMÁRIAS}

\subsection{ESTRUTURA DO ARTIGO}

O crime é uma atividade que, além de presente e perene nas sociedades, também está em constante desenvolvimento. Nas últimas décadas, impulsionados por processos econômicos benéficos como o aumento do comércio mundial, alguns crimes se tornaram mais frequentes e mais desenvolvidos do que outros. E, assim como em outras atividades, algumas práticas ilícitas também se transnacionalizaram. Pode-se considerar que algumas formas de crimes se disseminam mais rapidamente e são mais elaboradas do que outras. De acordo com o Escritório das Nações Unidas para o combate às Drogas e ao Crime (UNODC) especificamente o tráfico transnacional de drogas, o contrabando mundial de armas e o tráfico internacional de seres humanos são as três práticas criminosas que se configuram entre as mais rentáveis e combatidas em todo o mundo (THE GLOBALIZATION OF CRIME, 2010, p. 39).

Este texto discute a literatura relacionada ao tráfico internacional de pessoas, identificando as questões centrais da agenda de pesquisa na área. O objetivo do trabalho é analisar a formação da agenda de pesquisa em torno desse tráfico e seu desenvolvimento atual. A intenção reside em apresentar um histórico dos conceitos propostos para a análise do problema e descrever os tratados internacionais existentes, bem como analisar as recomendações de políticas públicas. Destaca-se que a literatura de tráfico internacional de seres humanos está correlacionada com outros conceitos - como crime organizado e compliance.

O trabalho está organizado em quatro seções enquanto a primeira possui três subdivisões, as quais são compostas por uma introdução seguida de uma apresentação dos conceitos centrais para a compreensão do campo de pesquisa sobre o tema, na sequência aborda-se a metodologia pela qual as publicações levantadas foram selecionadas. Na terceira subseção é realizada uma síntese analítica da literatura trabalhada referente ao tráfico de pessoas e como tem sido seu avanço teórico-metodológico. 
Na segunda seção discorre-se acerca do histórico da formação do objeto de análise e como se deu o seu desenvolvimento ao longo do tempo, sendo expostas algumas formas de segmentar a literatura.

A terceira seção está dividida em duas partes. Na primeira, são examinadas quais as bases dos tratados internacionais que tratam de tráfico internacional de pessoas, indicando que há nesses uma ênfase voltada para a produção de políticas públicas. Ainda nesta seção é possível identificar duas principais visões sobre o problema do tráfico de pessoas: a primeira vertente da literatura enfatiza que o enfrentamento ao tráfico de pessoas deve ser baseado em políticas públicas com foco no sistema de justiça criminal; já a outra coloca o foco da discussão na perspectiva dos Direitos Humanos.

A segunda subseção discute o diálogo da literatura de tráfico humano e o conceito de compliance, apresentando trabalhos que seguem essa linha de pesquisa. O final dessa subseção arrola alguns indicadores relacionados à questão do compliance dos países com os tratados de tráfico internacional de pessoas.

A quarta e última seção traz uma breve conclusão das análises realizadas ao longo deste trabalho à luz dos conceitos e da agenda de pesquisa que se formou em torno do tema.

\subsection{FONTES E CRITÉRIO}

O tema proposto neste trabalho é uma discussão acerca da literatura do tráfico internacional de pessoas. A pesquisa foi dividida em subtemas para que, dessa forma, a temática se tornasse mais detalhada e explicativa.

Fatores limitantes, o tempo e os recursos, fizeram com que a revisão teórica fosse a abordagem mais indicada e assertiva para este trabalho. A classificação e divisão desta revisão foram balizadas pela produção existente levantada, levando em consideração a forma como o conhecimento tem sido organizado. Tendo em vista a natureza incipiente da literatura comparada deste tema a produção no geral ainda é baixa, apesar de o levantamento realizado ter buscado se pautar nas publicações mais relevantes de suas respectivas áreas. Outro ponto a se ressaltar diz respeito à natureza da bibliografia refletida neste trabalho em que foram 
consultados diversos trabalhos, incluindo alguns de revisão literária e mesmo relatórios governamentais, para compor a base de reflexão sobre o tema proposto.

Como referencial teórico, além da literatura referente ao tráfico de pessoas, foram levados em conta trabalhos nos quais o conceito de compliance estivesse presente, pois se trata do processo de estudo que, por sua vez, ajuda na compreensão do fenômeno do tráfico internacional de pessoas e seus desdobramentos como, por exemplo, as políticas públicas desenvolvidas. Por isso, elegeu-se essa metodologia por contemplar este conceito.

Primeiramente, faz-se necessário uma breve introdução a este conceito, seu significado e termos correlatos a sua área temática. Assim, parte-se da definição de compliance "as a state of conformity or identity between an actor's behavior and a specified rule" (SLAUGHTER; RAUSTIALA, 2002, p. 539). Sem, contudo, relegar outro conceito importante: o enforcement, que pode ser compreendido como a capacidade que um sistema possui de obrigar com que os acordos estabelecidos sejam de fato cumpridos (ZILBERSZTANJN; SZTAJN, 2005, p. 105).

O estudo de compliance com tratados internacionais teve forte impulso no início de 1990, quando um grupo de autores acreditava que as transformações trazidas pelo fim da Guerra Fria tornariam o direito internacional capaz de constranger e moldar o comportamento dos Estados (BRADFORD, 2004).

Ao analisar a literatura temos que, de acordo com o direito internacional, os direitos e obrigações legais ocorrem entre os Estados. O tratado representa um acordo entre Estados, significa, portanto, um compromisso assumido entre esses entes a fim de direcionar suas condutas futuras, cujo objetivo é afetar o comportamento de um grupo de Estados tanto no presente quanto no futuro. Esta simples relação entre acordo e postura, existia e continua a existir para muitos tratados em âmbito internacional (CHAYES; CHAYES, 1993).

Para a investigação e análise do campo teórico a ser pesquisado e trabalhado, uma série de palavras-chave e termos foram introduzidos em diversos mecanismos de buscas e redes acadêmicas online com o intuito de identificar publicações e materiais secundários relacionados à questão do tráfico de pessoas e ao conceito de compliance. ${ }^{1}$

\footnotetext{
${ }^{1}$ A revisão online considerou termos de busca como "Tráfico internacional de seres humanos"; "Compliance com tratados internacionais"; "Tratados internacionais de tráfico de pessoas"; "Compliance e enforcement com tratados internacionais"; "Compliance e crime organizado transnacional"; "Tráfico internacional de pessoas";
} 
O resultado foi a combinação no presente estudo de diferentes tipos de publicações encontrados, sejam artigos, revisões bibliográficas, capítulos de livros ou dissertações. Notarse-á pela fusão a opção por estudos no espaço de tempo que abrange, principalmente - mas não exclusivamente - da década de 90 até os trabalhos atuais, permitindo assim melhor análise do material e contextualização da realidade. Para uma melhor análise das publicações levantadas gerou-se um quadro resumido dos trabalhos que foram levantados e priorizados para que fizessem parte da revisão bibliográfica (Apêndice A).

\subsection{BALANÇO SOBRE A PRODUÇÃO DO TEMA}

Ainda que o objeto de análise não seja um fenômeno novo e exista uma literatura mais extensa com a temática de escravidão, a forma como os trabalhos publicados sobre tráfico humano veem essa nova forma de escravidão ${ }^{2}$ é eminentemente nova, sendo aqui considerada como uma literatura distinta da literatura sobre escravatura. Um dos principais resultados encontrados diz respeito ao fato de que grande parte dos trabalhos desenvolvidos possui natureza qualitativa. Pode-se atribuir isto, em parte, à natureza ilícita do fenômeno e à dificuldade de sua mensuração. A ilegalidade do fenômeno combinada à insipiência de indicadores confiáveis ao redor de todo o mundo fazem com que o desenvolvimento de trabalhos quantitativos se mostrem restritos e de confiabilidade limitada.

Os autores Frank Laczko e Marco Gramegna (2003) dedicaram-se em um de seus artigos ao exame da questão de tentativas de sinalização de melhores práticas no desenvolvimento de indicadores de tráfico humano mais confiáveis. Parreñas, Hwang e Lee (2012) apontam que, devido a essa questão de confiabilidade dos dados, um expressivo número de literatura relacionada ao tráfico de pessoas está longe de desenvolver um consenso entre os diversos autores que se debruçam sobre o tema. Embora não torne o trabalho inviável, restringe o desenvolvimento de trabalhos quantitativos em larga escala.

\footnotetext{
"Tratados internacionais e crime organizado"; "Compliance e tráfico internacional de pessoas"; "Tráfico humano"; e ainda outras palavras (todas estas foram inseridas nos campos de busca em múltiplas línguas). Foram utilizadas como fontes de bancos bibliográficos diversas bases de dados relevantes para o tema. Recorreu-se a ferramenta do Sistema Integrado de Bibliotecas da USP, bem como a base bibliográfica Journal Storage (JSTOR) e do Social Science Research Network.

${ }^{2}$ Para mais informações ver: BALES, K. Ending Slavery: How We Free Today's Slaves. CALIFORNIA: UNIVERSITY OF CALIFORNIA PRESS, 2007.
} 
Observando com mais profundidade a questão da coleta de dados nesta temática, vê-se a indicação do relator especial da ONU sobre tráfico de pessoas de que "Overall, less than 30 per cent of trafficking cases is reported to the officials, both in cases of internal and crossborder trafficking." (EZEILO, 2009, p. 11). Neste sentido, pode-se apontar que algumas das possíveis razões para a questão da dificuldade da coleta de dados podem ser: a) A natureza escusa e ilegal do tráfico; b) A falta de legislação antitráfico em muitos países; c) A relutância das vítimas em relatar as suas experiências para as autoridades; d) A falta de prioridade do governo dada à coleta de dados e pesquisa (IOM, 2007, p. 1).

Ao se analisar a literatura, é possível apontar um avanço teórico-metodológico com a presença de produções sólidas e maduras. Tendo em vista o recente desenvolvimento dos estudos de tráfico de pessoas voltado para a orientação de políticas públicas, entende-se ser natural que esta literatura não tenha sido exaustivamente trabalhada, propiciando, por isso, espaço para avanços.

\section{A CONSTRUÇÃo dA ÁREA TEMÁTICA dO TRÁFICO HUMANO}

A literatura de tráfico internacional de pessoas, como já colocado, é considerada nesse trabalho distinta daquela que discorre sobre a escravidão. Analisa-se, então, a literatura que lida com um fenômeno que, apesar de em sua essência não ser novo - o aprisionamento e a exploração de outro ser humano - possui uma nova abordagem de estudos, com relevantes elementos distintos daqueles sobre os quais se concentravam e se analisavam ao tratar da escravidão desde o século XVII até o início do século XX.

Apenas para servir como um referencial, segue a defesa desta linha por um dos autores. Essa defesa se enquadra, de maneira mais generalizada, no âmbito do direito internacional da literatura de acordos entre Estados com a temática do tráfico de pessoas.

Instruments that have dealt with human trafficking date back to the abolition of slavery. They include provisions within the Slavery Convention (1926) and the Supplementary Convention on the Abolition of Slavery, the Slave Trade, and Institutions and Practices Similar to Slavery (1956). Additional tools of international law that include segments against the trafficking of persons include: the Universal Declaration of Human Rights (1948), the International Covenants on Civil and Political Rights (1966), The United Nations Convention for the Suppression of the Traffic in Persons and of the Exploitation of the Prostitution of Others (1949), and 
the Convention on the Elimination of all Forms of Discrimination Against Women (1979). These instruments laid the foundation for the contemporary conventions and efforts to eliminating trafficking. (KING, 2008, p. 1)

Quando o histórico do combate ao tráfico humano é analisado sob a ótica específica dos Direitos Humanos, há também a inclusão de outro instrumento internacional, ou seja, os Princípios e Diretrizes Recomendadas Sobre Direitos Humanos e Tráfico de Pessoas, apresentados pelo Alto Comissariado das Nações Unidas para os Direitos Humanos ao Conselho Econômico e Social, no ano de 2002. Esse documento destaca a importância dos direitos das pessoas traficadas e todos os esforços e medidas adotadas para prevenir e combater o tráfico de seres humanos, assim como a atenção necessária às vítimas. Além de defender que medidas de enfrentamento ao tráfico de pessoas não devem atingir os Direitos Humanos e a dignidade das pessoas afetadas, particularmente os direitos das pessoas traficadas e de migrantes, pessoas deslocadas internamente, refugiados e pessoas em busca de asilo (PIOVESAN; KAMIMURA, 2013, p. 114).

Como se pode perceber, a questão do tráfico de pessoas tem permeado todo o direito internacional do último século. O mais recente e mais importante instrumento internacional que trata de tráfico de pessoas é a Convenção das Nações Unidas contra o Crime Organizado Transnacional e seus dois protocolos (que ficaram conhecidos como Protocolos de Palermo): o Protocolo das Nações Unidas para Prevenir, Suprimir e Punir o Tráfico de Pessoas, especialmente Mulheres e Crianças; e o Protocolo das Nações Unidas contra o Contrabando de Migrantes por Terra, Mar e Ar, que entraram em vigor em 2003-2004. Todos criados e arquitetados pelo Escritório das Nações Unidas sobre Drogas e Crime tendo apoiado a capacidade do direito internacional para combater o tráfico de seres humanos (THE GLOBALIZATION OF CRIME, 2010, p. 39).

Ao se observar a criação deste tratado internacional por meio da literatura de compliance, encontram-se alguns autores que defendem a tese de que um dos motivos que facilitaram a aceitação da Convenção de Palermo e seus Protocolos foi por entenderem que conseguiram cooperar com este tratado e seguiriam as regras impostas por estes sem desviar do curso de ações que inicialmente tomariam. Assim, sendo compliance pode ser entendido como o estado de conformidade, o qual o ator estatal possui com a norma da Convenção de 
Palermo. Portanto, entende-se que a referida convenção foi aceita pela comunidade internacional por este perceber que o curso de suas ações já estava alinhado, em alguma medida, com as diretrizes impostas por este tratado internacional. Autores condizentes com esta linha de raciocínio asseguram que os Estados tendem a buscar negociação apenas com acordos internacionais que irão de fato cumpri-los. Downs, Rocke e Barsoom abrangem bem esse ponto quando comentam:

\footnotetext{
States choose the treaties they make from an infinitely large set of possible treaties. If some treaties are more likely to be complied with than others or require more enforcement than others, this will almost certainly affect the choices states make. $[\ldots]$ states will rarely spend a great deal of time and effort negotiating agreements that will continually be violated. (DOWNS; ROCKE; BARSOOM, 1996, p. 383)
}

Indubitavelmente, pode-se concluir que todos esses instrumentos legais internacionais foram fundamentais para $\mathrm{o}$ condicionamento da produção de novas análises $\mathrm{e} \quad \mathrm{o}$ desenvolvimento desse escopo de estudo. Porém, não existe consenso entre os pesquisadores acerca do foco que deve se dar. A amplitude da definição no Protocolo de Palermo e a ênfase em exploração sexual são partes do porquê destas visões distintas. Como já mencionado, um fator fundamental que contribui para a falta de consenso diz respeito à questão de dados confiáveis. Segundo o UNODC que compartilha a visão de que "It is very difficult to assess the real size of human trafficking because the crime takes place underground, and is often not identified or misidentified." (KEMPADOO, 2005, apud PARREÑAS; HWANG; LEE, 2012, p. 2).

Esse estudo da temática de tráfico de pessoas baseou-se nos autores Parreñas, Hwang e Lee (2012), que agrupam tematicamente em três linhas os estudos de tráfico humano: 1. O exame das Leis e suas funções no esforço ao combate ao tráfico humano ${ }^{3}$ (linha que o presente trabalho focou o balanço da literatura); 2. Documentos acerca do tráfico humano no período contemporâneo ${ }^{4} ; 3$. E o reenquadramento do tráfico como uma questão de trabalho ${ }^{5}$.

No entanto, no contexto do presente trabalho e tendo em conta o levantamento de produção bibliográfica desenvolvido, foram priorizados - para a demonstração das duas

\footnotetext{
${ }^{3}$ Para mais informações ver: Scarpa (2008), Doezema (2010), Li-Moncelli (2010).

${ }^{4}$ Para mais informações ver: Bales (2007) Bales e Trodd (2008) e Kara (2009).

${ }^{5}$ Para mais informações ver: Kempadoo (2005).
} 
principais abordagens de políticas públicas na matéria de tráfico internacional de pessoas - os trabalhos de Chuang (2006), Laczko e Gramegna (2003), o de Trodes (2011) e Piovesan e Kamimura (2013).

\section{AVANÇOS E LACUNAS DO OBJETO EM ANÁLISE}

Ao desenvolver a revisão bibliográfica, o traço crucial consiste no fato de que a literatura de tráfico de seres humanos nos últimos anos tem tomado ainda mais relevância como status analítico próprio, deixando de ser apenas apêndice de outros fenômenos analisados em paradigmas gerais e fontes de referência.

O objeto de estudo passou por mudanças ao longo do desenvolvimento de sua literatura. Ainda que tratado com singularidade, os autores ao abordarem essa temática ilícita, buscam a generalização e não a especificação (ainda que existam estudos de casos que focalizem em um recorte específico, como exemplificado ao final deste trabalho). Os estudos específicos sobre compliance e acordo internacional em relação ao tráfico humano ou de casos de tráfico de pessoas em um país ou região existem e têm se proliferado. Contudo, essas duas áreas - estudos sem um recorte geográfico específico e trabalhos que estudem um país em última análise, agregam-se aos estudos acadêmicos e científicos da área e, de uma forma geral, tentam explicar fenômenos que, embora distintos, são correlatos.

Mais adiante algumas publicações, como a referência de Lindsey King e seu artigo International Law and Human Trafficking (2008), serão importantes para um panorama geral - apesar de genérico - de como as pontas de direito internacional, sua abordagem de compliance e tratados e tráfico de pessoas se unem.

Entretanto, também fica evidente que se trata inequivocamente de um debate novo. Assim, devido a baixa produção e generalizações feitas pelos autores que se propõem a fazer essa ponte, ainda existem muitas lacunas a serem trabalhadas e barreiras a serem transpostas quando se trata das literaturas de tráfico de pessoas e o compliance com seus tratados internacionais. 


\subsection{TRÁFICO INTERNACIONAL DE PESSOAS}

O tráfico internacional de seres humanos é um fenômeno que pode ser contextualizado dentro do avanço e desenvolvimento do crime organizado transnacional. Tendo o crime organizado como plano de fundo, foi a partir dos anos 90 que esse tipo de crime transnacional se expandiu, auferindo além de lucros econômicos, força política sem precedentes. Força esta que influencia fortemente a dinâmica local onde estão baseadas as células criminosas, exercendo pressão direta ou indireta sobre os sistemas nacionais de segurança pública de diversos países. Segundo Naím (2005), as lentes utilizadas para entender a política e a economia mundial devem ser ajustadas devido à magnitude que o crime organizado transnacional tem tomado nas últimas décadas. Nas palavras do autor:

\footnotetext{
Por trás da ascendência política das redes criminosas globais está uma dinâmica de globalização poderosa, ainda que geralmente menosprezada. [...] as mudanças da década de 1990 não apenas fortaleceram os criminosos, como, ao mesmo tempo, enfraqueceram as instituições encarregadas de combatê-los. O sucesso das redes criminosas baseia-se tanto na mobilidade internacional como em sua habilidade de se beneficiar das oportunidades brotadas da separação dos mercados e que desaguaram dentro das fronteiras dos Estados soberanos. Para os criminosos, as fronteiras criam oportunidades de negócios e escudos convenientes; no entanto, para os funcionários do governo que os caçam, as fronteiras são frequentemente obstáculos intransponíveis. Os privilégios da soberania nacional transformam-se em fardos e limitações para os governos. Devido a essa assimetria, no confronto global entre governos e criminosos, os governos sistematicamente saem perdendo. Em toda parte. (NAÍM, 2005, p. 18).
}

Vê-se então que a influência que o crime organizado começou a exercer sobre governos não pode ser subestimada. As políticas públicas de diversos países tiveram de empenhar-se ainda mais, fazendo rearranjos, inclusive, desenvolvendo novas competências para combater as atividades ilícitas que não se intimidavam com as fronteiras nacionais.

Apesar de o tema ser reconhecido pelo direito internacional como um problema desde o início da década de 90 , por quase todo o século XX o tráfico era considerado uma esfera limitada que concernia principalmente mulheres, sendo assim, objeto de análise apenas pelo sistema internacional de Direitos Humanos. Foi com o início do movimento pelos direitos femininos, no inicio da década de 90, que a atenção para a questão do tráfico foi levantada. Simultaneamente estava ocorrendo outro fenômeno, o do início da migração de trabalhadores 
em massa. A conjunção destes diversos fatores fez com que os governos e as instituições internacionais começassem a desenvolver uma consciência coletiva do papel que o crime organizado transnacional estava tomando (CHUANG, 2006). O resultado foi uma espiral de crescente interesse, desvendando que o fenômeno atingia homens, mulheres e crianças, para propósitos sexuais e não sexuais, incluindo a exploração do trabalho industrial, trabalho doméstico, trabalho rural, e outras formas de exploração análogas à escravidão.

A então existente lei internacional em tráfico - A Convenção da ONU para a Supressão do Tráfico de Pessoas e a Exploração da Prostituição de Outros $^{6}$ (de 1949) endereçava apenas o tráfico para fins sexuais. De acordo com Chuang (2006), governos ao redor do mundo consentiam que suas estruturas domésticas legais eram fracas para processar e julgar culpados, e de prover meios apropriados de proteger as vítimas.

Ao se analisar a literatura pode-se apontar a convergência de opiniões diante do fato de que um novo aparato legal era necessário para a coordenação global e a resposta para esse problema transnacional. Os autores Naím (2005) e Chuang (2006) dialogam entre si ao concordarem que as políticas públicas vigentes e o aparato legal que os estados nacionais possuíam não eram adequados para a nova ameaça que o crime organizado mundial apresentava. Nesse contexto surgiu a oportunidade de tratar a questão do crime organizado e do tráfico humano por meio da Convenção contra o Crime Organizado Transnacional e de seus Protocolos específicos, sendo este o primeiro tratado a abordar a questão do crime transnacional de maneira sistemática. Os Estados Unidos introduziram o primeiro rascunho do protocolo em janeiro de 1999, e, em menos de dois anos depois, a Assembleia Geral da ONU votou e adotou a Convenção e seus Protocolos (CHUANG, 2006).

Esta Convenção foi então complementada por três protocolos que abrangem áreas específicas do crime organizado: o Protocolo Relativo à Prevenção, Repressão e Punição do Tráfico de Pessoas, em Especial Mulheres e Crianças; o Protocolo Relativo ao Combate ao Tráfico de Migrantes por Via Terrestre, Marítima e Aérea; e o Protocolo contra a fabricação e

\footnotetext{
6 Texto na íntegra disponível em: <https://treaties.un.org/doc/Publication/UNTS/Volume\%2096/v96.pdf.> O texto do tratado inicia-se na página 272. Acesso em 20 mar. 2014.
} 
o tráfico ilícito de armas de fogo, suas peças e componentes e munições. Observa-se que os países devem ratificar a Convenção antes de aderir a qualquer um dos protocolos ${ }^{7}$.

O Protocolo endereçado especificamente ao tráfico humano leva os dizeres essenciais que se fundamentam no enfrentamento ao tráfico de pessoas no entendimento das Nações Unidas e os Estados que assinaram o acordo. O combate a essa prática ilícita deve ser baseado no tripé de políticas públicas que contemplam a prevenção, repressão e punição. Essa necessidade tríplice de ações conjuntas e simultâneas, juntamente com a proteção às vítimas, também é reforçada no próprio Protocolo:

Declarando que uma ação eficaz para prevenir e combater o tráfico de pessoas, em especial mulheres e crianças, exige por parte dos países de origem, de trânsito e de destino uma abordagem global e internacional, que inclua medidas destinadas a prevenir esse tráfico, punir os traficantes e proteger as vítimas desse tráfico, designadamente protegendo os seus direitos fundamentais, internacionalmente reconhecidos (...) (ONU, 2000, p. 344, grifo nosso).

Outro ponto interessante deste protocolo sob o prisma da literatura de compliance reside na questão de enforcement. O Protocolo de Palermo não especifica nenhum mecanismo e, por extensão, permite que não haja nenhum sistema de monitoramento de seu cumprimento. Isso fica evidente quando se averigua a seguinte passagem:

Currently, there are no mechanisms in place to determine whether state parties have properly implemented the Protocol. This absence of oversight leaves the Protocol without the power to monitor whether state parties are adhering to its provisions and to enforce them if they are not. (HENDRIX, 2010, p. 182)

Tendo em vista ainda a questão do enforcement sob a ótica da literatura de compliance pode-se colocar que alguns autores ${ }^{8}$ apresentam o conceito de que o compliance dos Estados com acordos internacionais embora seja normalmente bom, o enforcement é inócuo visto que representa pouco ou nenhum papel para atingir ou manter seus objetivos. Convém lembrar que baseado em parte da literatura de compliance, os construtores do Protocolo de Palermo

\footnotetext{
${ }^{7}$ Texto na íntegra disponível em: <http://www.unodc.org/lpo-brazil/pt/crime/marco-legal.html> Acesso em: 23 mar. 2014.

8 Autores que defendem a linha do "managerial thesis", dentro da literatura de compliance. Para mais informações sobre as diferentes correntes dentro desta literatura e um foco maior na tese managerial ver DOWNS, G. W.; ROCKE, D. M.; BARSOOM, P. N. Is the good news about compliance good news about cooperation?. International Organization, n. 50, v. 3, p. 379-406, 1996.
} 
ponderaram que inserir mecanismos de enforcement iria trazer pouco efeito real na mudança do comportamento dos Estados membros.

Depois de aprovada em 15 de novembro de 2000, e de acordo com o seu parágrafo $3^{\circ}$, a Convenção das Nações Unidas contra o Crime Organizado Transnacional estabeleceu como definição de tráfico de pessoas:

\begin{abstract}
A expressão "tráfico de pessoas" significa o recrutamento, transporte, transferência, abrigo ou recebimento de pessoas, por meio de ameaça ou uso da força ou outras formas de coerção, de rapto, de fraude, de engano, do abuso de poder ou de uma posição de vulnerabilidade ou de dar ou receber pagamentos ou benefícios para obter o consentimento para uma pessoa ter controle sobre outra pessoa, para o propósito de exploração. (ONU, 2000, p. 344)
\end{abstract}

Infere-se, então, que tráfico seria um termo guarda-chuva englobando múltiplas ações que juntas podem ser vistas como um processo com distintas abordagens: 1) o recrutamento e transporte de pessoas; 2) por meio de fraudes, uso da força ou coerção; 3) para fins de exploração. ${ }^{9}$

A ótica dos Direitos Humanos analisa a questão dos fins de exploração com especial atenção ao elencar como formas mais comuns de aliciamento para a exploração sexual e o tráfico as falsas ofertas de emprego, promessas de vida melhor e de casamento. A violência intrafamiliar e extrafamiliar constitui também um fator de vulnerabilidade que favorece o ingresso da criança e da adolescente nas redes de exploração sexual comercial e de tráfico (PIOVESAN; KAMIMURA, 2013, p. 111).

O objeto de análise, por sua natureza ilegal e difusa, do ponto de vista de políticas públicas e de ações legais se mostra ainda mais complexo, haja vista a possibilidade de que cada ação pode ativar outras questões legais relacionadas - como imigração e a legislação criminal (CHUANG, 2006). Em corroboração com essa linha de raciocínio, Laczko e Gramegmna (2003) dialogam com Chuang ao apontarem que:

Trafficking in persons is used as an umbrella term to cover a range of actions and outcomes. Viewed as a process, trafficking can be said to entail several phases recruitment, transportation (which could be across several countries), and control in the place of destination. Different groups, agents or individuals may be involved in different phases of the process, and can organize recruitment, transportation and control in different ways. There is thus immense diversity between and within

\footnotetext{
${ }^{9} \mathrm{O}$ conjunto destas ações se mostra relevante no momento de desenvolvimento de base de dados, em que três condições devem ser atendidas para tipificar um crime como tráfico humano. O Human Trafficking Case Law Database - enunciado mais adiante neste trabalho - baseia-se nestas premissas.
} 
trafficking systems. (O'CONNELL; DAVIDSON; DONELAN ${ }^{10}$, 2003, apud LACZKO; GRAMEGNA, 2003, p.181)

Ao avaliar o diálogo entre os autores é possível assinalar que a atividade ilícita do tráfico de pessoas se distancia de outros ilícitos transnacionais, como o contrabando de armas. O crime em análise se aproxima, em sua natureza, de ilicitudes como o sequestro, em que o crime não é cometido em único ponto no espaço-tempo, tornando as possíveis diretrizes de políticas públicas a serem tomadas ainda mais complexas. Examina-se a partir de então que os autores começam a tomar posições sobre qual deve ser o foco de análise das políticas públicas dos Estados: punição e repressão ou prevenção.

Os autores Chuang (2006) e Laczko e Gramegna (2003) também concordam em relação à ótica que possuem de como um enfrentamento eficiente à atividade ilegal do tráfico deve ser elaborada. Esses autores dão maior ênfase a um dos pilares do tripé do Protocolo de Palermo, ou seja, a punição aos criminosos, visto que, para estes, o sistema criminal deve ser o foco das políticas públicas.

Tão complexo quanto esse assunto da perspectiva legal e conceitual, o tráfico fica ainda mais difícil de ser resolvido no aspecto político. De acordo com Chuang (2006), existem duas vertentes que dividem em lados opostos opiniões acerca do tráfico: de um lado estão os abolicionistas, que acreditam que toda forma de prostituição é exploradora e degradante, não fazendo distinção entre a voluntária e a forçada. Do outro lado estão aqueles que acreditam que as mulheres podem escolher o sexo como profissão e um meio viável de vida. Durante as negociações para a definição de tráfico no processo de Viena (como ficaram conhecidas as negociações para o Protocolo de Palermo) foram altamente faccionadas: um grupo de Estados adotando a perspectiva abolicionista enquanto outros adotaram a posição que incluía a migração por não coerção para trabalhos sexuais - esses últimos apoiados pela ONU.

Ainda segundo essa autora, outra questão, concernente ao desenvolvimento da literatura, discutida durante o processo de Viena foi a tensão entre enquadrar o combate ao tráfico como um assunto criminal e de controle ou como questão de Direitos Humanos, já dando indícios desde então da dicotomia em relação ao enfrentamento ao tráfico humano iria

\footnotetext{
${ }^{10}$ Para mais informações ver: DAVIDSON, J. O.; DONELAN, B. Review of the Evidence and Debates on the Demand Side of Trafficking. Stockholm: Save the Children, 2003.
} 
se colocar. Muitos membros da comunidade de Direitos Humanos ficaram desapontados com o fato de que o primeiro instrumento legal referente ao tráfico humano tenha sido elaborado pela Comissão de Crimes das Nações Unidas e não pela Comissão de Direitos Humanos (CHUANG, 2006).

Para Laczko e Gramegna (2003), os elaboradores do Protocolo de Palermo foram bem-sucedidos ao estabelecer uma estrutura internacional de cooperação para a punição do crime, para coordenar uma resposta transnacional para esse problema global e complexo. Para esses autores a Convenção das Nações Unidas contra o Crime Organizado em conjunto com seus protocolos estabeleceram medidas concretas para melhorar a comunicação e a cooperação entre as autoridades nacionais responsáveis pelo cumprimento da lei, engajandoos em assistências mútuas, facilitando extradições e estabelecendo investigações bilaterais e multilaterais. Os referidos pesquisadores baseiam seus argumentos nos mecanismos compreendidos na Convenção Contra o Crime Organizado, pois, ao reconhecer que alguns países em desenvolvimento não têm a capacidade de implementar as medidas necessárias, a convenção obriga aos Estados desenvolvidos a cooperarem e proverem assistências técnica e material para que a Convenção seja seguida por todos os membros (ONU, 2000).

Pondera-se, portanto, que parte do debate está estabelecido, considerando-se que os autores citados até então se pronunciaram em prol de um sistema internacional no qual as políticas públicas fundamentam-se na repressão ao tráfico humano e na punição dos criminosos que o praticam. Para Lacko e Gramegna (2003), incluindo Chuang (2006), o sistema penal é a base de políticas públicas bem estruturadas na defesa da segurança humana, no que concerne ao tráfico de pessoas.

Do outro lado do debate, no avanço da literatura sobre tráfico internacional de pessoas também há autores que acreditavam que o caminho para uma melhor solução não se dá apenas com a efetivação de uma legislação forte, sendo complementada pelo enforcement e compliance. Isto é, existem outros autores que não apostaram no sistema criminal como forma efetiva de combater a esta prática ilícita. Como será demonstrado, há o surgimento de outra linha de pensamento que conflita com o foco em sistemas de justiça criminais. O debate assim se estabelece na medida em que se muda o foco para a perspectiva da defesa dos Direitos Humanos ao tratar da questão do tráfico internacionais de pessoas, colocando-o em outro pilar do tripé do Protocolo de Palermo, quer dizer, a prevenção ao tráfico. 
Cabe ressaltar que o fato de haver maior ênfase dos autores em prol do sistema de justiça criminal à repressão e punição e da vertente dos Direitos Humanos à prevenção, não implica que os sistemas de justiça criminal não atuem sob aspectos preventivos e que a perspectiva de Direitos Humanos não apoie determinadas ações de repressão e punição. A análise realizada por meio deste artigo diz respeito à ênfase dada por cada uma dessas vertentes.

O autor Jonathan Trodes, em um artigo publicado pela Legal Studies Research (Georgia State University College of Law), de 2011, Moving Upstream: The merits of a public health law approach to human trafficking, pode ser enquadrado na ala dos defensores de que as políticas públicas não devem se fixar nos esforços empreendidos apenas pela legislação criminal.

(...) have taken significant steps to combat human trafficking. Their approach has been driven largely by a criminal law framework, and the cumulative result of their efforts is a patchwork of criminal laws and some assistance programs for victims, but almost no measures addressing the root causes of the problem. More important, although measuring the success of interventions to date is challenging given the clandestine nature of human trafficking and other constraints, there is no evidence to suggest that human trafficking is declining. This lack of meaningful progress prompts questions as to what the best framework would be for addressing this issue. (TRODES, 2011, p. 6)

Como se pode notar, o autor critica a abordagem que para o efetivo combate ao tráfico humano se deveria investir apenas na legislação criminal. Desse modo, rivaliza o debate ao defender a posição de que a adequada defesa contra essa atividade ilícita estaria centrada na confrontação das raízes do problema. O trabalho de Trodes (2011) assegura que, devido ao fato das estratégias centradas no compliance com as leis referentes ao tráfico humano não estarem funcionando - por estarem centradas na punição e repressão -, é necessária uma nova perspectiva para o problema. Essas iniciativas - de acordo com o autor - apesar de serem importantes em muitos aspectos não nos trouxeram mais próximos do objetivo final de fazer com que o crime seja minimizado, ou mesmo eliminado.

Assim, para o autor, uma abordagem inovadora e exploratória do problema do tráfico humano seria a visão da temática sob as lentes distintas da saúde pública. Normalmente questões de saúde pública objetivam identificar potenciais causadores de dano à população e identificar as causas desse a fim de prevenir que este ocorra. O cerne dos estudos na área da saúde pública dirige-se para ações preventivas capazes de alcançar às vítimas potenciais antes 
que os traficantes o façam. Segundo o autor, a abordagem da saúde pública também vai além do reduzido foco das leis criminais em apontar um culpado/perpetrador para atingir também a comunidade como um todo: "This limitation of the criminal law framework calls for new approaches, because continuing on this current path dooms us to an endless cycle of chasing perpetrators and seeking to help individuals after they have been exploited." (TRODES, 2011, p. 9).

Visualizar o tema do enfrentamento ao tráfico de seres humanos com a perspectiva de políticas públicas de saúde sugere passos diferentes a serem tomados. Por exemplo, o sistema criminal deixaria de ser a instituição central da política pública na defesa contra o crime, mas não se extinguiria, sendo uma instituição complementar a todo um sistema centrado na busca de soluções que se dirijam às vulnerabilidades das vítimas antes que o crime seja cometido. Dessa forma, faz com que o sistema de repressão e punição seja acionado apenas em poucos momentos. Por meio da análise desta literatura é possível observar que embora essa abordagem de saúde pública não seja suficiente, a metodologia utilizada pode ajudar nos esforços antitráfico.

Também há outros autores que defendem a vertente preconizada pela perspectiva dos Direitos Humanos. Piovesan e Kamimura (2013) afiançam que é fundamental que o eixo central de toda e qualquer intervenção seja o devido cumprimento e promoção dos Direitos Humanos, especialmente em relação às pessoas traficadas, considerando-se as particularidades e vulnerabilidades específicas de cada pessoa. Para a incorporação e a aplicação de uma perspectiva de Direitos Humanos e gênero, é imprescindível que em cada medida planejada e em cada intervenção a ser implementada no enfrentamento ao tráfico de pessoas seja afirmada a dignidade e evitado o sofrimento humano.

Os direitos humanos devem assumir especial centralidade a orientar todos os programas, ações e medidas para prevenir e combater o tráfico de seres humanos, bem como para proteger e reparar suas vítimas, considerando ser o tráfico de pessoas causa e consequência de graves violações a direitos (PIOVESAN; KAMIMURA, 2013, p. 119).

Conclui-se então que a visão que Trodes (2011) e Piovesan e Kamimura (2013) seguem uma vertente distinta de outros autores apresentados neste trabalho, dando maior importância à perspectiva dos Direitos Humanos nos mecanismos de enfrentamento ao tráfico de pessoas. Estes são os principais pontos com que rivalizam estes autores - entendendo o 
enfrentamento ao tráfico humano sob esta outra óptica, ou seja, mais exclusivo na necessidade de atacar a raiz do problema, por meio da prevenção - e outros autores como Chuang (2006) e Laczko e Gramemna (2003) - acreditam que o sistema de justiça criminal, voltado em sua natureza na repressão e punição, é a forma mais eficaz de combater o tráfico de seres humanos.

Contudo, independentemente da abordagem seguida ou da ótica desejada, há lacunas a serem transpostas por toda a literatura do objeto de análise. Assim, como lacuna do desenvolvimento da teoria, pode-se colocar que, além do baixo índice de publicações específicas e a falta de um maior diálogo entre os autores, há também a problemática de padronização metodológica para o estudo do tema, bem como o levantamento e criação de dados confiáveis para que acadêmicos se apropriem e desenvolvam suas publicações, tanto com vieses quantitativos quanto qualitativos.

Um dos pontos centrais é o fato de que pela natureza do tráfico humano, este se enquadra como um crime sub-reportado, no qual a maioria dos casos permanece não revelados. Outro aspecto é o relativo novo fôlego - se se considerar a perspectiva histórica que o tema tem tido, pois o tema recebia pouca atenção desde o início do século XX. Isso decorre por dois principais motivos: primeiro, uma legislação fraca e inadequada, ou ainda não implementada, fazendo com que o julgamento de culpados seja difícil; segundo, a condenação normalmente se dá por testemunho da vítima, e tal testemunho muitas vezes é custoso de obter (LACZKO; GRAMEGMNA, 2003).

Em estudos conduzidos no Reino Unido, ${ }^{11}$ em 1999, foram encontradas evidências de que o nível de prioridade que as polícias locais davam ao combate ao tráfico de pessoas possuía impacto na produção de dados - se eram produzidos ou não. Esse estudo encontrou que dados de tráfico eram produzidos apenas em locais onde a força policial monitorava a indústria sexual local como parte de seus mandatos no combate a violência, revelando assim a baixa relevância que a produção de dados sobre tráfico de seres humanos possuía nas instituições domésticas britânicas.

\footnotetext{
${ }^{11}$ Para mais informações ver: KELLY, L.; REGAN, L. Stopping Traffic: Exploring the Extent of, and Responses to, Trafficking in Women for Sexual Exploitation in the U.K. London: Home Office, Police Research Series Paper 125, 1999.
} 
Além de serem poucos os governos, ou ONGs, que produzem dados sobre essa questão, aqueles que os produzem não possuem um ponto central para o qual destinem as informações, causando, portanto, a inexistência de uma harmonização das estatísticas. Como cada agência lida com a questão do tráfico internacional de acordo com sua necessidade, há a possibilidade da mesma vítima ser computada mais de uma vez por agências distintas. Outra lacuna relevante consiste na questão de periodicidade, pois, enquanto alguns países desenvolvem a compilação dos dados sobre tráfico humano anualmente, outros o fazem com outro recorte temporal. Para deixar o cenário menos positivo, há o problema do não compartilhamento de dados, ou ao menos, a ausência de circulação na medida em que poderia acontecer. A troca de informações no combate ao tráfico humano é essencial, e um dos problemas é que quando esta ocorre se dá de maneira ad hoc - quando deveria ser permanente (LACZKO; GRAMEGMNA, 2003).

\subsection{TRÁFICO DE PESSOAS E COMPLIANCE COM SEUS TRATADOS INTERNACIONAIS}

Nesta seção serão apresentados alguns trabalhos voltados especificamente para compliance, com o recorte de tratados internacionais sobre tráfico internacional de pessoas. Além de publicações acadêmicas, também há outras em forma de relatório, de ranking e base de dados online que demonstram na prática o comportamento de diversos Estados diante das normas internacionais, isto é, sendo os indicadores de compliance com os acordos que tratam do tráfico humano.

O trabalho de Lindsey King (2008) aponta que o Protocolo da ONU acerca do tráfico de pessoas pode ser considerado como um instrumento único, na medida em que foi criado como um instrumento de enforcement, o que em teoria, dá mais influência do que a outros acordos anteriores. Disposições nesse Protocolo indicam que os Estados membros devem: agir para penalizar o tráfico, proteger as vítimas e garantir as vítimas com residência temporária ou permanente no país de destino desta. Se um Estado, que seja parte da Convenção e de seus Protocolos, possui obrigatoriedade de criar uma legislação que suporte essas questões em âmbito doméstico. 
A autora King busca detalhar dispositivos inéditos contemplados pelo Protocolo de Palermo, haja vista que são estes artifícios que permitem melhor enquadramento do tráfico de pessoas, tornando assim o compliance dos países mais direto. Exemplos destes dispositivos são: a questão de que a pessoa não possui escolha ao ser traficada (colocando-a na posição de vítima); também é assinalado que se uma pessoa é contrabandeada (ou seja, com o próprio consentimento), mas depois for aprisionada, esse crime será considerado como tráfico; outro aspecto refere-se ao fato de a pessoa não possuir meios alternativos senão obedecer à situação, essa ação também constitui tráfico de pessoas (KING, 2008).

King acrescenta que uma das formas de ocorrer um melhor compliance com tratados de tráfico internacional de seres humanos é a regionalização dessas normas globais. Essa abordagem segue o preceito de que o enforcement de leis internacionais se dá mais eficientemente por meio da incorporação na legislação regional e/ou doméstica. Assim, alguns instrumentos regionais e domésticos têm tido posição chave na defesa deste crime: United States Victims of Trafficking and Violence Protection Act (2000), the Council of Europe Convention on Action against Trafficking in Human Beings (2008), e o European Convention for the Protection of Human Right and Fundamental Freedoms (1950) (KING, 2008).

Ao se observar os argumentos colocados pela autora, é possível deduzir que o viés defendido segue a linha de políticas públicas baseadas em repressão e punição, tendo em vista que as legislações citadas encontram-se centradas no sistema criminal. A referida autora concentra seus exemplos no eixo Estados Unidos-Europa, porém há outros esforços regionais fora deste que também merecem ser citados, como o Coordinated Mekong Ministerial Initiative against Trafficking (Commit), um grupo subregional composto pela China, Laos, Tailândia, Camboja, Myanmar e Vietnam, criado em 2005, cujo propósito consiste em desenvolver políticas de combate ao tráfico para a região, permitindo que cada Estado crie sua própria legislação em consonância com o grupo. Em todas essas iniciativas, sejam locais ou regionais, essas normas sempre são criadas em linha, ou seja, seguindo as premissas do acordo internacional de Palermo.

Além dos trabalhos com viés mais acadêmicos publicados, se faz necessária a indicação nesta seção de alguns indicadores que simbolizem a questão do compliance com o tráfico internacional de pessoas. Por conseguinte, há três indicadores representativos dos 
resultados que os países têm alcançado na busca de comply com acordos internacionais que tratem da natureza das atividades ilícitas do tráfico humano.

Uma publicação que desenvolve a relação entre tráfico internacional de pessoas e compliance com normas globais é o Trafficking in Persons Report. ${ }^{12}$ Trata-se de um relatório com periodicidade anual, publicado pelo Departamento de Estado do governo norteamericano, que possui o objetivo de verificar como diversos governos ao redor do mundo têm atuado de forma harmônica com as normas globais estabelecidas. Tendo em vista que os Estados Unidos são a principal economia global e, portanto, um dos países mais afetados por esta forma de crime (principalmente na relação tráfico de pessoas/migrações), possui um forte interesse estatal norte-americano pelo combate deste e para que haja de fato atuação da comunidade internacional em sua prevenção. Dessa forma, a publicação do Trafficking in Persons Report pode ser analisada como um bem público global, pois está alinhada com os preceitos internacional da matéria, alimentando o debate anualmente e demonstrando que os Estados Unidos estão agindo em conformidade com as diretrizes estratégicas da Convenção de Palermo.

Trafficking in Persons Report satisfies a statutory mandate to look closely at how governments around the world are fulfilling their obligations to combat this crime. It emphasizes continued and strong government action as the foundation upon which the fight against modern slavery is built. And it both makes government-specific recommendations, and calls upon the international community as a whole to advance a more robust victim-centered response to this crime (TRAFFICKING IN PERSON REPORT, 2012, p. 8)

Para o desenvolvimento desse relatório a metodologia utilizada pelo Departamento de Estado dos Estados Unidos baseia-se em informações de embaixadas estadunidenses, dados oficiais de governos e de organização não governamentais, artigos acadêmicos, investigações próprias e outros relatórios ${ }^{13}$ (TRAFFICKING IN PERSON REPORT, 2012). Para a classificação dos países, o relatório se utiliza de uma segmentação em camadas - ou Tiers. Enquanto a camada 1 representa o mais alto padrão - ou seja, o país enquadrado nesse ponto chega mais próximo de um compliance exemplar de acordo com os padrões adotados -, a camada 4 representa aqueles países cujos esforços para o enfrentamento ao tráfico de pessoas devem ser intensamente trabalhados. Todavia, em nenhum dos diferentes níveis há um

\footnotetext{
${ }^{12}$ Texto na íntegra disponível em: http://www.state.gov/j/tip/rls/tiprpt/. Acesso em: $1^{\text {o }}$ abr 2014.

${ }^{13}$ Para mais informações acerca da metodologia adotada: http://www.state.gov/j/tip/rls/tiprpt/2014/226645.htm
} 
apontamento da abolição do tráfico, as diferentes camadas são apenas representativas dos esforços em comply na matéria de tráfico internacional de pessoas que os Estados têm buscado.

The Department places each country in the 2013 TIP Report onto one of four tiers (...). This placement is based more on the extent of government action to combat trafficking than on the size of the problem. The analyses are based on the extent of governments' efforts to reach compliance with minimum standards for the elimination of human trafficking (...), which are consistent with the Palermo Protocol (TRAFFICKING IN PERSONS REPORT, 2013, p. 41)

Atualmente essa publicação do Departamento de Estado norte-americano se apresenta como uma ferramenta e referência para acadêmicos e interessados pelo tema. O Trafficking in Person Report se mostra como consolidador de dados e sua periodicidade anual o torna interessante na medida em que possibilita a comparação do mesmo Estado ano a ano.

Outra maneira de se auferir o compliance com os Estados é o Global Slavery Index, ${ }^{14}$ que apresenta um índice desenvolvido no âmbito societal, pela ONG Walk Free Foundation. O índice fornece o ranking quantitativo de 162 países ao redor do mundo, de acordo com a prevalência estimada de escravidão, isto é, o percentual estimado de pessoas escravizadas na população nacional em um ponto no tempo. Além de oferecer uma estimativa do tamanho do problema da escravidão moderna, país por país.

Este outro indicador, sendo em sua natureza um ranking, é computado da seguinte maneira: o $1^{\circ}$ lugar é a pior posição enquanto que o $162^{\circ}$ lugar representa a melhor posição do ranking. Ao se analisar a metodologia de mensuração do Índice de Escravidão Global (tradução livre) este fornece um ranking, refletindo uma medida ponderada combinada de três variáveis: a prevalência estimada de escravidão moderna em cada país (que representam 95\% do total); a medida do nível de tráfico de seres humanos que entra e sai em cada país (responsável por 2,5\%); e a medida do nível de casamentos infantis e precoces em cada país (responsável por $2,5 \%)^{15}$

Ainda é possível mencionar outra ferramenta como indicador de compliance com a questão do tráfico de pessoas, o Human Trafficking Case Law Database, ${ }^{16}$ desenvolvida pelo

\footnotetext{
${ }_{15}^{14}$ Texto na íntegra disponível em: 〈http://www.globalslaveryindex.org/explore/>. Acesso em: 2 abr. 2014.

15 Para mais acerca da metodologia adotada: <http://www.globalslaveryindex.org/about/\#methodology>

${ }^{16}$ Texto na íntegra disponível em: <http://www.unodc.org/cld/index.jspx.> Acesso em: 2 abr. 2014.
} 
UNODC. Compreende uma base de dados de jurisprudência acerca de casos que tratem de tráfico de seres humanos, fornecendo acesso imediato e público a instâncias oficialmente documentadas deste crime.

O banco de dados contém detalhes sobre vítimas e perpetradores, nacionalidades, rotas de tráfico, veredictos e outras informações relacionadas aos casos julgados de todo o mundo. Assim, este banco de dados da ONU oferece não só estatísticas sobre o número de processos e condenações, mas também dados qualitativos de casos das pessoas traficadas como documentado pelos tribunais. A metodologia empregada para a criação e a alimentação do Human Trafficking Case Law Database é a coleta de casos junto às autoridades competentes de cada país (no Brasil, por exemplo, a autoridade competente é o Ministério Público Federal), sendo exigida para a inclusão do caso no banco de dados a condição de que todos os três elementos constitutivos na definição de tráfico de pessoas do Protocolo de Palermo estejam presentes, mesmo que o caso não tenha sido processado nos termos da legislação nacional específica do tráfico (os três elementos constitutivos do tráfico de pessoas são o ato, os meios e os fins de exploração). ${ }^{17}$

Quando se trata da revisão da literatura é imprescindível apontar que existem estudos de casos específicos de alguns países em que autores buscam fazer um balanço analítico de como determinado país tem se comportado em relação com os tratados internacionais na matéria de tráfico internacional de pessoas, fazendo com que essa literatura de estudo de caso também seja uma das maneiras da literatura de tráfico internacional de pessoas se conectar ao conceito de compliance.

Apenas a título de exemplificação, cita-se Michelle Gueraldi (2013), com seu artigo Human trafficking and challenges to States'compliance with International Human Rights Law: The case of Brazil. Neste artigo, a autora identifica alguns desafios enfrentados pelo Brasil na erradicação do tráfico humano, relacionando o problema à literatura sobre migrações e Direitos Humanos. Gueraldi argumenta que a Política Nacional de Enfrentamento ao Tráfico (decorrente da ratificação do Protocolo de Palermo pelo Estado brasileiro), implementada no Brasil a partir de 2008, não vai ao encontro dos pilares essenciais que o direito internacional dos Direitos Humanos prevê (prevenção do tráfico, a repressão dos perpetradores e a proteção

\footnotetext{
${ }^{17}$ Para mais informações sobre a metodologia adotada: 〈http://www.unodc.org/cld/en/about/faq.html>
} 
às vítimas $\left.{ }^{18}\right)$. A autora concebe seu artigo - ao contrário do que é comumente realizado quando tratado de tráfico humano - sob o guarda-chuva dos Direitos Humanos e não sob a ótica de crime penal (GUERALDI, 2013).

Outro exemplo que merece menção é o artigo Compliance with International Law on Trafficking by the Philippines: A Critical Analysis, sendo este desenvolvido por Mariesther Vedaña, também em 2013. Neste trabalho o autor apresenta como objetivo a análise de as Filipinas terem comply com as diretrizes assumidas diante do Protocolo de Palermo, bem como diante dos requisitos mínimos requeridos pelo Departamento de Estado norte-americano e seu Trafficking Victms Protection Act. ${ }^{19}$ Logo no início de seu artigo a autora afirma categoricamente que "Prior to the UN's Trafficking Protocol in 2000 almost all of the States did not have a particular law specifically defining and addressing trafficking in persons" (VEDANÃ, 2013, p. 1), propondo assim que seu trabalho seja um recorte na Lei Filipina $n^{\circ}$ 9208 acerca de tráfico de pessoas - criada após o Protocolo de Palermo - e em como este país tem se comportado em relação aos compromissos assumidos e as obrigações efetivamente levadas à cabo. Em seu artigo Vedaña também discute acerca do ranking filipino dentro do Trafficking in Person Report, demonstrando em suas conclusões que as Filipinas ainda possuem um longo caminho até a um efetivo enfrentamento a esse crime transnacional e a erradicação do tráfico internacional de pessoas.

Percebe-se, portanto, que há um avanço da literatura de tráfico internacional de seres humanos e compliance. Existem publicações acadêmicas, seja com recortes específicos como o de Gueraldo e o de Vedanã, seja tratando a questão de compliance de maneira mais generalizada, como o trabalho de King. Além disso, há indicadores que buscam mensurar o comportamento dos Estados tendo o Protocolo de Palermo como referencial. Assim, pode-se analisar que a literatura do objeto de análise não é limitada, possuindo uma gama diferenciada de literaturas. Contudo, a literatura não tem avançado com tanta fluidez e a rapidez que é necessária para que se tenha referenciais teóricos consolidados. Para que a literatura seja

\footnotetext{
${ }^{18}$ Como já abordado, esses pilares considerados pela autora, são os mesmos encontrados nas Diretrizes da ONU, pela sua agência UNDOC e do Trafficking in Person Report.

${ }_{19}$ Para mais informações acerca do TVPA, ver: CHUANG, J. The United States as a Global Sherif: Using Unilateral Sanctions to Combat Human Trafficking. Michigan Journal of International Law, v. 27, n. 2, p. 441494, 2006.
} 
consistente, é necessário que haja maior tempo de maturação e desenvolvimento das produções.

\section{CONSIDERAÇÕES FINAIS}

O trabalho buscou realizar um balanço abrangente da literatura sobre o tráfico internacional de pessoas, enfatizando a conexão desse tema com o debate sobre compliance e tratados internacionais. Constatou-se a preponderância de trabalhos qualitativos em contraposição a trabalhos quantitativos. Ainda que nos últimos anos, os pesquisadores que se dedicam ao tema tenham produzido um número crescente de artigos e publicações de natureza quantitativa, existem gargalos na produção de dados e na mensuração dos fenômenos que contribuem para limitar essa produção no campo dos estudos sobre esse tema.

Grande parte da literatura desenvolvida analisa a questão do tráfico humano à luz do Protocolo de Palermo, sendo que este se baseia em três distintos pilares para o enfrentamento bem-sucedido da atividade ilícita: a prevenção, a repressão, e a punição.

De acordo com o balanço da literatura levantada, conclui-se que as publicações desenvolvidas até então apresentam uma divisão em duas vertentes: a primeira avalia o poder de repressão e punição desempenhado pelo sistema criminal e reflete sobre as políticas públicas que devem ser priorizadas segundo a lógica própria desse sistema. A segunda vertente dialoga diretamente com a literatura sobre os Direitos Humanos, buscando apreciar as políticas públicas que lidam com as causas mais indiretas do problema, ou seja, baseada no pilar da prevenção. Assim com colocado anteriormente, o fato de haver maior ênfase da primeira vertente à repressão e punição e da segunda vertente à prevenção, não significa dizer que os sistemas de justiça criminal não atuem sob aspectos preventivos e que a perspectiva de Direitos Humanos não apoie determinadas ações de repressão e punição. A análise realizada neste artigo procura justamente reconhecer os componentes teóricos e metodológicos específicos de que cada uma das vertentes identificadas.

O debate entre essas vertentes ainda é incipiente, e o balanço que se faz aqui é de que esses dois campos principais venham a apresentar uma possível polarização, a exemplo do 
que ocorre em áreas próximas. Apesar de ser essencial considerar-se que as medidas de prevenção sejam baseadas no reconhecimento de que o tráfico humano é causado pela ausência e falha da proteção efetiva aos Direitos Humanos, fazendo com que o tráfico de pessoas seja causa e consequência de violações de Direitos Humanos, não se pode declinar da importância do sistema de justiça criminal no controle e na prevenção do tráfico de pessoas, o que nos coloca diante da necessidade de se estudar os processos específicos que afetam o funcionamento desse sistema, como é exemplo os esforços do UNODC.

É possível reconhecer a tendência de se considerar cada vez mais o conceito de compliance como um conceito útil para se estudar o problema das respostas ao tráfico internacional de pessoas. Assim, essas literaturas devem ser analisadas de maneira conjunta, buscando maior convergência entre ambas, sendo um interessante campo temático para futuras investigações. Conclui-se, então, que apesar do tráfico humano ser uma questão complexa, instrumentos internacionais legais já foram colocados em prática para ajudar a combatê-lo em escala global. 


\section{BIBLIOGRAFIA}

BRADFORD, W. International Legal Compliance: An Annoted Bibliografy. Universalising International Law, v. 34, p. 379-428, 2004.

CHAYES, A.; CHAYES, A. On Compliance. International Organization, v. 47, n. 2, p. 175-205, 1993.

CHUANG, J. The United States as Global Sheriff: Using Unilateral Sanctions to Combat Human Trafficking. Michigan Journal of International Law, v. 27, n. 2, p. 441-494, 2006.

CONVENÇÃO das Nações Unidas contra o Crime Organizado Transnacional. 15 nov. 2000. Disponível em: <http://www.planalto.gov.br/ccivil_03/_ato2004-2006/2004/decreto/d5015. htm>. Acesso em: 5 mar. 2014.

DOWNS, G. W.; ROCKE, D. M.; BARSOOM, P. N. Is the good news about compliance good news about cooperation? International Organization, v. 50, n. 3, p. 379-406, 1996.

EZEILO, J. N. Report of the Special Rapporteur on trafficking in persons, especially women and children. Annual Report - UN General Assembly, 64 session, 2009.

FARRIOR, S. The International Law of Human Trafficking in Women and Children for Prostitution: Making it Live Up to is Potential. Harvard Human Rights Journal, v. 10, p. 213-255, 1997.

HENDRIX, M. C. Enforcing the U.S. Trafficking Victims Protections Act in Emerging Markets: The Challenge of Affecting Change in India and China. Cornell International Law Journal, v. 43, p. 173-205, 2010.

HILLEBRECHT, C. Rethinking Compliance: The Challenges and Prospects of Measuring Compliance with International Human Rights Tribunals. Journal of Human Rights Practice, v. 1, n. 3, p. 362-379, 2009.

INTERNATIONAL ORGANIZATION FOR MIGRATION (IOM), IOM Global Human Trafficking database counter trafficking division. 2007. Disponível em: http://pt.scribd.com/doc/223701891/Iom-Ctm-Database. Acesso em: 20 set. 2014. 
KING, L. International Law and Human Trafficking. Human Rights \& Human Welfare, v. 1, p. 88-103, 2008.

LACZKO, F.; GRAMEGNA, M. Developing better indicators for human trackiffing. Brown Journal of World Affairs, v. X, n. 1, p. 179-194, 2003.

MICHELLE, G. Human trafficking and challenges to States'compliance with International Human Rights Law: The case of Brazil. Cultural Dynamics, v. 25, n. 2, p. 165-181, 2013.

MITCHELL, S.; HENSEL, P. International Institutions and Compliance with Agreements. American Journal of Political Science, v. 51, n. 4, p. 721-737, 2007.

NAÍM, M. Ilícito: o ataque da pirataria, da lavagem de dinheiro e do tráfico à economia global. Rio de Janeiro: Jorge Zahar Editores, 2006.

PARREÑAS, R.; HWANG, M.; LEE, H. What is Human Traffcking? A review essay. Signs, v. 37, n. 40, p. 1.015-1.029, 2012.

PIOVESAN, F. KAMIMURA, A. Tráfico de Pessoas sob a perspectiva de direitos humanos: prevenção, combate, proteção às vítimas e cooperação internacional. BRASÍLIA: Ministério da Justiça, v. 1, 2013.

PROTOCOLO Adicional à Convenção das Nações Unidas contra o Crime Organizado Transnacional Relativo à Prevenção, Repressão e Punição do Tráfico de Pessoas, em Especial Mulheres e Crianças. 15 nov. 2000. Disponível em: <https://treaties.un.org/doc/Publication/UNTS/Volume\%202237/v2237.pdf>. Acesso em: 5 mar. 2014.

RAUSTIALA, K.; SLAUGHTER, A. S. International Law, International Relations, and Compliance. In: SIMMONS, B.; CARLSNAES, W.; RISSE, Th. (Org.). Handbook of International Relations. Londres: Sage Publications, 2002.

SIMMONS, B. Compliance with International Agreements. Annual Review Political Science, 1: 75-93, 1998.

TODRES, J. Moving Upstream: The Merits of a Public Health law approach to human trafficking. North Carolina Law Review, v. 89, p. 447-506, 2011.

UNITED NATIONS. A Convenção da ONU para a Supressão sobre Tráfico de Pessoas e a Exploração da Prostituição de Outros. 2 dez. 1949. Disponível em: <https://treaties.un.org/doc/Publication/UNTS/Volume\%2096/v96.pdf>. Acesso em: 3 abr. 2014. 
UNITED NATIONS, United Nations Office on Drugs and Crime. (2010), The Globalization of Crime. Jun 2010. Disponível em: <https://www.unodc.org/unodc/en/data-andanalysis/tocta-2010.html>. Acesso em: 20 mar. 2014.

UNITED NATIONS, United Nations Office on Drugs and Crime. (2012), Global Report on Trafficking in Person. Dez. 2012. Disponível: <http://www.unodc.org/documents/data-andanalysis/glotip/Trafficking_in_Persons_2012_web.pdf>. Acesso em: 20 mar. 2014.

UNITED NATIONS, United Nations Office on Drugs and Crime. Human Trafficking Case Law Database. Disponível em: 〈http://www.unodc.org/cld/index.jspx> Acesso em: 1 mai. 2014.

UNITED STATES OF AMERICA, United States Department of State 2011. Trafficking in Persons $\quad$ Report. 19 jun 2013.2014 Disponível <http://www.state.gov/j/tip/rls/tiprpt/index.htm>. Acesso em: 15 abr. 2014.

VEDAÑA, M. Compliance with International Law on Trafficking by the Philippines: A Critical Analysis. Iamure International Journal of Social Sciences, v. 8, n. 1. 2013.

WALK FREE FOUNDATION. Global Slavery Index 2013. Disponível em: <http://www.globalslaveryindex.org/>. Acesso em: 2 maio 2014.

ZILBERSZTAJN, D.; SZTAJN, R. Economia e Direito - análise econômica do direito e das organizações. Rio de Janeiro: Campus, 2005. 
6 APÊNDICE A

\begin{tabular}{|c|c|c|c|c|}
\hline \multicolumn{5}{|c|}{ Quadro 1 - Quadro de Publicações Levantadas } \\
\hline AUTOR & TÍTULO & FORMATO & $\begin{array}{l}\text { ANO DE } \\
\text { PUBLICAÇÃO }\end{array}$ & PRIORIDADE \\
\hline William Bradford & $\begin{array}{l}\text { International Legal Compliance: } \\
\text { An Annoted Bibliografy }\end{array}$ & $\begin{array}{l}\text { Resenha } \\
\text { publicada }\end{array}$ & 2004 & Alta \\
\hline Beth A Simmons & $\begin{array}{l}\text { Compliance With Internacional } \\
\text { Agreements }\end{array}$ & Artigo & 1998 & Alta \\
\hline $\begin{array}{l}\text { Frank Laczko e Marco } \\
\text { Gramegna }\end{array}$ & $\begin{array}{l}\text { Developing better indicators for } \\
\text { Human Trackiffing }\end{array}$ & Artigo & 2003 & Alta \\
\hline Courtney Hillebrecht & $\begin{array}{l}\text { Rethinking Compliance: The Challenges and } \\
\text { Prospects of Measuring Compliance with } \\
\text { International Human Rights Tribunals }\end{array}$ & Artigo & 2009 & Alta \\
\hline Lindsey King & International Law and Human Trafficking & Artigo & 2008 & Alta \\
\hline $\begin{array}{l}\text { Kal Raustiala e } \\
\text { Anne Slaughter }\end{array}$ & $\begin{array}{l}\text { International Law, International Relations and } \\
\text { Compliance }\end{array}$ & Artigo & 2002 & Alta \\
\hline Jonathan Todres & $\begin{array}{l}\text { Moving upstream: The merits of a public health } \\
\text { law approach to human trafficking }\end{array}$ & Artigo & 2011 & Alta \\
\hline $\begin{array}{l}\text { Abram Chayes e } \\
\text { Antonia Handler } \\
\text { Chayes } \\
\end{array}$ & On Compliance & Artigo & 1993 & Alta \\
\hline Jonas Tallberg & $\begin{array}{l}\text { Paths to Compliance: Enforcement, } \\
\text { Management, and the European Union }\end{array}$ & Artigo & 2002 & Alta \\
\hline Stephanie Farrior & $\begin{array}{l}\text { The International Law of Human Trafficking in } \\
\text { Women and Children for Prostitution: } \\
\text { Making it Live Up to is Potential } \\
\end{array}$ & Artigo & 1997 & Alta \\
\hline Janie Chuang & $\begin{array}{l}\text { The United States as Global Sheriff: Using } \\
\text { Unilateral Sanctions to Combat Human } \\
\text { Trafficking. }\end{array}$ & Artigo & 2006 & Alta \\
\hline $\begin{array}{l}\text { Rhacel Parreñas, } \\
\text { Maria Hwang e } \\
\text { Heather Lee }\end{array}$ & What is Human Trafficking? A Review Essay & Artigo & 2012 & Alta \\
\hline $\begin{array}{l}\text { Felipe Bertoni e } \\
\text { Diogo Carvalho }\end{array}$ & Criminal Compliance e Lavagem de Dinheiro & Livro & 2013 & Média \\
\hline $\begin{array}{l}\text { Guilherme Cunha } \\
\text { Werner }\end{array}$ & $\begin{array}{l}\text { O Crime Organizado Transnacional e as Redes } \\
\text { Criminosas: Presença e Influência nas Relaçôes } \\
\text { Internacionais Contemporâneas }\end{array}$ & $\begin{array}{l}\text { Tese de } \\
\text { Doutorado }\end{array}$ & 2009 & Média \\
\hline $\begin{array}{l}\text { Sara Mitchell e } \\
\text { Paul Hensel }\end{array}$ & \begin{tabular}{|l} 
International Institutions and Compliance with \\
Agreements
\end{tabular} & Artigo & 2007 & Média \\
\hline Jonathan Todres & Law, Otherness and Human Trafficking & Artigo & 2009 & Média \\
\hline Marina Kaneti & $\begin{array}{l}\text { Project Trafficking: Global Unity in Addressing } \\
\text { a Universal Challenge }\end{array}$ & Artigo & 2011 & Média \\
\hline $\begin{array}{l}\text { Kenneth Abbot, } \\
\text { Robert Keohane, } \\
\text { Andrew Moracsik, } \\
\text { Anne Slaughter e } \\
\text { Duncan Snidal }\end{array}$ & The Concept of Legalization & Artigo & 2000 & Média \\
\hline
\end{tabular}




\begin{tabular}{|c|c|c|c|c|}
\hline $\begin{array}{l}\text { Abram Chayes e } \\
\text { Antonia Chayes }\end{array}$ & $\begin{array}{l}\text { The New Sovereignty: Compliance with } \\
\text { International Regulatory Agreements }\end{array}$ & $\begin{array}{l}\text { Resenha } \\
\text { publicada }\end{array}$ & 1997 & Média \\
\hline Lesley Wexler & $\begin{array}{l}\text { The Non-Legal Role of International Human } \\
\text { Rights Law in Addressing Immigration }\end{array}$ & Artigo & 2007 & Média \\
\hline Beth Simmons & $\begin{array}{l}\text { Explaining Variation in State Commitment to } \\
\text { And Compliance with International Human } \\
\text { Rights Treaties }\end{array}$ & Artigo & 2008 & Média \\
\hline Ethan Nadelmann & $\begin{array}{l}\text { Global Prohibition Regimes: The Evolution of } \\
\text { Norms in International Society }\end{array}$ & Artigo & 1990 & Média \\
\hline $\begin{array}{l}\text { Conny Rijken } \\
\text { e Dagmar Koster }\end{array}$ & $\begin{array}{l}\text { A Human Rights Based Approach to Trafficking } \\
\text { in Human Beings in Theory and Practice }\end{array}$ & Artigo & 2008 & Baixa \\
\hline Janie Chuang & $\begin{array}{l}\text { Beyond a Snapshot: Preventing Human } \\
\text { Trafficking in the Global Economy }\end{array}$ & Artigo & 2006 & Baixa \\
\hline Pritha Sem & $\begin{array}{l}\text { Combating Human Trafficking through Social } \\
\text { Policing }\end{array}$ & $\begin{array}{l}\text { Notícia } \\
\text { em periódico }\end{array}$ & 2006 & Baixa \\
\hline John H. Knox & Horizontal Rights Law & Artigo & 2008 & Baixa \\
\hline $\begin{array}{l}\text { Laura Langbein e } \\
\text { Cornelius Kerwin }\end{array}$ & $\begin{array}{l}\text { Implementation, Negotiation and Compliance in } \\
\text { Environmental and Safety Regulation }\end{array}$ & Artigo & 1985 & Baixa \\
\hline $\begin{array}{l}\text { Kathleen Kim e } \\
\text { Grace Chang }\end{array}$ & $\begin{array}{l}\text { Reconceptualizing Approaches to Human } \\
\text { Trafficking:New Directions and Perspectives } \\
\text { From the Field(s) }\end{array}$ & Artigo & 2007 & Baixa \\
\hline Jonathan Todres & $\begin{array}{l}\text { The Private Sector's Pivotal Role in Combating } \\
\text { Human Trafficking }\end{array}$ & Artigo & 2012 & Baixa \\
\hline Anne Gallagher & $\begin{array}{l}\text { Using International Human Rights Law to Better } \\
\text { Protect Victims of Trafficking: The Prohibitions } \\
\text { on Slavery, Servitude, Forced Labor and Debt } \\
\text { Bondage }\end{array}$ & Artigo & 2008 & Baixa \\
\hline $\begin{array}{l}\text { Elzbieta Gozdziak e } \\
\text { Micah Bump }\end{array}$ & Data and Research in Human Trafficking & Livro & 2008 & Baixa \\
\hline $\begin{array}{l}\text { Robert Howse e } \\
\text { Ruti Teitel }\end{array}$ & $\begin{array}{l}\text { Beyond Compliance: Rethinking Why } \\
\text { International Law Really Matters }\end{array}$ & Artigo & 2010 & Baixa \\
\hline
\end{tabular}




\title{
ARTIGO II
}

Programa de Pós-Graduação em Relações Internacionais

Universidade de São Paulo

Instituto de Relações Internacionais

\section{TRÁFICO INTERNACIONAL DE PESSOAS NAS AMÉRICAS: UM BALANÇO COMPARATIVO DE POLÍTICAS PÚBLICAS}

\author{
Pesquisador: Gabriel Dantas Araujo \\ Orientador: Leandro Piquet Carneiro
}




\section{RESUMO}

Este trabalho tem por objetivo realizar uma pesquisa empírica acerca do desenvolvimento do tema de tráfico internacional de pessoas e como essa atividade ilegal tem implicações nas políticas públicas de países das Américas. O tráfico humano foi abordado sob a óptica das relações internacionais com foco no papel da Convenção de Palermo e seu Protocolo Adicional. Buscou-se analisar como este tratado internacional influenciou a adoção de políticas públicas e na política penal de treze países das Américas, sendo uma das metas desta pesquisa descrever e avaliar o processo de compliance que os Estados desenvolveram em face das normas globais vigentes.

A hipótese do artigo é a de que com a Convenção de Palermo, como marco regulatório, a ONU harmonizou as normas jurídicas domésticas das nações da amostra. Foram realizadas análises comparativas entre as políticas públicas adotadas nos países da região das Américas, buscando demonstrar correlações entre a influência prévia do crime organizado na região e o comportamento dos países no desenvolvimento das políticas públicas.

Palavras-Chave: Tráfico Internacional de Pessoas; Américas; Políticas Públicas; Compliance; Protocolo de Palermo. 


\title{
International Human Trafficking in the Americas: A Comparative Balance of Public Policies
}

\begin{abstract}
This work aims to conduct empirical research on the development of international human trafficking theme and how this illegal activity has implications for public policies in the Americas. Human trafficking was approached from the perspective of international relations with a focus on the role of the Palermo Convention and its Additionals Protocols. It sought to analyze how this international treaty has influenced the adoption of public policies and penal policy of 13 selected countries in the Americas, been one of the research's aims to describe and evaluate the compliance process that national states have developed to face the current global standards.
\end{abstract}

The hypothesis of the article is that with the regulatory framework that was the Palermo Convention, the United Nations harmonized the domestic legal provisions of the selected nations. Comparative analyzes were performed between public policies adopted in the countries of the Americas region, seeking to demonstrate correlations between the prior influence of organized crime in the area and the behavior of countries in the development of public policies.

Key Words: International Human Trafficking; Americas; Public Policy; Compliance; Palermo Protocol. 


\section{Lista de Tabelas}

Tabela 1 - Agrupamento de treze países das Américas de Acordo com o Índice Composto de

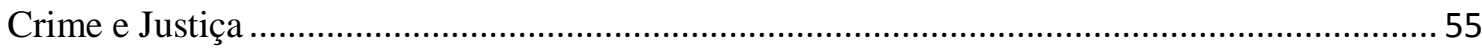

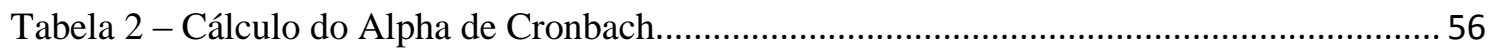

Tabela 3 - Número de casos em cada cluster e média da escala ICCJ segundo o cluster ............ 57

Tabela 4 - Políticas Públicas nas Américas sobre Tráfico de Pessoas ......................................... 59

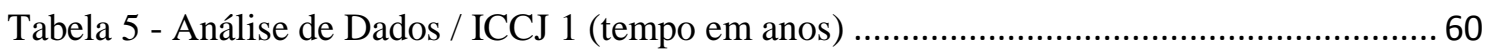

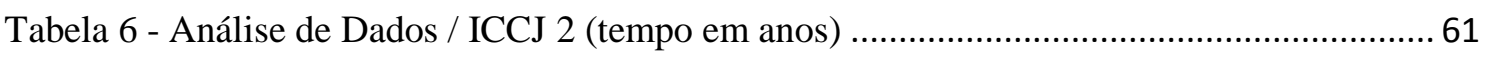

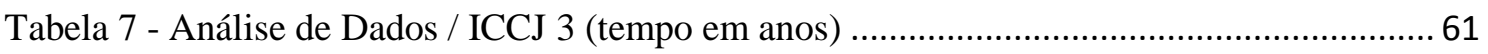

Tabela 8 - Indicadores de Compliance ao Enfrentamento ao Tráfico Humano nas Américas.... 64

Tabela 9 - Análise dos indicadores de compliance .............................................................65

Tabela 10 - Mobilização Institucional para o Enfrentamento ao Tráfico de Pessoas, 2000-2014 


\section{Lista de Figuras}

Figura 1 - Gráfico de Dispersão dos países de acordo com o ICCJ e Penas Máximas 


\section{INTRODUÇÃO}

O presente estudo analisa o tráfico de pessoas sob a óptica das relações internacionais baseado principalmente no marco legal dedicado ao seu enfrentamento, a Convenção de Palermo e seu Protocolo Adicional. Abordar-se-á como esse tratado influenciou na mudança das políticas públicas de segurança no Brasil e em outros doze países selecionados da região das Américas. Será realizada uma análise empírica relacionada a essas mudanças ocorridas nas políticas públicas voltadas para o enfrentamento ao tráfico internacional de seres humanos e o processo de compliance com as normativas internacionais observado nos países selecionados. Assim, serão levantados os principais esforços nestes países a partir de uma breve descrição de cada um deles a fim de proporcionar uma análise comparada entre os países.

O Tráfico Internacional de Pessoas é um crime que se configura como uma das principais ameaças à segurança internacional no início do século XXI e na região das Américas essa realidade não é diferente. Contudo, deve-se levar em consideração o fato de que nem sempre questões relacionadas à segurança societal foram consideradas ameaças à segurança internacional, tendo em vista que durante grande parte do século XX houve a prevalência da abordagem neorrealista, com particular ênfase nos conflitos estatais e militares. Com o término da Guerra Fria (1945-1991), houve um alargamento deste entendimento, incluindo ameaças políticas, assuntos relacionados a direitos humanos, migração e questões econômicas e ambientais.

Nos estudos de segurança no âmbito das relações internacionais, geralmente, havia forte predominância da perspectiva de neorrealistas. No entanto, muitos autores preconizam a expansão do conceito de segurança internacional, bem como sua adequação à realidade dos novos desafios e novas ameaças presente à ordem global. Dessa forma, as categorias tradicionais precisam ser reavaliadas com base na percepção de novos fenômenos. Crises econômicas e alimentares, questões ambientais, de direitos humanos, de migrações e tráfico de pessoas são hoje consideradas no debate de novas formas de pensar a segurança humana.

É primordial buscar contemplar os eixos da expansão e aprofundamento da agenda dos estudos de segurança, por meio do alargamento do conceito de ameaça e da inclusão de novos atores necessitados de proteção. Simultaneamente, é necessário admitir termos que 
possibilitem a superação do dilema da segurança e a possibilidade de cooperação multilateral em questões de segurança internacional. Nesse contexto, portanto, há como um dos pressupostos uma nova ameaça à segurança humana, sendo este o crime organizado internacional, em que a Convenção das Nações Unidas Contra o Crime Transnacional - a chamada Convenção de Palermo - surge como uma possibilidade de cooperação multilateral.

Para um verdadeiro entendimento dos estudos de segurança, convém expandir seu conceito. Em primeiro lugar é preciso distinguir entre dois tipos de segurança: a segurança estatal - associada à soberania e aos tradicionais perigos militares; e a segurança societal vinculada à identidade coletiva (KRAUSE; WILLIAMS, 1996). Nossa visão vai ao encontro do segundo ponto, no qual a segurança societal foi englobada como de suma importância, sendo tanto o crime organizado internacional quanto o tráfico internacional de pessoas ameaças a esta.

Colocar o caso do enfrentamento ao crime organizado transnacional como caso exemplar de uma nova ameaça, como aqui se defende, permite alargar a agenda de segurança, pois ao fazê-lo ocorre a implicação de reajustes (inclusive públicos e militares) nas instituições, nas diretrizes de defesa dos Estados e nas políticas públicas praticadas pelos diferentes países.

O artigo está organizado em sete seções: primeiro, esta breve introdução; na segunda seção discorre-se sobre a variável dependente do estudo e as hipóteses testadas; em seguida, analisa-se a legislação internacional relacionado a este assunto; na quarta seção são apresentados a seleção amostral e os motivos dessa escolha; na quinta seção demonstrar-se-ão os dados levantados acerca das políticas públicas de segurança no que se refere ao crime do tráfico de seres humanos e as análises desses dados; na sequência são arrolados outros dados concernentes aos indicadores de compliance, bem como algumas análises próprias; e, por fim, pretende-se mencionar as considerações finais. 


\section{HIPÓTESES DO ESTUDO}

O presente artigo baseia-se na hipótese inicial de que a Convenção de Palermo harmonizou as normas jurídicas domésticas de diversas nações da região das Américas, dentre elas a brasileira. A partir da variável independente - criação da Convenção de Palermo - e da questão conceitual do compliance, foram estabelecidos alguns componentes operacionais avaliação de que ações foram tomadas, qual a forma destas ações e o grau de intensidade para a averiguação da variável dependente do estudo (harmonização ou não harmonização das leis nacionais com a convenção internacional).

A criação da Convenção de Palermo é a principal variável independente do estudo, tendo em vista ser a base de comparação primária sobre a qual serão desenvolvidas análises dos países da amostra no que se refere a seus posicionamentos em relação ao Protocolo Relativo à Prevenção, Repressão e Punição do Tráfico de Pessoas, em Especial Mulheres e Crianças desta mesma Convenção.

Considerando como variável dependente aquela que está sujeita aos procedimentos de investigação, e as quais possuem relação de causa e efeito com as hipóteses do estudo (SOUSA, 2005), analisar-se-á para cada país os seguintes componentes: I) a ratificação ou não do Protocolo de Palermo relativo ao Tráfico de Pessoas - sendo este o componente primário da variável dependente que mais correlação apresenta com a variável independente e a qual norteará todas as outras dimensões de análise; II) a data de ratificação ou aceite ao Protocolo - estando atrelada a primeira variável, será base de comparação entre os países da amostra, buscando entender o tempo de resposta de cada país ao compliance global no enfrentamento ao tráfico; III) as normas produzidas - variável que demonstrará se de fato houve mudanças condizentes com as normas internacionais e qual o grau de envolvimento que o país buscou ter com esta; IV) a data de criação destas normas locais - outra dimensão de análise com idêntico intuito da segunda variável, porém buscando entender o tempo de resposta para a efetiva mudança na política pública nacional; V) a pena máxima estabelecida para o crime de tráfico humano - as penas estabelecidas são variáveis que buscam refletir por 
meio da intensidade da punição a importância que o país estabelece como ameaça à segurança humana.

A hipótese proposta é a de que com a Convenção de Palermo, como marco regulatório internacional, a ONU conseguiu harmonizar as normas jurídicas domésticas de diversas nações, inclusive, a brasileira e de países vizinhos na América. Aventa-se a hipótese de que os países da amostra apresentaram modificações relevantes em suas políticas de segurança pública internacional depois do lançamento do Protocolo de Palermo para o tráfico de seres humanos. Isto é, esses países buscaram criar ou, pelo menos, aprimorar suas legislações internas para uma melhor adequação às novas regras globais neste tema de segurança pública. Dessa forma, testar-se-á a hipótese de compliance com as normas propostas pela ONU, avaliando-se quando as ações foram realizadas, de que forma o compliance foi buscado, e qual o grau de intensidade os países da região das Américas dão a este tema de política pública internacional.

\section{A CONVENÇÃO DE PALERMO E O TRÁFICO INTERNACIONAL DE PESSOAS}

Apesar de o crime organizado ser uma realidade há muitas décadas, considera-se como um dos marcos importantes nesta questão o final da Guerra Fria, representado pela queda do Muro de Berlim (1989). Encerrava-se uma etapa cujos problemas ainda não haviam sido solucionados. O mundo não se considerava globalmente seguro desde 1914, e não seria com a queda do muro que a estabilidade seria recomposta. Permanecia uma desordem, sem instrumentos próprios para extingui-la; uma desordem que gradativamente contribuía para o surgimento de um novo meio de se fazer guerra sem declará-la: o crime organizado transnacional.

Ao contrário do que se esperava com o fim da Guerra Fria, a ascensão do crime organizado no plano internacional foi facilitada. O declínio do número de conflitos mundiais e o aumento dos regionais exigiu grande demanda de armas e mão-de-obra. Os recursos materiais e humanos que alimentam esses conflitos regionais estavam muitas vezes ligados às atividades criminosas transnacionais por meio do comércio ilícito de drogas, armas, pessoas e joias. 
A partir dos anos 90 o crime global se expandiu auferindo além de lucros econômicos, uma força política sem precedentes. Força esta que influencia vigorosamente a dinâmica local onde estão baseadas as células criminosas e também exerce pressão direta ou indireta sobre os sistemas nacionais de segurança pública de diversos países (NAÍM, 2006). Desse modo, podese perceber que a globalização trouxe consigo características paradoxais. Ao mesmo tempo em que aumentou exponencialmente a mobilidade internacional e o fluxo de comércio, diminuiu virtualmente distâncias e aproximou governos e pessoas, criou um amplo espaço para o comércio ilícito. Essa mudança no sistema internacional foi rápida, sem possibilitar que as burocracias formais fossem superadas ou mesmo adaptadas, surgindo brechas que, por extensão, possibilitaram ao crime internacional se desenvolver e expandir.

Dentro desse sistema anárquico, indissociável do sistema internacional, as organizações criminosas adaptaram seu modus operandi e é neste contexto que, desde então, o crime organizado tem evoluído. Estimativas do Fundo Monetário Internacional do ano de 2009 sugerem que as atividades ilícitas rendem em torno de 3,6\% do Produto Interno Bruto global, alcançando cerca de US\$2,1 trilhões (UNODC, 2011, p. 7). Ainda mais crítico se torna o cenário ao se atentar que o dinheiro das atividades ilícitas ajuda no florescimento e crescimento de outras atividades criminosas, com consequências socioeconômicas negativas para a sociedade como um todo. Consequências estas que podem ser mais facilmente indicadas como problemas de saúde (quando se analisa, por exemplo, questões relacionadas ao abuso de drogas), aumento da violência e expansão da corrupção ou algumas consequências indiretas, mas que a afetam o desenvolvimento socioeconômico, como perda de produtividade e redução da economia como um todo. ${ }^{20}$

Ao se observar, atentamente, as consequências específicas do tráfico internacional de pessoas evidencia-se a exploração sexual - que representa a maior parte das pessoas traficadas - constitui, sobretudo, um problema para as pessoas em questão. A violência é usada principalmente contra as vítimas desse tipo de exploração, para torná-las submissas. A exploração sexual também pode acarretar problemas de saúde, pois as vítimas são forçadas a

\footnotetext{
${ }^{20}$ Estudos do UNODC realizados nos Estados Unidos apontam que um grande custo econômico do abuso de drogas é a perda da produtividade dos trabalhadores, que se encontram imersos no vício. Além de outros estudos que indicam que a cada US\$ 1 bilhão de dinheiro do crime organizado lavado é reduzido o crescimento econômico global em cerca de 0,04-0,06 pontos percentuais em dezessete países da OCDE. Para informações mais detalhadas ver: Estimating illicit financial flows resulting from drug trafficking and other transnational organized crimes, 2011. UNITED NATIONS OFFICE ON DRUGS AND CRIME, VIENNA.
} 
se envolver em práticas sexuais desprotegidas, aumentando, assim, os riscos de serem infectadas com o HIV e outras doenças sexualmente transmissíveis, podendo estimular outros trabalhadores do sexo a seguir este exemplo, a fim de permanecer neste ramo de negócio (UNODC, 2011).

\begin{abstract}
An analysis of criminal cases in the Netherlands (1999) suggested that criminals used, on average, $7 \%$ of their total criminal income for consumption and lifestyle, $57 \%$ for "conventional investment" (property, bank accounts, fixed interest assets and securities), 23\% for "irregular business" activities (legal or illegal) and 9\% for hoarding money, mainly for subsequent reinvestment into illegal activities. (UNODC, 2011, p. 99).
\end{abstract}

Atividades ilícitas tendem a formar um tipo particular de rede. Embora seja possível encontrar exemplos de redes transnacionais de organizações criminosas, por exemplo, a rede que conecta os carteis colombianos aos carteis mexicanos e aos grupos que distribuem a cocaína nos Estados Unidos. O formato típico de atuação é o de redes locais (microrredes) que estabelecem vínculos circunstanciais com outras organizações criminosas e com empresas legais (por exemplo, bancos e operadores financeiros diversos). Esses vínculos são descritos por Albanese e Reichel (2014) como um conjunto de "criminal exploitable ties" que podem ser estabelecidos e desfeitos rapidamente pela organização criminosa permitindo uma rápida resposta operacional diante da ação dos governos.

Por ser um sistema dinâmico, formada por redes de organizações criminosas que operam localmente e que se conectam a diferentes parceiros transnacionais em suas atividades ilícitas, as tentativas de regulação no nível mundial têm sido ainda insuficientes. Apesar da Convenção de Palermo ser um marco legal na luta contra o tráfico internacional de pessoas, e mais genericamente o crime organizado, é necessário relevar que essa luta contra o crime organizado transnacional não surgiu com esta. Trata-se, portanto, de um embate muito mais antigo que foi se desenvolvendo ao longo do século XX para culminar nesse importante marco, a mencionada Convenção. Nesse processo de mudança institucional, especificamente sobre o crime de tráfico de pessoas, o primeiro esforço em âmbito global surgiu com a antiga Liga das Nações, ainda no ano de 1926, ocupando-se exclusivamente com o tráfico de escravos (Convention to Suppress the Slave Trade and Slavery). Já sob os auspícios da ONU, no ano de 1956, foi assinada a Convenção Suplementar Sobre Abolição da Escravatura, do 
Tráfico de Escravos e das Instituições e Práticas Análogas à Escravatura - conhecida como Convenção de Genebra de 1956 -, incorporando parte dos tratados existentes e ampliando ainda mais a antiga visão de escravidão vigente até então, tendo sua efetiva entrada em vigor no ano de $1966 .^{21}$

A Convenção de Genebra representa, sem dúvida, um relevante mecanismo, visto que já pressupunha que seus Estados membros modificassem suas legislações internas para definir e criminalizar o tráfico de pessoas, bem como qualquer forma de escravidão. Ainda durante o século XX ocorreram diversas convenções, conselhos e conferências nos âmbitos de fóruns multilaterais que ajudaram a desenvolver programas, declarações, conceitos e definições na luta contra o tráfico de seres humanos. Todas essas discussões vão culminar, no final do século, na elaboração de um instrumento para tratar de todos os aspectos relativos ao tráfico de pessoas. Esse instrumento é o Protocolo das Nações Unidas para Prevenir, Suprimir e Punir o Tráfico de Pessoas, especialmente Mulheres e Crianças, que teve sua assinatura no ano de 2000 com entrada em vigor em 2003.

Como se pode perceber, apesar do Protocolo de Palermo não ter iniciado as ações e o esforço de regulação do tráfico de pessoas, certamente é um marco internacional decisivo no tema, por ser o mais completo, e também o que melhor oferece diretrizes para os Estados membros elaborarem legislações internas. Contudo, é possível apontar alguns pontos falhos no Protocolo ao observar que não especifica nenhum mecanismo de enforcement - capacidade de obrigar as partes a seguir o acordo estabelecido. Não há, por exemplo, nenhum sistema de monitoramento do cumprimento do Protocolo estabelecido pela Convenção de Palermo.

Esse processo de mudança institucional foi se desenvolvendo ao longo de décadas em que a Convenção de Palermo - e seu Protocolo - é fruto de uma gradativa construção institucional com o objetivo de criação de um sistema internacional de controle e regulação de várias atividades ilícitas. A premissa do economista Douglass North (1991) de que, no decorrer da história, as instituições são utilizadas pela sociedade com a finalidade de criar

\footnotetext{
21 Para mais informações acerca desta Convenção de Genebra, acessar: <http://www.direitoshumanos.usp.br/index.php/Emprego-Prote\%C3\%A7\%C3\%A3o-contra-todo-tipo-deescravid\%C3\%A3o-trabalhos-for\%C3\%A7ados-e-pr\%C3\%A1ticas-an\%C3\%A1logas/convencao-suplementarsobre-abolicao-da-escravatura-do-trafico-de-escravos-e-das-instituicoes-e-praticas-analogas-a-escravatura1956.html.>
} 
ordem e reduzir as incertezas, é válida, sendo o histórico e a própria Convenção de Palermo um exemplo disso.

A Convenção de Palermo ocorreu em 2000 na Itália, na data em questão, o Brasil e mais outros 123 países assinaram a Convenção das Nações Unidas Contra o Crime Transnacional. Hoje esse número é ainda maior, sendo 147 a totalidade de Estados nacionais que são signatários da referida convenção. ${ }^{22}$ A Convenção de Palermo foi estabelecida:

Deeply concerned by the negative economic and social implications related to organized criminal activities, and convinced of the urgent need to strengthen cooperation to prevent and combat such activities more effectively at the national, regional and international levels (ONU, 2004, 2).

Alguns dos tópicos abordados na Convenção foram: proteção da soberania; criminalização do financiamento do crime; medidas para combate da lavagem de dinheiro; responsabilidade coletiva; corrupção; jurisdição; extradição; assistência mútua legal; investigações e técnicas; assistência e proteção às vítimas; medidas para reforçar a cooperação; coleta, intercâmbio e análise de informações sobre a natureza do crime organizado; implementação da Convenção por meio do desenvolvimento econômico e da assistência técnica; dentre outras medidas.

Além do protocolo específico ao tráfico humano, há outros dois protocolos que abordam outras atividades ilícitas transnacionais; o Protocolo Relativo ao Combate ao Tráfico de Migrantes por Via Terrestre, Marítima e Aérea; e o Protocolo Contra a Fabricação e o Tráfico Ilícito de Armas de Fogo, suas peças e componentes e munições. Cabe ressaltar que os países devem ratificar a Convenção antes de aderir a qualquer um dos protocolos. ${ }^{23}$ Especificamente em relação ao protocolo que trata acerca do tráfico de pessoas, hoje 117 Estados são signatários, ${ }^{24}$ dentre os quais, diversos encontram-se na região das Américas. ${ }^{25}$

\footnotetext{
${ }^{22}$ Texto na íntegra disponível em: <https://treaties.un.org/Pages/ViewDetails.aspx?src=TREATY\&mtdsg _no=XVIII-12-a\&chapter=18\&lang=en>. Acesso em: 28 maio 2014.

${ }_{23}$ Texto na íntegra disponível em: <http://www.planalto.gov.br/ccivil_03/_ato20042006/2004/decreto/d5015.htm>. Acesso em: 16 mar. 2015.

${ }^{24}$ Para mais detalhes sobre os países que realizaram a assinatura e aqueles que ratificaram o mesmo, ver: $<$ https://treaties.un.org/Pages/ViewDetails.aspx?src=TREATY\&mtdsg_no=XVIII-12-a\&chapter=18\&lang=en>. Acesso em: 28 maio 2014.

${ }^{25}$ Para mais informações sobre outros mecanismos de cooperação regional e subregional para enfrentamento ao tráfico de pessoas, inclusive mecanismos de monitoramento, prevenção, combate, proteção e reparação, ver: Report submitted by the Special Rapporteur on trafficking in persons, especially women and children, Joy Ngozi
} 
Essa região é o foco do presente trabalho e na próxima seção, serão apresentados detalhes da amostra de países utilizada.

\section{SELEÇÃO DA AMOSTRA}

Foram selecionados intencionalmente treze países da região das Américas para a análise e teste da hipótese sobre os processos de compliance com a Convenção de Palermo. O desenho da amostra combina duas estratégias de comparação a de "sistemas semelhantes" (most similar systems) e de "sistemas diferentes" (most different systems) (PRZEWORSKI; TEUNE, 1982). Doze dos casos selecionados compartilham vários aspectos de sua história colonial e apresentam desenvolvimento institucional semelhante nos séculos XIX e XX, além da proximidade geográfica e da tradição jurídica comum. O caso desviante na amostra, Belize, tem uma série de diferenças importantes: o país teve uma independência tardia no século XX, e não no século XIX como os demais, tem um sistema legal de tipo common law e integra a Commonwealth, o que tem efeito sobre o processo de adoção de legislação dos países membros dessa comunidade em várias áreas.

Espanha e Portugal trouxeram para as Américas o direito civil romano de caráter doutrinário e legislativo, enquanto nas colônias Britânicas, como Belize, a base do sistema legal reside no direito consuetudinário, de caráter jurisprudencial e costumeiro (MERRYMAN; PERDOMO, 2007). O fato dos países considerados, com exceção de Belize, apresentarem sistemas jurídicos semelhantes permite "manter constante" um conjunto de características sistêmicas que podem afetar o fenômeno de interesse. Na medida em que interessa investigar os fatores que afetam o processo de compliance com as normativas da Convenção de Palermo, parece útil manter a comparação circunscrita a países que têm o mesmo tipo de sistema legal. Dessa forma é possível manter constante, no processo de comparação, uma característica que pode afetar diretamente o comportamento da variável dependente (o compliance das Partes com a norma internacional).

Belize foi incorporada na amostra com dois objetivos principais. Em primeiro lugar, por apresentar um sistema legal claramente distinto constitui-se como um caso desviante que

Ezeilo, A/HRC/14/32, 2010. Disponível em: 〈http://www.ohchr.org/en/Issues/Trafficking/Pages/annual.aspx>. Acesso em: 26 set. 2014. 
favorece a falsificação da hipótese principal do estudo. Em segundo lugar, o caso permite explorar hipóteses alternativas sobre o processo de compliance valendo-se de um processo de abdução lógica, ou seja, a partir da observação do comportamento do caso podemos oferecer hipóteses alternativas para o fenômeno (HEIJDEN, 2013).

No processo de comparação leva-se em conta ainda a variação no contexto criminal dos países. Fatores como o nível de violência letal, a presença de ameaças terroristas concretas no cenário doméstico, o histórico de violação dos Direitos Humanos, a corrupção no setor público, entre outros correlatos, podem afetar diretamente a capacidade de resposta dos países com relação ao tráfico de pessoas. ${ }^{26}$ Assim, os casos foram agrupados segundo o nível de incidência de problemas criminais e de funcionamento da justiça com base no indicador que foi criado para esse propósito, denominado Índice Composto de Crime e Justiça (ICCJ) e construído a partir de oito variáveis primárias apresentadas na Tabela 1. O ICCJ busca medir a presença do crime organizado e a força do sistema de justiça criminal nos países da amostra. A estratificação da amostra segundo esse índice mostrou-se necessária, uma vez que o tráfico de pessoas pode ser considerado diretamente uma forma de crime organizado transnacional e, portanto, a estratificação ao utilizar estas dimensões garante maior nível de controle na comparação. A análise multivariada de componentes principais permitiu estratificar a amostra em três clusters.

Foram levantadas informações sobre oito dimensões básicas do problema: 1) taxa de homicídios por 100 mil habitantes segundo a UNODC (2013); 2) Índice Global de Terrorismo, segundo o Institute for Economics and Peace (2011). Este índice mede o impacto do terrorismo no país por meio de uma média dos últimos cinco anos, pontuando de 1 (extremo impacto) para 116 (nenhum impacto). Evidências apontam que o terrorismo e crime organizado partilham recursos (FILHO; VAZ, 1997); 3) Conflito Interno segundo o Economist Intelligence Unit (2014), sendo esta uma avaliação qualitativa da intensidade dos conflitos no interior do país, classificada entre 1 a 5 (muito baixo a muito alto). O conflito interno é apenas outra dimensão observável do mesmo fenômeno que ocorre com a relação entre terrorismo e crime transnacional; 4) Índice de Risco de Direitos Humanos, segundo a Maplecroft - Global Risk Analytics (2014), que analisa a frequência, gravidade e a

\footnotetext{
${ }^{26}$ Para mais informações acerca da relação entre presença do crime organizado e sistema de justiça criminal ver: BAYLEY, D. Padrões de Policiamento. SÃO PAULO: EDUSP, 2001.
} 
cumplicidade de risco em diferentes categorias de Direitos Humanos (D.H.) em diversos países, pontuando de 1 a 4 (baixo à extremo). A associação se dá, pois o esforço de repressão ao crime organizado faz com que muitas vezes ocorram violações de D.H., como também os altos níveis de violação aos D.H. indicam fragilidade do sistema de justiça criminal, ou seja, os Direitos Humanos são violados porque há o esforço de controle, ou indicam fragilidade institucional (PIOVESAN; KAMIMURA, 2013); 5) Índice de Percepção da Corrupção, de acordo com a Transparency International (2013), sendo que o índice reflete a pontuação de países em uma escala de 0 (muito corrupto) a 100 (muito limpo). Evidências de grande parte da literatura convergem para os mesmos resultados de que a maior presença do crime organizado apresenta um maior índice de corrupção (ONU, 2011); 6) Liberdades Civis, segundo o Freedom House (2014), refletindo uma conjunção de variáveis, tais como: as liberdades de expressão e de crença, de associação e direitos organizacionais, o Estado de direito e a autonomia pessoal, sem interferência do Estado, no qual a pontuação 1 indica o melhor grau de liberdade e a pontuação 7 o pior grau. As liberdades civís nada mais são do que outra dimensão observável do problema dos D.Hs; 7) Percepção do Crime Organizado, de acordo com o World Economic Forum (2014), no qual analisa em que medida o crime organizado impõe custos ao setor privado, variando de 1 (em grande medida) para 7 (nenhum custo). A percepção de crime organizado é uma dimensão ligada ao objeto de análise de estudo; 8) Estado de Direito, segundo o World Bank (2012), no qual essa dimensão capta a percepção do grau em que os agentes têm confiança e respeitam as regras da sociedade, variando de $-2,5$ a 2,5 (pouca confiança a muita confiança). Essa variável também é considerada outra dimensão observável do fenômeno dos D.H. e das liberdades civis. 
Tabela 1 - Agrupamento de treze países das Américas de Acordo com o Índice Composto de Crime e Justica

\begin{tabular}{|c|c|c|c|c|c|c|c|c|c|}
\hline Fonte & $\begin{array}{l}\text { Homicide } \\
\text { Statistics }\end{array}$ & $\begin{array}{l}\text { Institute for } \\
\text { Economics } \\
\text { and Peace }\end{array}$ & $\begin{array}{l}\text { Economist } \\
\text { Intelligence } \\
\text { Unit }\end{array}$ & $\begin{array}{l}\text { Maplecroft - } \\
\text { Global Risk } \\
\text { Analytics }\end{array}$ & $\begin{array}{l}\text { Transparency } \\
\text { International }\end{array}$ & $\begin{array}{l}\text { Freedom } \\
\text { House }\end{array}$ & $\begin{array}{l}\text { World } \\
\text { Economic } \\
\text { Forum }\end{array}$ & $\begin{array}{l}\text { World } \\
\text { Bank }\end{array}$ & Elaboração Própria \\
\hline Ano & 2009 & 2011 & 2014 & 2014 & 2013 & 2014 & 2014 & 2012 & \\
\hline Dimensão & $\begin{array}{l}\text { Taxa de } \\
\text { Homicídios } \\
\text { (a) }\end{array}$ & $\begin{array}{l}\text { Índice Global de } \\
\text { Terrorismo (b) }\end{array}$ & $\begin{array}{l}\text { Conflito } \\
\text { Interno } \\
\text { Organizado (c) }\end{array}$ & $\begin{array}{l}\text { Índice de } \\
\text { Risco de } \\
\text { Direitos Humanos (d) }\end{array}$ & $\begin{array}{l}\text { Índice da } \\
\text { Percepção de } \\
\text { Corrupção (e) }\end{array}$ & $\begin{array}{l}\text { Liberdades } \\
\text { Civis (f) }\end{array}$ & $\begin{array}{l}\text { Percepção do } \\
\text { Crime Organizado } \\
(\mathrm{g})\end{array}$ & $\begin{array}{l}\text { Estado de } \\
\text { Direito (h) }\end{array}$ & $\frac{\text { Índice Composto }}{\text { de Crime e Justica }}$ \\
\hline Argentina & 3,4 & 67,0 & 2,0 & 2,0 & 106,0 & 2,0 & 4,4 & $-0,7$ & 1,0 \\
\hline Chile & 3,7 & 50,0 & 1,0 & 2,0 & 22,0 & 1,0 & 5,4 & 1,4 & 1,0 \\
\hline Costa Rica & 11,4 & 116,0 & 1,0 & 2,0 & 49,0 & 1,0 & 5,3 & 0,5 & 1,0 \\
\hline Uruguai & 6,8 & 116,0 & 1,0 & 2,0 & 19,0 & 1,0 & 6,0 & 0,5 & 1,0 \\
\hline Belize * & 31,8 & 91,0 & 3,0 & 2,0 & 113,0 & 2,0 & 2,6 & $-0,4$ & 2,0 \\
\hline Brasil & 21,7 & 116,0 & 1,0 & 3,0 & 72,0 & 2,0 & 4,0 & $-0,1$ & 2,0 \\
\hline El Salvador & 70,6 & 116,0 & 2,0 & 3,0 & 83,0 & 3,0 & 2,5 & $-0,7$ & 2,0 \\
\hline Honduras & 70,7 & 72,0 & 3,0 & 3,0 & 140,0 & 4,0 & 2,5 & $-1,2$ & 2,0 \\
\hline Nicarágua & 14,0 & 116,0 & 2,0 & 3,0 & 127,0 & 4,0 & 4,3 & $-0,7$ & 2,0 \\
\hline Venezuela & 49,0 & 66,0 & 3,0 & 3,0 & 160,0 & 5,0 & 2,8 & $-1,7$ & 2,0 \\
\hline Colômbia & 34,6 & 13,0 & 4,0 & 4,0 & 94,0 & 4,0 & 2,8 & $-0,4$ & 3,0 \\
\hline México & 17,7 & 60,0 & 2,0 & 4,0 & 106,0 & 3,0 & 2,9 & $-0,6$ & 3,0 \\
\hline Peru & 10,3 & 52,0 & 2,0 & 3,0 & 83,0 & 3,0 & 3,4 & $-0,6$ & 3,0 \\
\hline \multicolumn{10}{|c|}{$\begin{array}{l}\text { a - Taxa de homicídios por } 100 \text { mil habitantes. } \\
\text { b - O impacto do terrorismo no país por meio de uma média dos últimos cinco anos, pontuando de } 1 \text { (extremo impacto) para } 116 \text { (nenhum impacto). } \\
\text { c - Uma avaliação qualitativa da intensidade dos conflitos no interior do país, classificada entre } 1 \text { a } 5 \text { (muito baixo a muito alto). } \\
\text { d - Um índice que analisa a frequência, gravidade e a cumplicidade de risco em diferentes categorias de D.H., pontuando de } 1 \text { a } 4 \text { (baixo a extremo). } \\
\text { e - Um índice que reflete a pontuação de países em uma escala de } 0 \text { (muito corrupto) a } 100 \text { (muito limpo). } \\
\text { f - É uma conjunção de variáveis no qual a pontuação } 1 \text { indica o melhor grau de liberdade, e a pontuação } 7 \text { o pior grau. } \\
\text { g - Analisa em que medida o crime organizado impõe custos ao setor privado, variando de } 1 \text { (em grande medida) para } 7 \text { (nenhum custo). } \\
\text { h - Capta a percepção do grau em que os agentes têm confiança e respeitam as regras da sociedade, variando de cerca de }-2,5 \text { a } 2,5 \text { (pouca confiança a muita confiança). }\end{array}$} \\
\hline
\end{tabular}


Como estratégia de análise, para a criação do Índice Combinado de Crime e Justiça, e a consequente segmentação da amostra em distintos clusters foram estabelecidos quatro passos: o primeiro passo refere-se à recodificação das variáveis para que todas tivessem idêntica direção. Por exemplo, a variável que mede a presença de atividades terroristas no país é um ranking dos países classificados do país mais afetado ao menos afetado e foi invertida para a análise. A variável "Estado de Direito", por assumir valores negativos e positivos (de 2,5 a +2,5 sendo que os maiores valores no índice indicam um desempenho melhor do país), também foi recodificada.

O segundo passo foi a padronização das variáveis, isto é, as variáveis foram normalizadas. ${ }^{27}$ No terceiro passo calculou-se o alpha de Cronbach para avaliar a aditividade das variáveis consideradas com respeito à dimensão latente do índice que pretende medir a presença do crime organizado e a força do sistema de justiça criminal nos países. Como pode ser observado na tabela 1 a seguir, obtém-se um alpha de 0,912 com n=13 e 8 variáveis.

Tabela 2 - Cálculo do Alpha de Cronbach

\begin{tabular}{|ccc|}
\hline $\mathbf{N}^{\mathbf{0}}$ Casos & $\mathbf{N}^{\mathbf{0}}$ Variáveis & Alpha de Cronbach \\
\hline 13 & 8 & 0,912 \\
\hline \multicolumn{3}{|c}{ Fonte: Elaboração própria } \\
\hline
\end{tabular}

Importante apontar que todos os itens da escala apresentam correlação positiva menos no caso da relação entre terrorismo com a taxa de homicídios que não apresentaram correlação. O quarto e último passo consistiu no agrupamento dos casos com base no procedimento de "K mean clusters." 28

\footnotetext{
${ }^{27} \mathrm{z}=(\mathrm{X}-\mu) \sigma$

${ }^{28}$ A análise de cluster permite agrupar um conjunto de objetos em grupos (clusters) com base em algum critério de semelhança e de distância entre grupos. Trata-se de um procedimento exploratório que utiliza distintos algoritmos que diferem significativamente na identificação de vetores e na produção de agrupamentos. A análise de cluster foi realizada no software Stata com o procedimento chamado " $\mathrm{k}$ means", que considera a média das variáveis como critério de agrupamento.
} 
Tabela 3 - Número de casos em cada cluster e média da escala ICCJ segundo o cluster

\begin{tabular}{|l|l|l|}
\hline Cluster & Casos & Média Escala \\
\hline 1 & 4,00 & $-7,68$ \\
2 & 6,00 & 2,40 \\
3 & 3,00 & 3,89 \\
\hline Casos Válidos & $\mathbf{1 3 , 0 0}$ \\
\hline \multicolumn{2}{|c|}{ Fonte: Elaboração própria }
\end{tabular}

De acordo com a tabela 3, no cluster 1 estão os países de baixa criminalidade e com sistemas de justiça relativamente mais organizados e menos corruptos (Argentina; Chile; Costa Rica; e Uruguai). No segundo cluster encontram-se os países de alto nível de criminalidade, presença do crime organizado e com problemas de mau funcionamento dos no sistema de justiça (Belize; Brasil; El Salvador; Honduras; Nicarágua e Venezuela) e o terceiro cluster reúne os países com sérios problemas de segurança pública com a atuação de organizações criminosas e problemas estruturais no sistema de justiça (Colômbia; México e Peru).

Esta segmentação em clusters será levada em conta no momento da análise das diferenças na adoção das medidas penais pelos países segundo o pressuposto de que a presença do crime organizado afeta diretamente o contexto no qual os governos atuam diante do problema do tráfico de pessoas. A escolha pela divisão por clusters, além de conferir maior segurança no processo de comparação, contribui para aumentar a probabilidade de aceitação da hipótese nula do estudo.

Na próxima seção buscar-se-á analisar as ações dos países em relação ao Protocolo de Palermo. Assim, devido à natureza da pesquisa, serão analisados os dados oficiais que indicam se o país aderiu de maneira integral ou parcial, às diretrizes postas pela Convenção de Palermo.

\section{POLÍTICAS PÚblicas E PENAIS CONTRA O TRÁfiCO de PESSOAS}

Cada país pode soberanamente aderir ou não a determinado tratado internacional, bem como criar e modificar legislações que lhes pareçam melhores e se adaptem de maneira mais 
adequada a sua realidade como nação. No caso do tráfico internacional de seres humanos a premissa continua a mesma, sendo que qualquer país pode, voluntariamente, decidir por fazer parte da Convenção de Palermo e seus Protocolos e legislar sobre o tráfico da forma como acreditam ser mais acertado.

O objetivo desta seção é observar qual o posicionamento dos países selecionados para o enfrentamento ao tráfico de pessoas. Para tal é necessária uma análise dos países da amostra no que se refere ao seu posicionamento em relação ao Protocolo Relativo à Prevenção, Repressão e Punição do Tráfico de Pessoas, em Especial Mulheres e Crianças da Convenção de Palermo, além de um apontamento e breve descrição de suas atuais legislações destinados ao tema.

Ainda mais especificamente neste estudo de caso, serão levantadas informações sobre diversas dimensões que permitem avaliar o atual status de compliance dos treze países da amostra com o Protocolo de Palermo. Portanto, as dimensões analisadas para cada país serão: a) se houve a ratificação do Protocolo de Palermo relativo ao Tráfico de Pessoas; b) a data de ratificação ou aceite ao Protocolo; c) as normas produzidas; d) a data de criação destas normas locais; e) a pena máxima estabelecida para o crime de tráfico humano.

Os resultados analisados estão limitados pelo fato de que não foi possível realizar um levantamento do processo histórico de desenvolvimento das legislações nacionais referentes ao enfrentamento ao tráfico de pessoas. Contudo, é possível que normas anteriores tenham afetado de alguma forma as estratégias dos países no combate a este tipo de crime organizado.

Para todos os países em questão procurou-se utilizar a mesma metodologia de trabalho para o levantamento e apresentação dos dados. A pesquisa empírica buscou ter como fonte dados oficiais, sejam estes divulgados pelo Escritório das Nações Unidas sobre Drogas e Crimes (UNODC), ${ }^{29}$ ou por fontes oficiais dos países da amostra. Para detalhamento das informações obtidas, bem como das fontes visitadas ver o apêndice a este artigo.

\footnotetext{
29 Texto na íntegra disponível em: <https://treaties.un.org/Pages/ViewDetails.aspx?src=TREATY\&mtdsg_no=XVIII12a\&chapter=18\&lang=en>. Acesso em: 4 abr. 2014
} 
Tabela 4 - Políticas Públicas nas Américas sobre Tráfico de Pessoas

\begin{tabular}{|c|c|c|c|c|c|c|}
\hline \multirow{2}{*}{$\begin{array}{l}\text { Índice } \\
\text { Composto de } \\
\text { Crime e Justiça } \\
\end{array}$} & \multirow[b]{2}{*}{ PAÍS } & \multicolumn{2}{|c|}{ Ratificação Palermo } & \multicolumn{2}{|l|}{ Normas Produzidas } & \multirow{2}{*}{$\begin{array}{l}\text { PENA MÁXIMA } \\
\text { ESTABELECIDA }\end{array}$} \\
\hline & & SIM/NÃO & DATA & NORMAS & DATA & \\
\hline \multirow[t]{6}{*}{ 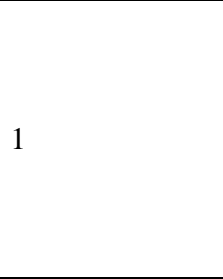 } & \multirow{2}{*}{ Argentina } & \multirow{2}{*}{ Sim } & \multirow{2}{*}{2002} & Lei 26.364 & 2008 & \multirow{2}{*}{15} \\
\hline & & & & Lei 26.842 & 2012 & \\
\hline & Chile & Sim & 2004 & Lei 20.507 & 2011 & 15 \\
\hline & \multirow{2}{*}{ Costa Rica } & \multirow{2}{*}{ Sim } & \multirow{2}{*}{2003} & Decreto Executivo 34.199 & 2005 & \multirow{2}{*}{20} \\
\hline & & & & Lei 9.095 & 2012 & \\
\hline & Uruguai & Sim & 2005 & Lei 18.250 & 2008 & 16 \\
\hline \multirow{9}{*}{2} & \multirow{2}{*}{ Belize } & \multirow{2}{*}{ Sim } & \multirow{2}{*}{2003} & Trafficking in Person Bill & 2003 & \multirow{2}{*}{25} \\
\hline & & & & Trafficking in Person Bill & 2013 & \\
\hline & Brasil & Sim & 2004 & Lei 11.106 & 2005 & 12 \\
\hline & El Salvador & Sim & 2004 & Decreto Legislativo 210 & 2004 & 8 \\
\hline & \multirow{2}{*}{ Honduras } & \multirow{2}{*}{ Sim } & \multirow{2}{*}{2008} & Decreto 234/2005 & 2005 & \multirow{2}{*}{15} \\
\hline & & & & Decreto 59/2012 & 2012 & \\
\hline & Nicarágua & Sim & 2004 & Lei 641 & 2007 & 14 \\
\hline & \multirow[b]{2}{*}{ Venezuela } & \multirow[b]{2}{*}{ Sim } & \multirow[b]{2}{*}{2002} & $\begin{array}{l}\text { Ley orgánica contra la } \\
\text { delincuencia organizada }\end{array}$ & 2005 & \multirow[b]{2}{*}{30} \\
\hline & & & & $\begin{array}{l}\text { Ley orgánica contra la } \\
\text { delincuencia organizada y } \\
\text { financiamiento al terrorismo }\end{array}$ & 2012 & \\
\hline \multirow{5}{*}{3} & Colômbia & Sim & 2004 & Lei 985 & 2005 & 23 \\
\hline & \multirow{3}{*}{ México } & \multirow{3}{*}{ Sim } & \multirow{3}{*}{2003} & $\begin{array}{l}\text { Ley para prevenir y sanciona } \\
\text { trata de personas }\end{array}$ & 2007 & \multirow{3}{*}{30} \\
\hline & & & & & & \\
\hline & & & & $\begin{array}{l}\text { Ley general para prevenir, } \\
\text { sancionar y erradicar(...) } \\
\text { trata de personas }\end{array}$ & 2012 & \\
\hline & Peru & Sim & 2002 & Lei 28.950 & 2007 & 25 \\
\hline
\end{tabular}

Fonte: Elaboração própria

Ao se analisar a tabela 4, fica evidente que todos os países da amostra ratificaram o Protocolo de Palermo, isto necessariamente indica que todos também ratificaram a convenção contra o crime organizado. Outro apontamento claro reside no fato de que todos os Estados, nas mais diversas medidas, tiveram a produção de alguma norma que endereçasse o tráfico de pessoas em seus ordenamentos jurídicos domésticos. Acrescente-se ainda que é possível identificar o tempo decorrido entre o momento em que o Protocolo de Palermo e sua ratificação pelos países varia bastante, num intervalo de dois até oito anos, ou seja, o tempo médio para a ratificação do Protocolo de Palermo na amostra é cerca de 3,6 anos. 
Quando analisado o tempo para se produzir uma norma pós-Convenção de Palermo entendendo este como o tempo decorrido entre a ratificação e a criação da primeira norma no país em questão depois da ratificação do tratado - o tempo médio é de 2,8 anos.

Quando se trata de crimes de tráfico de pessoas na amostra de países, a média da pena máxima que um criminoso pode ser condenado é cerca de dezenove anos, tendo uma variação da mínima de oito anos (El Salvador) até a máxima de trinta anos (México e Venezuela).

Ao se averiguar a tabela 4 encontram-se evidências da região que mostra interesse no combate ao tráfico de pessoas. Não apenas todos os países ratificaram a Convenção de Palermo, como também cada um deles, independentemente de sua posição em nosso Índice Composto de Crime e Justiça, criaram normas domésticas específicas, cuja finalidade é combater e mitigar o tráfico humano. O presente trabalho é limitado na medida em que não dispõe de comparações com outras regiões do mundo, os dados indicam, no entanto, que os países da região têm participado do esforço de transformar em norma doméstica o Protocolo de Palermo.

A seguir serão analisadas as informações levantadas em cada um dos grupos (clusters) obtidos com base no Índice Composto de Crime e Justiça (ICCJ).

\subsection{POLÍTICAS PÚBLICAS NOS PAÍSES DE ACORDO COM SEU ENQUADRAMENTO NO ICCJ}

Tabela 5 - Análise de Dados / ICCJ 1 (tempo em anos)

\begin{tabular}{|c|c|c|c|c|c|c|c|}
\hline & $\begin{array}{l}\text { Ano da } \\
\text { ratificação }\end{array}$ & $\begin{array}{l}\text { Tempo } \\
\text { para a } \\
\text { ratificação }\end{array}$ & $\begin{array}{l}\text { Média do } \\
\text { tempo de } \\
\text { ratificação } \\
\text { ICCJ } 1\end{array}$ & $\begin{array}{l}\text { Tempo } \\
\text { produção } \\
\text { da norma }\end{array}$ & $\begin{array}{l}\text { Média do } \\
\text { tempo de } \\
\text { produção } \\
\text { da norma } \\
\text { ICCJ } 1\end{array}$ & $\begin{array}{l}\text { Pena } \\
\text { máxima }\end{array}$ & $\begin{array}{l}\text { Média } \\
\text { da Pena } \\
\text { máxima } \\
\text { ICCJ } 1\end{array}$ \\
\hline Argentina & 2002 & 2,0 & \multirow{3}{*}{3,5} & 6,0 & \multirow{3}{*}{4,5} & 15,0 & \multirow{3}{*}{16,5} \\
\hline Costa Rica & 2003 & 3,0 & & 2,0 & & 20,0 & \\
\hline Uruguai & 2005 & 5,0 & & 3,0 & & 16,0 & \\
\hline
\end{tabular}

Na tabela 5 pode-se apontar que o tempo médio do cluster ICCJ 1 para ratificação do Protocolo de 3,5 anos é similar ao tempo médio da amostra de 3,6 anos. Ao passo que para se produzir normas o tempo médio de 4,5 anos relativamente acima da média amostral de 2,8. 
No que se refere à pena máxima, a média dos treze países da amostra é ligeiramente superior - 19,9 anos -, se comparada à média do cluster 1 - 16,5 anos -, tendo em vista que as penas máximas apresentadas pelos quatro países são relativamente menores.

Tabela 6 - Análise de Dados / ICCJ 2 (tempo em anos)

\begin{tabular}{|llllllll|}
\hline & $\begin{array}{l}\text { Ano da } \\
\text { ratificação }\end{array}$ & $\begin{array}{l}\text { Tempo } \\
\text { para a } \\
\text { ratificação }\end{array}$ & $\begin{array}{l}\text { Média do } \\
\text { tempo de } \\
\text { ratificação } \\
\text { ICCJ 2 }\end{array}$ & $\begin{array}{l}\text { Tempo } \\
\text { para } \\
\text { produção } \\
\text { da norma }\end{array}$ & $\begin{array}{l}\text { Média do } \\
\text { tempo de } \\
\text { produção } \\
\text { da norma } \\
\text { ICCJ 2 }\end{array}$ & $\begin{array}{l}\text { Pena } \\
\text { máxima }\end{array}$ & $\begin{array}{l}\text { Média da } \\
\text { menáxima } \\
\text { ICCJ 2 }\end{array}$ \\
\hline Belize & 2003 & 3,0 & & 0,0 & & 25,0 & \\
Brasil & 2004 & 4,0 & & 1,0 & & 12,0 & \\
El Salvador & 2004 & 4,0 & 4,2 & 0,0 & 0,7 & 8,0 & 15,0 \\
Honduras & 2008 & 8,0 & & $-3,0$ & & 14,0 & \\
Nicarágua & 2004 & 4,0 & & 3,0 & & 30,0 & \\
Venezuela & 2002 & 2,0 & & 3,0 & & & \\
\hline
\end{tabular}

Fonte: Elaboração própria

Ao se analisar a tabela 6 pode-se ver que o tempo médio desse cluster - ICCJ 2 - para ratificação do Protocolo, com 4,2 anos, está acima do tempo médio da amostra $(3,6)$. Contudo, há agilidade no processo de produção de normas, tendo em vista que aqui o tempo médio é menos de 1 ano $(0,7)$ em face da média amostral de 2,8 anos. No que se refere à pena máxima, a média de 17,3 anos do cluster está abaixo da média amostral $(19,9)$.

Tabela 7 - Análise de Dados / ICCJ 3 (tempo em anos)

\begin{tabular}{|llllllll|}
\hline & $\begin{array}{l}\text { Ano da } \\
\text { ratificação }\end{array}$ & $\begin{array}{l}\text { Tempo } \\
\text { para a } \\
\text { ratificação }\end{array}$ & $\begin{array}{l}\text { Média do } \\
\text { tempo de } \\
\text { ratificação } \\
\text { ICCJ 3 }\end{array}$ & $\begin{array}{l}\text { Tempo } \\
\text { para } \\
\text { produção } \\
\text { da norma }\end{array}$ & $\begin{array}{l}\text { Média do } \\
\text { tempo de } \\
\text { produção } \\
\text { da norma } \\
\text { ICCJ 3 }\end{array}$ & $\begin{array}{l}\text { Pena } \\
\text { máxima }\end{array}$ & $\begin{array}{l}\text { Média da } \\
\text { Pena } \\
\text { máxima } \\
\text { ICCJ 3 }\end{array}$ \\
\hline Colômbia & 2004 & 4,0 & & 1,0 & & 23,0 & \\
México & 2003 & 3,0 & 3,0 & 4,0 & 3,3 & 30,0 & 26,0 \\
Peru & 2002 & 2,0 & & 5,0 & & 25,0 & \\
\hline
\end{tabular}

Fonte: Elaboração própria

Por meio da tabela 7 é possível apontar que o tempo médio do cluster ICCJ 3 para ratificação do Protocolo de 3 anos está abaixo ao tempo médio da amostra $(3,6)$. Ao passo que para se produzir normas o tempo médio de 3,3 anos fica acima da média amostral $(2,8)$. No que se refere à pena máxima, a média da amostra é consideravelmente inferior (19,9 anos), se comparada à média do cluster em questão (26 anos). 
Pelas tabelas 5, 6 e 7 observa-se que os clusters possuem comportamentos distintos, evidenciados por intermédio de suas médias para o tempo de ratificação, para o tempo de produção da norma e de penas máximas. Porém, esses recortes são insuficientes para afirmar que o nível prévio de presença do crime organizado e o desenvolvimento do sistema de justiça diferencia claramente o comportamento dos países da amostra no que se refere às normas produzidas domesticamente. Assim, em relação à grande parte das variáveis levantadas na pesquisa empírica, não é possível apontar nenhum padrão claro no comportamento dos países de acordo com seu posicionamento no Índice Composto de Crime e Justiça, sendo a única exceção a variável de Penas Máximas estabelecidas.

Figura 1 - Gráfico de Dispersão dos países de acordo com o ICCJ e Penas Máximas estabelecidas

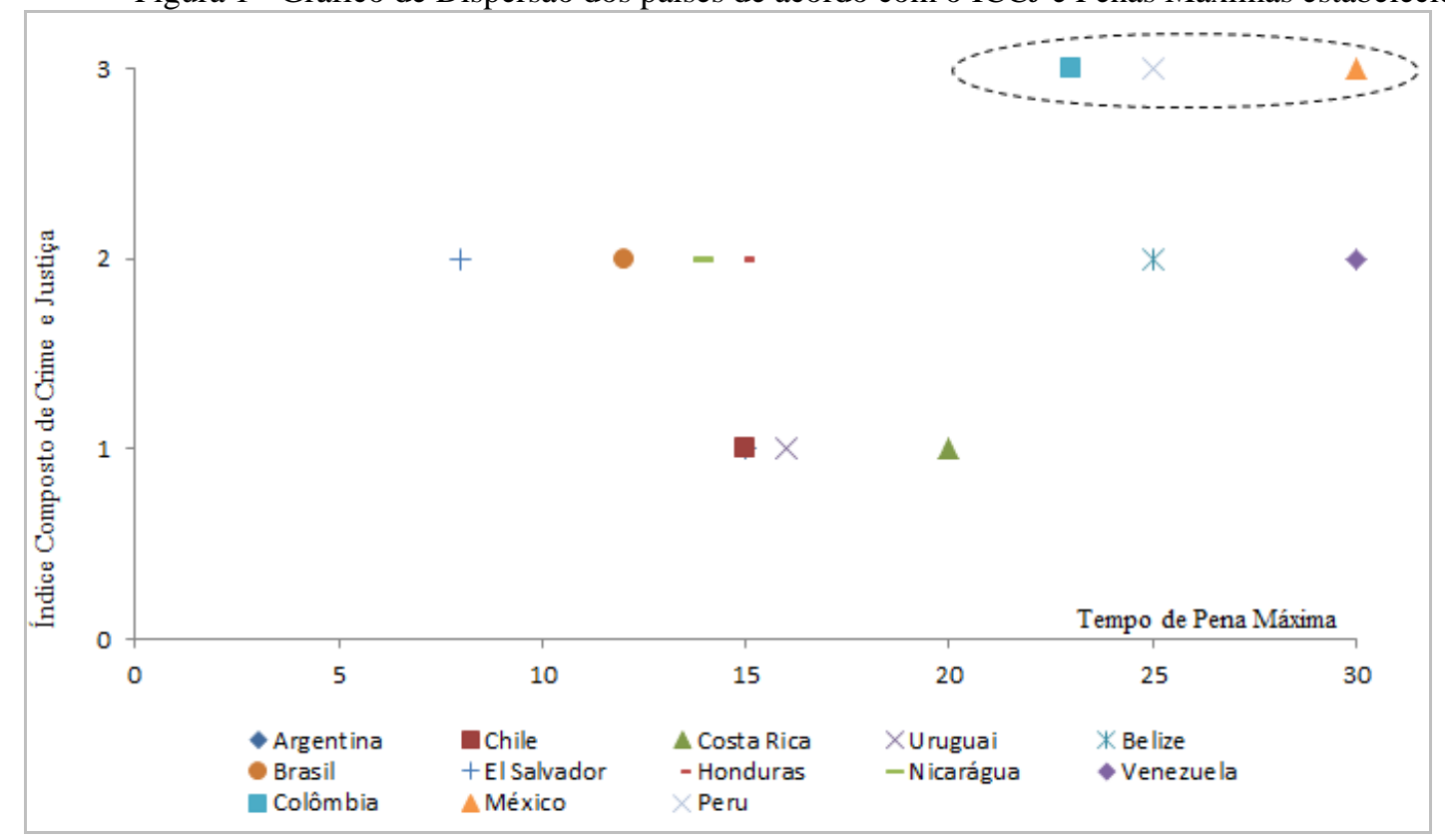

Fonte: Elaboração própria

Por meio do gráfico de dispersão depreende-se que aqueles países enquadrados no ICCJ 3 (Colômbia, México e Peru), isto é, os países que mais sofrem com a questão do crime e o comprometimento do sistema de justiça são aqueles que estabelecem as maiores penas da região. É possível, então, assinalar que, na amostra de países considerados, quanto maior a 
incidência do crime organizado e de atividades ilícitas sobre o sistema de justiça maiores tendem a ser as penas criadas no contexto do combate ao tráfico internacional de pessoas.

\section{COMPLIANCE AO ENFRENTAMENTO AO TRÁFICO DE PESSOAS}

$\mathrm{Na}$ presente seção, serão explorados os resultados obtidos a partir das mudanças realizadas pelos treze países que compõem a amostra. Assim, três indicadores de compliance ao enfrentamento ao tráfico humano na região das Américas serão colocados: o panorama do país em questão pela óptica do Trafficking in Person Report; o posicionamento atual do país em relação ao Global Slavery Index; e um resumo dos casos levantados junto ao Human Trafficking Case Law Database.

O Trafficking in Person Report é uma publicação que trata do vínculo existente entre tráfico internacional de pessoas e compliance com normas globais, sendo um relatório com periodicidade anual, publicado pelo Departamento de Estado estadunidense. Para a classificação dos países, o relatório se utiliza de uma segmentação em camadas - ou Tiers. Enquanto a camada/Tier 1 representa o mais alto padrão, a camada/Tier 4 representa o padrão menos desenvolvido. ${ }^{30}$

No que se refere ao Global Slavery Index, índice desenvolvido pela ONG Walk Free Foundation, cataloga da seguinte maneira: o $1^{\circ}$ lugar é a pior posição enquanto o $162^{\circ}$ lugar refere-se à melhor posição do ranking. Baseia-se em uma medida combinada de três fatores: a prevalência estimada de escravidão moderna pela população, a mensuração do casamento infantil no país, e uma mensuração de tráfico de seres humanos que entra e sai do país em questão ${ }^{31}$.

Por sua vez, o Human Trafficking Case Law Database ${ }^{32}$ é uma base de dados da ONU, desenvolvida e alimentada pelo escritório do UNODC. Representa uma iniciativa online para criar um banco de dados global de decisões judiciais acerca de casos de tráfico humano. Por meio desta base de dados serão analisados casos de indivíduos que tenham sido

\footnotetext{
30 Para informações mais detalhadas acerca do Trafficking in Person Report, acessar: http://www.state.gov/j/tip/rls/tiprpt/.

31 Para informações mais detalhadas acerca do Global Slavery Index, acessar: http://www.globalslaveryindex.org/explore/

${ }^{32}$ Para informações mais detalhadas acerca do Human Trafficking Case Law Database, acessar:

http://www.unodc.org/cld/index.jspx
} 
acusados/julgados pela legislação doméstica do país da amostra em questão no que concerne ao crime de tráfico internacional de pessoas. O presente trabalho demonstrará dados que abrangem todo o espaço temporal que a base de dados oferece, sendo que cada país apresenta um número singular ${ }^{33}$ de casos. Ao tratar deste recorte temporal há uma interessante base de análise, visto que esta abrange alguns anos antes e depois da entrada em vigor da Convenção de Palermo e seus Protocolos na legislação interna do país, ou seja, o antecedente e o resultado de alguma mudança na legislação nacional do país em análise. Assim, serão levantados o número de $\operatorname{casos}^{34}$ antes e depois da entrada em vigor no país da legislação específica contra o tráfico humano, tendo sempre um ano base como o divisor entre o antes e o depois da mudança na legislação penal. Assim, se possuirá uma base comparativa relevante para a análise de compliance do país em relação à Convenção de Palermo. Ao trazer o Human Trafficking Case Law Database é possível observar se houve um reflexo no número de indivíduos efetivamente julgados por esse crime no país, depois da entrada em vigor do Protocolo de Palermo.

Para um detalhamento dos dados obtidos e uma análise mais abrangente das informações colhidas no Trafficking in Person Report, bem como dos elementos ponderados no Human Trafficking Case Law Database (os anos base tomados como divisores nas análises) ver apêndice a este artigo.

Tabela 8 - Indicadores de Compliance ao Enfrentamento ao Tráfico Humano nas Américas

\begin{tabular}{|c|c|c|c|c|c|}
\hline \multirow[b]{2}{*}{$\begin{array}{l}\text { Índice Composto } \\
\text { Crime e Justiça }\end{array}$} & \multirow[b]{2}{*}{ País } & \multirow[b]{2}{*}{$\begin{array}{l}\text { Trafficking in } \\
\text { Person Report }\end{array}$} & \multirow[b]{2}{*}{$\begin{array}{l}\text { Global } \\
\text { Slavery Index } \\
2014\end{array}$} & \multicolumn{2}{|c|}{ Human Trafficking Case Law Database } \\
\hline & & & & $\begin{array}{l}\mathrm{N}^{\mathrm{o}} \text { casos julgados } \\
\text { antes da mudança na } \\
\text { legislação } \\
\text { Ano variável de } \\
\text { acordo com cada } \\
\text { país }\end{array}$ & $\begin{array}{l}\text { No casos julgados } \\
\text { depois da mudança na } \\
\text { legislação } \\
2014\end{array}$ \\
\hline \multirow{4}{*}{1} & Argentina & Tier 2 & 122 & 0 & 68 \\
\hline & Chile & Tier 2 & 89 & 3 & 1 \\
\hline & Costa Rica & Tier 2 & 146 & 2 & 0 \\
\hline & Uruguai & Tier 2 - Watching List & 72 & - & - \\
\hline 2 & Belize & Tier 2 & - & 0 & 3 \\
\hline
\end{tabular}

\footnotetext{
${ }^{33}$ Nesta base de dados todos os países da amostra possuem casos que são refletidos nesse artigo, com exceção de Honduras, México e Uruguai. Porém, há países em que o número de casos são bastante reduzidos, como o caso da Venezuela (apenas um caso na base de dados), limitando a analise comparativa temporal.

${ }^{34}$ Nas análises é levado em consideração o ano do veredicto, não da sentença; também foram excluídos casos considerados "retirados/withdrawn".
} 


\begin{tabular}{|llllll|}
\multirow{4}{*}{ Brasil } & Tier 2 & 94 & 7 & 64 \\
El Salvador & Tier 2 & 95 & 0 & 6 \\
Honduras & Tier 2 - Watching List & 110 & - & - \\
Nicarágua & Tier 1 & 108 & 0 & 6 \\
Venezuela & Tier 2 - Watching List & 75 & 0 & 1 \\
\hline \multirow{3}{*}{ Colômbia } & Tier 1 & 73 & 4 & 14 \\
& México & Tier 2 & 107 & - & 6 \\
\hline
\end{tabular}

Fonte: Elaboração própria

Ao analisar a tabela 8, o destaque fica por conta da Nicarágua e da Colômbia, únicos dois países da amostra a serem classificados no Tier 1, ao passo que as piores colocações ficam com o Uruguai, Honduras e Venezuela, estando classificadas no Tier 2 - Watching List. Aqui também não é possível apontar uma correspondência de acordo com o enquadramento no ICCJ e o compliance dos países de acordo o Trafficking in Person Report, tendo em vista que países como o Uruguai (ICCJ 1) são mal classificados, ao passo que Colômbia (ICCJ 3) está entre os melhores classificados de acordo com o relatório. No entanto, ao explorar os dados a partir do nível agregado dos clusters, podem-se fazer alguns apontamentos:

Tabela 9 - Análise dos indicadores de compliance

\begin{tabular}{|cccc|}
\hline & Global Slavery Index & $\begin{array}{l}\text { Human Trafficking Case Law Database } \\
\text { No Casos Julgados antes da }\end{array}$ & $\begin{array}{l}\mathrm{N}^{\circ} \text { Casos Julgados antes da } \\
\text { mudança na legislação }\end{array}$ \\
$\begin{array}{l}\text { Índice Composto } \\
\text { de Crime e Justiça }\end{array}$ & Média da Posição & $\begin{array}{l}\text { Tudança na legislação } \\
\text { muda }\end{array}$ & 69,0 \\
\hline 1 & 107,0 & 5,0 & 80,0 \\
2 & 96,4 & 7,0 & 20,0 \\
3 & 81,7 & 5,0 & 169,0 \\
\hline
\end{tabular}

Fonte: Elaboração própria

É legítimo apontar que dentre os indicadores comparados, no que se refere ao Global Slavery Index, o cluster ICCJ 1 é o melhor posicionado, seguido pelo ICCJ 2 e finalizado pelo cluster ICCJ 3.

Quanto ao Human Trafficking Case Law Database o número de casos julgados, antes da produção de normas específicas ao tráfico humano, pode-se apontar que o cluster ICCJ 2, mesmo que timidamente, dentre a amostra era o que mais estava atento para a questão, com 
sete casos julgados, ao passo que os outros dois cluster impunham menos esforços nesse quesito. Uma vez produzida à norma, o número de casos julgados aumenta exponencialmente em toda a região das Américas, saindo de 17 casos julgados ao total para 169 casos julgados na região. O cluster ICCJ 2 continua se mostrando como o que mais empenha esforços neste sentido (80 casos), seguido do ICCJ 1 (69), porém ambos bastante distantes do cluster ICCJ 3, com apenas 20 casos julgados.

Assim, por meio deste recorte analítico pode-se demonstrar os países que mais recebem a carga da criminalidade e possuem sistemas de justiça pouco desenvolvidos tendem a ser àqueles na região que menos apresentam casos efetivamente julgados no combate ao tráfico de pessoas, mesmo depois da adoção de leis específicas no âmbito doméstico.

Além dos indicadores de compliance que aqui foram levantados, outra maneira de mensurar os resultados que os países têm obtido é por meio da mobilização institucional que cada Estado tem apresentado. Dessa maneira, foram levantados dados acerca de grandes ações em âmbito nacional que cada um dos países tem realizado, cobrindo o espaço temporal desde a entrada em vigor da Convenção de Palermo (2000) até meados de 2014. Para informações mais detalhadas acerca da criação de cada iniciativa, ver apêndice a este artigo.

A tabela 10 traz as iniciativas levantadas para cada um dos países ${ }^{35}$ que compõem o Índice Composto de Crime e Justiça. Por motivos didáticos categorizou-se as iniciativas em três eixos centrais: ${ }^{36}$ 1) "Prevenção e Responsabilização"; 2) "Integração de Instituições Nacionais"; e 3) "Comunicação". O $1^{\text {o }}$ eixo diz respeito às iniciativas que lidam com o aperfeiçoamento do marco regulatório para fortalecer o enfrentamento ao tráfico de pessoas. O $2^{\circ}$ eixo categoriza a integração e o fortalecimento das políticas públicas, redes de atendimento e organizações para prestação de serviços necessários ao enfrentamento ao tráfico de pessoas. E o $3^{\circ}$ eixo refere-se à produção, gestão e disseminação de informação e conhecimento sobre tráfico de pessoas, bem como a campanhas para o enfrentamento a este crime.

\footnotetext{
${ }^{35}$ Ainda que a pesquisa realizada tenha sido extensiva, ressalta-se que uma iniciativa ou outra pode não estar presentes na tabela 10 , por motivos didáticos e/ou por falta de dados nas fontes pesquisadas.

${ }^{36}$ Para a categorização, tomou-se como base o II Plano Nacional de Enfrentamento ao Tráfico de Pessoas, do Ministério da Justiça Federal Brasileira, porém foram realizadas adaptações didáticas pelo próprio autor. Disponível em: <http://portal.mj.gov.br/main.asp?View=\{E8833249-5827-4772-BDC6D7F1D880AD41 $\} \& B r o w s e r T y p e=I E \& L a n g I D=p t-b r \& p a r a m s=i t e m I D \% 3 D \% 7 B B 5014675-B 763-4282-891 \mathrm{~A}-$ 784E0688387A\%7D\%3B\&UIPartUID=\%7B2868BA3C-1C72-4347-BE11-A26F70F4CB26\%7D.> Acesso em: 4 out. 2014.
} 
Tabela 10 - Mobilização Institucional para o Enfrentamento ao Tráfico de Pessoas, 2000-2014

\begin{tabular}{|c|c|c|c|c|}
\hline $\begin{array}{l}\text { Índice } \\
\text { Composto } \\
\text { Crime e Ju }\end{array}$ & $\begin{array}{l}\text { País / Eixos } \\
\text { Centrais }\end{array}$ & $\begin{array}{l}\text { Prevenção e } \\
\text { Responsabilização }\end{array}$ & $\begin{array}{l}\text { Integração de Instituições } \\
\text { Nacionais }\end{array}$ & Comunicação \\
\hline \multirow{4}{*}{1} & Argentina & $\begin{array}{l}\text { Conselho Federal e um Comitê } \\
\text { Executivo para a Luta contra o } \\
\text { Tráfico e Exploração de Pessoas e a } \\
\text { Proteção e Assistência as Vítimas }\end{array}$ & $\begin{array}{l}\text { Procuraduría de trata y explotar } \\
\text { de personas }\end{array}$ & - \\
\hline & Chile & $\begin{array}{l}\text { Plan Nacional Contra la Trata de Persona } \\
\text { Chile }\end{array}$ & & - \\
\hline & Costa Rica & - & $\begin{array}{l}\text { Coalición Nacional Contra el T } \\
\text { Ilícito de Migrantes y Trata de } \\
\text { Personas }\end{array}$ & - \\
\hline & Uruguai & - & - & - \\
\hline \multirow{6}{*}{2} & Belize & $\begin{array}{l}\text { Plan estratégico nacional antitráfico } \\
\text { 2012-2014 }\end{array}$ & $\begin{array}{l}\text { Intergovernmental agengy } \\
\text { task force on trafficking in } \\
\text { persons - Una comisión } \\
\text { antitráfico de } 12 \text { agencias y } \\
\text { ONGs }\end{array}$ & - \\
\hline & Brasil & $\begin{array}{l}\text { Plano de Ações contra o Tráfico de } \\
\text { Pessoas; Política Nacional de } \\
\text { Enfrentamento ao Tráfico de } \\
\text { Pessoas; I e II Planos Nacionais de } \\
\text { Enfrentamento ao tráfico de pessoas }\end{array}$ & $\begin{array}{l}\text { Reuniões Técnicas } \\
\text { Nacionais }\end{array}$ & $\begin{array}{l}\text { Núcleos Especializados } \\
\text { no } \\
\text { enfrentamento } \\
\text { ao tráfico } \\
\text { humano }\end{array}$ \\
\hline & El Salvador & Política nacional contra la Trata de Persol & $\begin{array}{l}\text { Consejo Nacional contra la } \\
\text { Trata de Personas }\end{array}$ & - \\
\hline & Honduras & - & $\begin{array}{l}\text { Comisión Interinstitucional } \\
\text { contra la Explotación Sexual } \\
\text { Comercial y Trata de Personas } \\
\text { Honduras }\end{array}$ & $\begin{array}{l}\text { Campaña } \\
\text { Nacional } \\
\text { contra la } \\
\text { Trata de } \\
\text { Personas } \\
\end{array}$ \\
\hline & Nicarágua & - & - & - \\
\hline & Venezuela & - & - & - \\
\hline \multirow{3}{*}{3} & Colômbia & $\begin{array}{l}\text { Estrategia Nacional Contra la } \\
\text { Trata de Personas }\end{array}$ & $\begin{array}{l}\text { Comité Interinstitucional } \\
\text { para la lucha contra } \\
\text { la Trata de Personas }\end{array}$ & $\begin{array}{l}\text { Sistema } \\
\text { Nacional de Información } \\
\text { sobre Trata de Personas }\end{array}$ \\
\hline & México & $\begin{array}{l}\text { Programa Nacional par Prevenir y Sancio } \\
\text { Trata de Personas }\end{array}$ & $\begin{array}{l}\text { Grupo de Trabajo multissetoria } \\
\text { permanente contra la trata de } \\
\text { personas }\end{array}$ & $\begin{array}{l}\text { Sistema de Registro y } \\
\text { Estadística del delito de } \\
\text { de personas y afines }\end{array}$ \\
\hline & Peru & - & & \\
\hline
\end{tabular}

Fonte: Elaboração própria 
A tabela 10 demonstra que, de maneira geral, a região possui outras instâncias de mobilização sem se restringir à questão de criação de normas domésticas no que se refere ao enfrentamento ao tráfico de pessoas. A criação de diversos planos nacionais, comitês e programas de prevenção e combate ao tráfico humano não se mostra como uma peculiaridade de um cluster ou outro. É possível identificar iniciativas nos três distintos eixos de categorização tanto no ICCJ 1, 2 e 3. Todavia, pode-se apontar como destaque que os únicos três países que apresentam mobilização nos três eixos simultaneamente são Brasil, Colômbia e México. Outro destaque que também pode ser apontado é em relação aos clusters: no ICCJ 1, aparentemente nenhuma grande mobilização na questão de comunicação foi realizada; enquanto que no ICCJ 3 é o que, relativamente, mais apresenta iniciativas, sendo um indício de que quanto mais permeado o país está do crime organizado mais iniciativas de mobilização nacional tende a ter.

\section{CONSIDERAÇÕES FINAIS}

Este trabalho teve como objeto de pesquisa empírica o tráfico internacional de pessoas e suas implicações nas políticas públicas de países das Américas. O tráfico humano foi abordado sob uma óptica das relações internacionais com foco no principal marco legal ao seu enfrentamento, isto é, a Convenção de Palermo e seu Protocolo Adicional, mais precisamente a Convenção das Nações Unidas Contra o Crime Transnacional e seu Protocolo Relativo à Prevenção, Repressão e Punição do Tráfico de Pessoas, em Especial Mulheres e Crianças, ambos datados de 2000.

Buscou-se analisar como este tratado internacional influenciou na mudança das políticas públicas de segurança de treze países selecionados das Américas. Um dos objetivos da pesquisa foi o de descrever qual o compliance que os Estados possuem com as normas globais. Por isso, foram levantados os principais esforços nestes países, no que se refere à matéria da ratificação do Protocolo de Palermo, as normas produzidas internamente e as penas máximas estabelecidas por cada um dos países selecionados.

Para que se obtivesse uma melhor análise comparativa dos dados encontrados foi criado o Índice Composto de Crime e Justiça (ICCJ) dividindo os treze países da amostra em 
três distintos clusters - que espelhasse a influência doméstica do crime organizado e do sistema de justiça. Inicialmente a divisão em clusters pretendia apresentar uma forte correlação entre os níveis de criminalidade organizada e força do sistema de justiça criminal e as políticas públicas de fato adotadas. A primeira conclusão por meio da pesquisa empírica é a de que todos os treze países da amostra ratificaram o Protocolo de Palermo e todos empreenderam esforços na criação de normas domésticas específicas para o enfrentamento ao tráfico internacional de pessoas, sendo que cada país possui uma lei relacionada ao tráfico humano.

Outra dedução interessante foi a questão de que em relação a grande parte das variáveis levantadas na pesquisa empírica, poucas foram as correlações claras no comportamento dos países de acordo com seu posicionamento no Índice Composto de Crime e Justiça, isto é, apesar dos três diferentes clusters possuírem características distintas, a posição do país no cluster e suas políticas públicas de fato adotadas não mostraram uma interdependência direta forte.

Contudo, pelas análises baseadas na divisão dos clusters algumas conclusões mais específicas - e mais contundentes - puderam ser desenhadas. Assim, nota-se que as principais conclusões desta pesquisa foram: 1) É possível apontar que, nas Américas, quanto pior as experiências prévias em relação à incidência do crime organizado e de atividades ilícitas (ICCJ 3), maiores tendem a ser as penas máximas criadas no contexto do combate ao tráfico internacional de pessoas; 2) É legítimo assinalar que os países que mais estão sujeitos a má influência do crime organizado e estão permeados por um sistema de justiça comprometido (ICCJ 3), tendem a ser aqueles na região que menos apresentam casos efetivamente julgados no combate ao tráfico de pessoas, mesmo depois de serem criadas leis específica no âmbito doméstico que facilite o país a fazê-lo; 3) Há indícios de que quanto mais permeado o país está do crime organizado e mais comprometido seu sistema de justiça criminal mais iniciativas de mobilização nacional ele tende a criar.

Outra conclusão relevante do estudo é a análise da correlação do nível de compliance do país com o nível de criminalidade medido pelo Índice Composto de Crime e Justiça (ICCJ). O quadro 1 foi construído a partir de sete dimensões da presente pesquisa empírica, sendo elas: 1) Tempo para ratificação do Protocolo de Palermo; 2) Tempo para a produção da norma interna; 3) Pena máxima estabelecida; 4) Posição no Trafficking in Person Report; 5) 
Posição no Global Slavery Index; 6) Número de casos julgados presentes no Human Traffckig Case Law Database; 7) Indicativo de mobilização institucional para o enfrentamento ao tráfico de pessoa.

\begin{tabular}{l} 
Clust $\begin{array}{l}\text { Quadro 1 - Compliance com Normas em Tráfico de Pessoas } \\
\text { ICC }\end{array}$ \\
\cline { 2 - 4 }
\end{tabular}

Fonte: Elaboração própria

Como estratégia de análise, para a criação do quadro 1 foram estabelecidos quatro passos. Enquanto o primeiro passo foi a padronização das variáveis para que todas estivessem normalizadas, ${ }^{37}$ no segundo passo consistiu em criar um indicador agregado de todas as sete dimensões de análise - Indicador de Compliance com Normas em Tráfico de Pessoas. No terceiro passo calculou-se os três quartis de cada cluster do ICCJ, de acordo com o indicador agregado. O quarto passo avaliou a distribuição dos países de acordo com os quartis. Para mais detalhes da estratégia de análise ver tabela em apêndice a este artigo.

De acordo com o quadro 1 pode-se concluir que Argentina, Belize e El Salvador, e Colômbia são os países que apresentam melhor grau de compliance com as normas internacionais de tráfico de pessoas dentro do universo comparativo de países das Américas de acordo com o nível de incidência de problemas criminais e do funcionamento do sistema de justiça.

Outros apontamentos igualmente válidos que se pode inferir do quadro 1 são questões específicas como o fato do Brasil estar exatamente ao meio do quadro, sendo este um retrato

\footnotetext{
37 Para melhor análise comparativa, além da padronização de todas as dimensões, o componente de casos julgados presentes no Human Traffckig Case Law Database sofreu, para cada país, normalização de acordo com sua população.
} 
de seu alto nível de criminalidade e presença do crime organizado e com problemas de mau funcionamento no sistema de justiça e a evidenciação de que seu grau de compliance ainda é regular. Nomeadamente o Brasil possui como referências negativas as nações Honduras, Nicarágua e Venezuela, ao passo em que Belize e El Salvador são modelos exemplares com relação aos esforços no enfrentamento ao crime do tráfico humano.

Outro ponto interessante é a ocorrência do Uruguai, apesar de ser um país pouco permeado pelo crime organizado e possuir um sistema de justiça mais robusto, apresenta pouco esforço institucional no enfrentamento ao tráfico de pessoas. Ao passo que a Colômbia, em uma posição inversa, embora sujeita à forte influência do crime organizado e um sistema de justiça comprometido, possui comprometimento com o combate ao tráfico internacional de pessoas (alto nível de compliance com normas internacionais da matéria). Conclui-se, assim, que as ações iniciadas pela Colômbia devem ser tomadas como modelo por países da região com experiências prévias semelhantes com o crime organizado (México e Peru). De maneira semelhante, países enquadrados no ICCJ 1 e 2, que apresentam grau de compliance "Baixo" e "Médio" devem tomar como referência àqueles que estão emoldurados no nível "Alto" de compliance.

O presente trabalho é limitado no que diz respeito a recomendações para que haja "movimentações verticais" no quadro 1. Todavia, por meio das pesquisas empíricas realizadas, é possível afirmar que países à direita do quadro 1 podem ser tomados como referências positivas no que diz respeito ao compliance de enfretamento ao tráfico internacional de seres humanos.

O tráfico internacional de seres humanos representa uma questão presente e viva nas relações internacionais neste início do século XXI. O debate acerca desta temática é dinâmico e pouco explorado, encontra-se, simultaneamente, no âmbito das discussões dos Direitos Humanos e do sistema criminal e das políticas públicas. Por meio da presente pesquisa fica evidente a correlação do tráfico humano com outras agendas do crime organizado e as atividades ilícitas praticadas por eles. No entanto, cumpre dizer que as conclusões são limitadas, no que se refere a apontar quais as causas e consequências, ou mesmo qual a relação direta entre o crime organizado e a incidência na taxa de pessoas traficadas, sendo questões pertinentes a futuras pesquisas. 
Um eficiente combate ao tráfico internacional de pessoas deve primeiramente ser vislumbrado a partir da multidisciplinariedade, no qual o entendimento de que se trata de uma questão que envolve Direitos Humanos, sistema criminal e criação de políticas públicas é primordial. Tendo em vista as múltiplas correlações que as atividades criminosas impõem, será apenas por meio de múltiplas dimensões de atuação que se terá um efetivo enfrentamento ao tráfico humano. 


\section{BIBLIOGRAFIA}

CARNEIRO, L. P. Ameaça do Crime Organizado à Segurança Pública no Brasil. Revista Interesse Nacional, v. 3, n. 10, 2010.

FILHO, A. P.; VAZ, A. C. O Brasil no contexto do narcotráfico internacional. Revista Brasileira de Política Internacional, v. 1, n. 40, p. 75-122, 1997.

FREEDOM HOUSE. Freedom in the World 2014. Disponível em: <http://www.freedomhouse.org/report/freedom-world/freedom-world-2014\#>. Acesso em: 20 ago. 2014.

FORST, B. Terrorism, Crime and Public Policy. New York: Cambridge University Press, 2009.

HEIJDEN, J. Selecting Cases and Inferential Types in Comparative Public Policy. In: EGELI, I.; ALLISON, C. R. Comparative Policy Studies. Hampshire, ECPSR \& Palgrave Macmillan, v. 1, p. 35-56, 2013.

INSTITUTE FOR ECONOMICS AND PEACE. Global Terrorism Index - Capturing the impact of terrorism for the last decade, 2011. Disponível em:

<www.economicsandpeace.org>. Acesso em: 20 ago. 2014.

INSTITUTE FOR ECONOMICS AND PEACE. Global Peace Index. Disponível em: <www.economicsandpeace.org>. Acesso em: 20 ago. 2014.

KAUFMANN, D.; AART, K.; MASSIMO, M. The Worldwide Governance Indicators: Methodology and Analytical Issues, 2010. World Bank Policy Research Working Paper No. 5430, 2010.

KRAUSE, K.; WILLIAMS, M. C. Broadening the Agenda of Security Studies: Politics and Methods. Mershon International Studies Review, v. 40, p. 229-254, 1996.

MERRYMAN, J. H.; PERDOMO, R. P. The Civil Law Tradition: An Introduction to the Legal Systems of Europe and Latin America. Standford: Stanford University Press, 2007.

NAÍM, M. Ilícito: o ataque da pirataria, da lavagem de dinheiro e do tráfico à economia global. Rio de Janeiro: Jorge Zahar Editores, 2006. 
NORTH, D. Institutions, Institutional Change and Economic Performance. The Journal of Economic Perspectives, v. 5, n. 1, p. 97-112, 1991.

ORGANIZACIÓN DE LOS ESTADOS AMERICANOS. Informe sobre Seguridad Ciudadana en las Américas. 2012. Disponível em:

<http://www.oas.org/dsp/espanol/cpo_observatorio_alertamerica2012.asp>. Acesso em: 26 fev. 2014.

PRZEWORSKI, A.; TEUNE, H. Logic of Comparative Social Inquiry. New York: Krieger Publication, 1982.

PIOVESAN, F.; KAMIMURA, A. Tráfico de Pessoas sob a perspectiva de direitos humanos: prevenção, combate, proteção às vítimas e cooperação internacional. Ministério da Justiça, v. 1, 2013.

REICHEL, A.; ALBANESE, J. Handbook of Transnational Crime and Justice. Thousand Oaks: Sage Publications, 2014.

SOUSA, A. B. Investigação em Educação. Lisboa: Livros Horizontes, 2005.

TRANSPARENCY INTERNATIONAL. Corruption Perceptions Index, 2013. Disponível em: <www.transparency.org/cpi>. Acesso em: 20 ago. 2014

UNITED NATIONS. United Nations Office on Drugs and Crime, 2012. Homicide Statistics. Disponível em: <http://www.unodc.org/unodc/en/data-and-analysis/homicide.html>. Acesso em: 1 mar. 2014.

UNITED NATIONS. United Nations Office on Drugs and Crime. United Nations Convention Against Transnational Organized Crime and the Protocols Thereto, 2004. Disponível em: <http://www.unodc.org/documents/treaties/UNTOC/Publications/TOC\%20Convention/TOCe book-e.pdf>. Acesso em: 5 abr. 2014.

UNITED NATIONS. United Nations Office on Drugs and Crime. Human Trafficking Case Law Database. Disponível em: 〈http://www.unodc.org/cld/index.jspx>. Acesso em: 1 mai. 2014.

UNITED NATIONS, United Nations Office on Drugs and Crime. Estimating illicit financial flows resulting from drug trafficking and other transnational organized crimes, 2011. 
Disponível em: https://www.unodc.org/documents/data-andanalysis/Studies/Illicit_financial_flows_2011_web.pdf. Acesso em: 10 jun. 2014. UNITED STATES OF AMERICA. Department of State. International Narcotics Control Strategy Report, 2012. Disponível em: <http://www.state.gov/j/inl/rls/nrcrpt/2012/vol1/>. Acesso em: 26 fev. 2013.

UNITED STATES OF AMERICA, United States Department of State. Trafficking in Persons Report. 19 jun. 2013. Disponível em: <http://www.state.gov/j/tip/rls/tiprpt/index.htm>. Acesso em: 15 abr. 2014.

WALK FREE FOUNDATION. Global Slavery Index 2013. Disponível em: <http://www.globalslaveryindex.org/>. Acesso em: 2 mai. 2014.

WORLD ECONOMIC FORUM. The Global Competitiveness Report 2013-2014".

Disponível em: <http://www.weforum.org/reports/global-competitiveness-report-2013-2014>. Acesso em: 22 ago. 2014. 


\section{APÊNDICE 1}

Neste apêndice são apresentadas as informações coletadas na pesquisa empírica deste trabalho. Para a sistematização das informações de todos os países escolheu-se um modelo padrão em que se buscou a seguinte ordem de exposição: primeiramente a assinatura e ratificação, bem como suas eventuais ressalvas, ao Protocolo à Convenção de Palermo; em um segundo momento, uma breve apresentação da atual legislação nacional no que diz respeito ao tráfico internacional de pessoas, levando em consideração as peculiaridades e idiossincrasias de cada nação da amostra; e, por fim, a exibição dos dados dos indicadores de compliance encontrados junto ao Trafficking in Person Report, ao Global Slavery Index e também ao Human Trafficking Case Law Database. A apresentação das informações está segmentada por país, levando em conta a ordem alfabética, iniciando com o subitem A) Argentina e finaliza em M) Venezuela”.

\section{A) ARGENTINA}

A Argentina realizou a assinatura do Protocolo em 12 de dezembro de 2000, vindo a depositar sua ratificação dois anos após, em 19 de novembro de 2002. O país realizou a ratificação do texto completo e integral ao Protocolo não apresentando nenhuma declaração e/ou ressalva.

Atualmente o governo argentino possui uma norma específica que trata de tráfico de pessoas a Lei 26.842 - Prevencion y Sancion de la Trata de Personas Y Asistencia a sus victimas, ${ }^{38}$ foi sancionada e promulgada em dezembro de 2012. Na realidade, uma modificação da Lei 26.364, promulgada em 2008, referente ao tráfico de seres humanos. Contudo, a mais atual amplia a condenação dos crimes de tráfico, acelera o processo judicial, amplia os direitos das vítimas, transfere o crime para a esfera federal e endurece as penas dos culpados - sendo a pena máxima de quinze anos de prisão. Além desses pontos, a Lei 26.842 também prevê a criação de um Conselho Federal e um Comitê Executivo para a Luta contra o Tráfico e Exploração de Pessoas e a Proteção e Assistência as Vítimas. Convém ressaltar que

\footnotetext{
${ }^{38}$ Disponível em: http://www.infoleg.gov.ar/infolegInternet/anexos/205000-209999/206554/norma.htm
} 
em abril de 2013 foi criada a Procuraduría de trata y explotación de personas, ${ }^{39}$ com o objetivo de auxiliar os promotores de todo o país no processamento de casos de atos de sequestro, tráfico e crimes relacionados com o tráfico humano.

O Trafficking in Person Report elenca a Argentina como um país no Tier 2, cataloga o país como fonte, trânsito e destino de tráfico humano, com os objetivos principais de trabalho forçado e exploração sexual. De acordo com o relatório "The Government of Argentina does not fully comply with the minimum standards for the elimination of trafficking; however, it is making significant efforts to do so" (TRAFFICKING IN PERSON REPORT, 2013, p. 73).

De acordo com o Global Slavery Index o país argentino ocupa a $122^{\mathrm{a}}$ posição do ranking de um universo global de 162 países listados e apresenta um número estimado de escravos de 34.000 a 37.000 atualmente.

Para a análise da base de dados do Human Trafficking Case Law Database foi considerado como o ano base a data de 2008 , tendo em vista ter sido o ano em que houve a primeira mudança na legislação argentina depois da ratificação do Protocolo de Palermo.

\begin{tabular}{|c|c|}
\hline Human Trafficking Case Law Database & $\mathbf{N}^{\circ}$ TOTAL DE CASOS JULGADOS \\
\hline $\begin{array}{c}\text { BLOCO A } \\
\text { (antes de 2008) }\end{array}$ & 0 \\
\hline \multicolumn{2}{|c|}{2008 - Mudança no Código Penal } \\
\hline $\begin{array}{c}\text { BLOCO B } \\
\text { (depois de 2008) }\end{array}$ & 68 \\
\hline
\end{tabular}

\section{B) BELIZE}

Embora o Estado de Belize não seja signatário do Protocolo de Palermo, o país aderiu ao texto integral em 26 de setembro de $2003,{ }^{40}$ sem nenhuma ressalva. Essa nação também possui uma norma específica relacionada ao tráfico internacional de seres humanos. A Trafficking in Persons (Prohibition) Bill, de 2012, foi promulgada em fevereiro de 2013, ${ }^{41}$

\footnotetext{
${ }^{39}$ Mais informações em: http://www.mpf.gob.ar/protex/

${ }^{40} \mathrm{O}$ fato do país apenas aderir ao tratado possui a mesma força legal que a ratificação, com a diferença de que não houve a assinatura previamente. Fonte: http://www.unicef.org/crc/files/Definitions.pdf

${ }^{41}$ Disponível em: http://www.nationalassembly.gov.bz/index.php/hor-lowerhouse/bills-and-resolutionsbefore-the-house/doc_details/474-trafficking-in-persons-prohibition-bill-2012
} 
sendo esta uma lei que proíbe todas as formas de tráfico e prescreve punições de um a oito anos de prisão - dependendo do agravante podendo chegar até a 25 anos de cárcere. Essa norma é uma readequação de uma antiga lei, com o mesmo nome, de 2003, que previa penas de um a cinco anos de prisão. A nova lei elevou o delito de tráfico a partir de uma ofensa julgada em primeira instância a uma infração condenável julgada perante o Supremo Tribunal. O governo de Belize ainda possui outras iniciativas como a Intergovernmental agency task force on trafficking in persons - uma iniciativa reunindo treze agências nacionais e ONGs no país -, e também a adoção de um Plano Estratégico ${ }^{42}$ para o combate a esse crime.

O Trafficking in Person Report elenca Belize como um país no Tier 2, sendo, portanto, considerado como fonte, trânsito e destino de tráfico humano. Uma forma comum de tráfico em Belize ocorre tanto através do aliciamento de crianças por meio dos próprios pais - estes forçam a exploração sexual de seus filhos em troca de favores ou dinheiro -, quanto do turismo sexual infantil (TRAFFICKING IN PERSON REPORT, 2013, p. 94). Cabe frisar que na última edição do Global Slavery Index Belize não foi incluído na composição dos países listados.

Para a análise da base de dados do Human Trafficking Case Law Database, no caso de Belize foi considerado como o ano base a data de 2003, por ter sido o ano da primeira mudança na legislação local depois da adesão ao Protocolo de Palermo.

\begin{tabular}{|c|c|}
\hline $\begin{array}{c}\text { Belize } \\
\text { Human Trafficking Case Law Database }\end{array}$ & $\mathbf{N}^{\circ}$ TOTAL DE CASOS JULGADOS \\
\hline $\begin{array}{c}\text { BLOCO A } \\
\text { antes de 2003) }\end{array}$ & 0 \\
\hline \multicolumn{2}{|c|}{2003 - Mudança no Código Penal } \\
\hline $\begin{array}{c}\text { BLOCO B } \\
\text { (depois de 2003) }\end{array}$ & 3 \\
\hline
\end{tabular}

\section{C) BRASIL}

O Brasil realizou a assinatura do Protocolo de Palermo em 12 de dezembro de 2000, vindo a ratificá-lo, sem nenhuma ressalva, no início de 2004, mais precisamente em 29 de janeiro daquele ano.

\footnotetext{
${ }^{42}$ Mais informações em: http://www.ohchr.org/EN/NewsEvents/Pages/DisplayNews.aspx?NewsID=14135\&
} 
Apesar de a legislação brasileira estar voltada para a problemática do tráfico de pessoas, faz de maneira difusa. Primeiramente, o Decreto $\mathrm{n}^{\circ}$ 5.017, de março de 2004 promulga o Protocolo adicional à Convenção de Palermo no território brasileiro. Um ano após, em março de 2005, há, de fato, uma mudança concreta na legislação penal com a Lei $n^{\circ}$ $11.106^{43}$ que altera o Código Penal brasileiro, vigente desde 1940, no que se refere à alteração dos artigos 148, 215, 216, 226, 227, 231 e acrescenta o artigo 231. Essa lei endereçada ao tráfico de pessoas estabelece penas de três a doze anos, além da possibilidade do pagamento de multas.

Ainda sobre a mudança na legislação brasileira, mas não necessariamente no Código Penal, os esforços do governo do Brasil ainda contam com a Portaria $\mathrm{n}^{\circ} 2.167$, de dezembro de 2006 - instituindo a aplicação do Plano de Ação para a Luta contra o Tráfico de Pessoas entre os membros do Mercosul; o Decreto $\mathrm{n}^{\circ}$ 5.948, também de dezembro de 2006 aprovando a Política Nacional de Enfrentamento ao Tráfico de Pessoas; o Decreto $\mathrm{n}^{\mathrm{o}}$ 6.347, de janeiro de 2008 - aprovando o Plano Nacional de Enfrentamento ao Tráfico de Pessoas; a Portaria SNJ no 031, de agosto de 2009 - definindo as atribuições dos Núcleos de Enfrentamento ao Tráfico de Pessoas e dos Postos Avançados; e finalmente o Decreto $\mathrm{n}^{\circ}$ 7.901, de fevereiro de 2013 - aprovando o II Plano Nacional de Enfrentamento ao Tráfico de Pessoas. $^{44}$

Dentre os esforços nacionais, o governo brasileiro manteve de abril de 2012 a maio de 2014 uma Comissão de Inquérito Parlamentar exclusiva para discutir assuntos concernentes ao tráfico humano. Em 26 de março de 2014 foi aprovado pelo plenário do Senado Federal um projeto de lei (PLS 479/2012) que visa modificar a atual legislação na matéria. ${ }^{45} \mathrm{O}$ projeto, que ainda necessita da aprovação da Câmara dos Deputados, inclui elementos de proteção à vítima, ampliação da tipificação criminal, engloba o trabalho escravo e a remoção de órgãos humanos, além de endurecer a legislação para os agentes criminosos. A proposição é por um tipo penal fechado para o tráfico humano, com a manutenção da pena máxima atual.

\footnotetext{
${ }^{43}$ Disponível em: http://www.planalto.gov.br/ccivil_03/_ato2004-2006/2005/lei/111106.htm

${ }^{44}$ Para mais informações acerca das portarias e decretos, disponível em: http://portal.mj.gov.br/data/Pages/MJ16B51547PTBRNN.htm

45 Mais informações em: http://www12.senado.gov.br/noticias/materias/2014/03/26/aprovado-projetoque-reforca-o-combate-ao-trafico-de-pessoas.
} 
De acordo com a última edição do Trafficking in Person Report, o Brasil é um grande país de destino, trânsito e fonte de tráfico humano, com destaque para o alto número de prostituição infantil que ocorre, principalmente, no nordeste do país e, por isso, está catalogado no Tier 2. Além de abordar a legislação difusa, o relatório menciona os esforços empreendidos pelo governo brasileiro no sentido de julgar culpados e a cooperação simultânea de dezesseis gabinetes antitráficos, quando se refere ao Plano Nacional. O Brasil ocupa a posição de número 94 no Global Slavery Index, possuindo uma população estimada de 200.000 a 220.000 escravos em seu território nacional.

Como anteriormente colocado, a mudança no Código Penal no Brasil foi em 2005, por isso servirá de ano divisor ao se observar o banco de dados do UNODC.

\begin{tabular}{|c|c|}
\hline $\begin{array}{c}\text { Brasil } \\
\text { Human Trafficking Case Law Database }\end{array}$ & $\mathbf{N}^{\circ}$ TOTAL DE CASOS JULGADOS \\
\hline $\begin{array}{c}\text { BLOCO A } \\
\text { antes de 2005) }\end{array}$ & 7 \\
\hline \multicolumn{2}{|c|}{2005 - Mudança no Código Penal } \\
\hline $\begin{array}{c}\text { BLOCO B } \\
\text { (depois de 2005) }\end{array}$ & 64 \\
\hline
\end{tabular}

\section{D) COLÔMBIA}

A Colômbia assinou o Protocolo à Convenção de Palermo logo que esta foi exposta pela ONU em dezembro de 2000. Porém, esse país só veio ratificá-la em 4 de agosto de 2004, apresentando uma reserva ${ }^{46}$ com relação ao parágrafo 2 do Protocolo. A Lei 800, de 2003, ${ }^{47}$ foi a norma que promulgou a sanção da validade da Convenção e do Protocolo de Palermo em território nacional colombiano. Ao passo que a norma que transformou a legislação e o código penal da Colômbia foi a Lei $985^{48}$, de 2005 , vindo a criar a atual penalização para o crime de 13 a 23 anos de prisão, mais a aplicação de multas -, e também a criação da Estrategia Nacional Contra la Trata de Personas, do Sistema Nacional de Información sobre Trata de

\footnotetext{
$46 \quad$ Ver: $\quad$ https://treaties.un.org/Pages/ViewDetails.aspx?src=TREATY\&mtdsg_no=XVIII-12a\&chapter=18\&lang=en\#EndDec

${ }^{47}$ Ver:

http://www.cicad.oas.org/Fortalecimiento_Institucional/ESP/Leyes\%20para\%20e1\%202007/COLEY_800_DE_2 003.pdf

${ }^{48}$ Para mais detalhes: http://www.hsph.harvard.edu/population/trafficking/colombia.traf.05.pdf
} 
personas, e as funções do Comité Interinstitucional para la lucha contra la Trata de Personas.

Para o Trafficking in Person Report o governo colombiano tem se destacado. Apesar de ser um país fonte de abuso sexual de crianças e mulheres, além de fonte, trânsito e destino para homens, mulheres e crianças no que se refere ao trabalho forçado, a Colômbia tem apresentado um compliance completo. Em face disso, o país se configura no Tier 1. Contudo, o relatório faz a ressalva de que alguns problemas estruturais no governo são falhos e deixam a abordagem do enfrentamento menos efetiva (TRAFFICKING IN PERSON REPORT, 2013, p. 132).

Em se tratando do Global Slavery Index, o país colombiano está na $73^{a}$ posição do ranking, contando com uma população estimada de 120.000 a 140.000 escravos em seu território. $\mathrm{Na}$ análise do banco de dados disponível pelo Human Trafficking Case Law Database, o ano de 2005 foi considerado como o ano divisor:

\begin{tabular}{|c|c|}
\hline Human Trafficking Case Law Database & N$^{\circ}$ TOTAL DE CASOS JULGADOS \\
\hline $\begin{array}{c}\text { CLOCO A } \\
\text { (antes de 2005) }\end{array}$ & 4 \\
\hline \multicolumn{2}{|c|}{2005 - Mudança no Código Penal } \\
\hline $\begin{array}{c}\text { BLOCO B } \\
\text { (depois de 2005) }\end{array}$ & 14 \\
\hline
\end{tabular}

E) COSTA RICA

O governo costa-riquenho assinou o Protocolo de Palermo em março de 2001 e efetivou sua ratificação de fato dois anos após, em 9 de setembro de 2003. No momento de ratificação não houve nenhuma ressalva, sendo o texto aprovado em sua integralidade. A Costa Rica vem a possuir sua primeira mudança na legislação nacional, com relação ao tráfico de pessoas, pela sanção da Lei $n^{\circ} 8.315,{ }^{49}$ que ocorreu em setembro de 2002. A sanção dessa norma teve a intenção de promulgar o tratado internacional em ambiente doméstico costariquenho. Após esse marco, já no ano de 2005 é criado o Decreto Executivo no 34.199 que, dentre outras atribuições, cria a Coalición Nacional Contra el Tráfico Ilícito de Migrantes y

\footnotetext{
${ }^{49}$ Para mais detalhes: http://costa-rica.justia.com/nacionales/leyes/ley-8315/gdoc/
} 
Trata de Personas, sendo esta uma entidade constituída de diferentes instituições e organizações para o combate ao tráfico de pessoas e a atenção às vítimas. Finalmente em 2012, é aprovada a Lei $n^{\circ}$ 9.095, Ley Contra la Trata de Personas, ${ }^{50}$ específica para o tráfico humano na Costa Rica. De acordo com essa norma, ficam estabelecidas penas de 4 a 20 anos de prisão para os culpados.

O relatório do Departamento de Estado norte-americano enquadra a nação de Costa Rica na posição de Tier 2, sendo que, nos últimos anos, tem se destacado o tráfico de crianças e utilização destas em atividades ilícitas de tráfico de drogas. O relatório critica que a nova legislação possui diversos pontos falhos, sendo muito ampla em alguns pontos e muito estreita em outros (TRAFFICKING IN PERSON REPORT, 2013, p. 140).

Com relação ao índice global de escravidão, a Costa Rica está em uma posição bastante favorecida, configurando-se na $146^{\mathrm{a}}$ posição do ranking. De acordo com esse mesmo Global Slavery Index, o número estimado de escravos fica em torno de 650 a 710 de uma população total de cerca de 5 milhões de habitantes. Considerado pelo Human Trafficking Case Law Database o ano base 2012.

\begin{tabular}{|c|c|}
\hline Human Trafficking Case Law Database & $\mathbf{N}^{\circ}$ TOTAL DE CASOS JULGADOS \\
\hline $\begin{array}{c}\text { BLOCO A } \\
\text { antes de 2012) }\end{array}$ & 2 \\
\hline \multicolumn{2}{|c|}{2012 - Mudança no Código Penal } \\
\hline $\begin{array}{c}\text { BLOCO B } \\
\text { (depois de 2012) }\end{array}$ & 0 \\
\hline
\end{tabular}

\section{F) CHILE}

O Chile realizou sua assinatura ao Protocolo de Palermo em agosto de 2002 e o ratificou dois anos depois, em novembro de 2004, sem nenhuma ressalva ao texto original. A internalização do tratado internacional de Palermo se deu no mesmo ano de 2004. Em dezembro daquele ano foi promulgado o Decreto $\mathrm{n}^{\circ} 342$, o qual tornava a Convenção de

\footnotetext{
${ }^{50}$ Para mais detalhes:

http://www.migracion.go.cr/institucion/Trata/Ley\%20Trata\%20de\%20Personas\%20(difusion\%20digital).pdf
} 
Palermo e todos os seus Protocolos vigentes no território chileno. ${ }^{51}$ Após esse decreto, no ano de 2005, começou a tramitar um projeto de lei para a mudança no código penal, porém, apenas em abril de 2011 o projeto foi aprovado e a Lei $n^{\circ} 20.507$ entrou em vigor no Chile. ${ }^{52}$ Essa norma estabelece penas de 5 a 15 anos e aplicação de multas. Para conseguir cumprir os dispositivos da mudança no código penal, também foi criado, em 2013, o Plan Nacional contra la Trata de Personas en Chile.

No que diz respeito ao relatório publicado pelo Departamento de Estado dos Estados Unidos, o Chile está no Tier 2. Além de ser, como a maioria dos latino-americanos, um país fonte, trânsito e de destino do tráfico humano, o destaque é em relação às vítimas traficadas para trabalho forçado em minas, na agricultura e serviços domésticos.

Com uma população escrava estimada entre 36.000 a 40.000, o Chile se apresenta na posição 89 do ranking do Global Slavery Index. Analisando o Human trafficking Case Law Database e tomando o ano divisor como o de 2011:

\begin{tabular}{|c|c|}
\hline $\begin{array}{c}\text { Chile } \\
\text { Human Trafficking Case Law Database }\end{array}$ & $\mathbf{N}^{\circ}$ TOTAL DE CASOS JULGADOS \\
\hline $\begin{array}{c}\text { BLOCO A } \\
\text { (antes de 2011) }\end{array}$ & 3 \\
\hline \multicolumn{2}{|c|}{2011 - Mudança no Código Penal } \\
\hline $\begin{array}{c}\text { BLOCO B } \\
\text { (depois de 2011) }\end{array}$ & 1 \\
\hline
\end{tabular}

\section{G) EL SALVADOR}

O governo de El Salvador realizou a assinatura do Protocolo em agosto de 2002 e o ratificou em 18 de março de 2004. Contudo, no momento de sua ratificação apresentou reservas em relação ao artigo 15 , parágrafo 2 , e não reconheceu a jurisdição compulsória da Corte Internacional de Justiça. O caso de El Salvador, com relação a sua Constituição Federal, é curioso, tendo em vista que, nesse país, a mudança em sua legislação doméstica se deu entre a assinatura do tratado e a ratificação deste. Isto porque em El Salvador o crime de tráfico de pessoas foi tipificado em janeiro de 2004, pelo Decreto Legislativo $\mathrm{n}^{\mathrm{o}} 210$ da reforma do

\footnotetext{
51 Ver:

http://www.oas.org/dil/esp/Convencion_Internacional_contra_Delincuencia_Organizada_Transnacional_y_sus_ Protocolos.pdf

${ }^{52}$ Mais informações em: http://www.leychile.cl/Navegar?idNorma=1024319
} 
Código Penal. Com essa mudança foi introduzido o artigo 367-B, endereçado especificamente ao tráfico internacional de pessoas, ${ }^{53}$ estabelecendo a pena de 4 a 8 anos de prisão. Para cumprir com o estabelecido no artigo 367-B, o governo el salvadorenho criou o Consejo Nacional contra la Trata de Personas, pelo Decreto Executivo $\mathrm{n}^{\circ}$ 90, em agosto de 2011. Convém ressaltar que El Salvador também possui uma Politica nacional contra la Trata de Personas criado em fevereiro de 2013 pelo Poder Executivo. Nos últimos anos o governo federal local está trabalhando em um anteprojeto de lei - a Ley Especial contra la Trata de Personas - na busca da aprovação de uma norma específica para enquadrar o tráfico humano no país, ${ }^{54}$ além do endurecimento das penas.

De acordo com o Trafficking in Person Report, as principais formas de exploração no país ocorre pela exploração sexual de mulheres e meninas, além do trabalho forçado na agricultura e servidão doméstica de adultos e crianças. $\mathrm{O}$ fato de gangues locais utilizarem crianças, através da força e coerção, em atividades como o tráfico de drogas ajudam a posicionar o país no Tier 2. A corrupção, principalmente, junto ao Poder Judiciário é um dos principais pontos que enfraquece a busca de um compliance satisfatório.

No ranking do Global Slavery Index El Salvador está na $95^{\mathrm{a}}$ posição, com uma população estimada de 10.000 a 11.000 escravos atualmente. Analisando o banco de dados do braço institucional da ONU, e tomando como base o ano de 2004.

\begin{tabular}{|c|c|}
\hline Human Trafficking Case Law Database & N $^{\circ}$ TOTAL DE CASOS JULGADOS \\
\hline $\begin{array}{c}\text { BLOCO A } \\
\text { (antes de 2004) }\end{array}$ & 0 \\
\hline \multicolumn{2}{|c|}{2004 - Mudança no Código Penal } \\
\hline $\begin{array}{c}\text { BLOCO B } \\
\text { (depois de 2004) }\end{array}$ & 6 \\
\hline
\end{tabular}

\footnotetext{
53 Mais informações em: http://www.oas.org/dil/esp/Articulo_367_del_Codigo_Penal.pdf e também http://www.seguridad.gob.sv/index.php?option=com_content\&view=category\&id=78\&Itemid=113

54 Anteprojeto em tramitação na Assembleia Legislativa, mais informações em: http://www.asamblea.gob.sv/noticias/construyendo-democracia/archivo-de-noticias/gpm-recibe-ley-especialcontra-la-trata-de-personas
} 


\section{H) HONDURAS}

Honduras, assim como Belize, não realizou a assinatura do Protocolo de Palermo. No entanto, o país aderiu a este em 1 de abril de 2008 e, no momento de adesão, não houve nenhuma ressalva. No país hondurenho no que se trata de modificação da legislação penal, a primeira iniciativa foi através do Decreto $\mathrm{n}^{\circ} 234-2005$ de agosto de 2005, com a reforma do Código Penal, intitulado De los delitos contra la libertad sexual y la honestidad, no artigo 149 do código. ${ }^{55}$ Essa norma impunha penas de 8 a 13 anos de prisão, mais a possibilidade de multas. Contudo, depois da adesão ao Protocolo de Palermo, houve a criação de uma lei única de combate ao tráfico internacional de seres humanos.

Em maio de 2012, foi estabelecida através do Decreto 59/2012 a Ley Contra la Trata de Personas, que endureceu ainda mais esse crime, estabelecendo penas de 10 a 15 anos de prisão e multas. ${ }^{56} \mathrm{O}$ governo também estabeleceu, permanentemente, uma Comisión Interinstitucional contra la Explotación Sexual Comercial y Trata de Personas de Honduras. Acrescente-se que, em junho de 2014, o presidente de Honduras lançou a Campaña Nacional contra la Trata de Personas.

Quanto ao relatório publicado pelo Departamento de Estado norte-americano, Honduras está enquadrado no Tier 2 - Watching List, pois é considerado como fonte e de trânsito para homens, mulheres e crianças sujeitos à exploração sexual e a trabalhos forçados, principalmente em países de destino como México, Guatemala, El Salvador e Estados Unidos. O ponto de destaque negativo apontado é para as famílias rurais que "emprestam" seus filhos para trabalhos forçados nas cidades, incluindo exploração sexual e mendicância.

Com uma população escrava estimada entre 7.100 a 7.900, Honduras se apresenta em na posição 110 do Global Slavery Index. Tendo em vista que na base de dados do Human Trafficking Case Law Database o país hondurenho não possui nenhum caso registrado, isso inviabilizou qualquer análise comparativa deste país.

\footnotetext{
${ }_{55}^{55}$ Mais informações em: http://www.acnur.org/biblioteca/pdf/4874.pdf?view=1

${ }^{56}$ Mais informações em: http://chfhonduras.org/wp-

content/uploads/downloads/2013/08/Ley\%20Trata\%20de\%20Personas\%20Honduras\%202013.pdf
} 


\section{I) MÉXICO}

O Estado mexicano veio a assinar o Protocolo de Palermo em dezembro de 2000, logo junto ao seu lançamento. Já sua ratificação, feita sem nenhuma ressalva ao texto original, ocorreu em 4 de março de 2003.

O sistema de governo mexicano é federativo, sendo delegado a cada um de seus 32 estados o poder de legislar sobre determinadas matérias. Em relação ao tráfico internacional de pessoas, no nível federal existe a promulgação de leis que servem como norteadoras aos estados, os quais, por sua vez, desenvolvem leis próprias nessa matéria específica. A primeira modificação na legislação federal mexicana ocorreu em 27 de novembro de 2007, com a promulgação da Ley para prevenir y sancionar la trata de personas. ${ }^{57}$ Essa lei, além de tipificar o tráfico, estabelecia penas de 6 a 18 anos de prisão para os culpados.

Em 2008, foi estabelecida a Fiscalia Especial para llos Delitos de Violencia contra las Mujeres y la Trata de Personas e, em 2009, foi estabelecido, em todo o território nacional, o Programa Nacional para Prevenir y Sancionar la Trata de Personas, um plano norteador para todos os estados da federação mexicana. Ainda no que se trata de modificação na legislação, recentemente - em junho de 2012, com a última modificação de março de 2014 foi estabelecida uma nova lei em âmbito nacional no México: a Ley general para prevenir, sancionar y erradicar los delitos en materia de trata de personas y para la protección y asistencia a las víctimas de estos delitos. ${ }^{58}$ Essa nova norma modificou e endureceu ainda mais as vigentes punições para o crime de tráfico humano, sendo que as penas passaram para os patamares de 5 a 30 anos de aprisionamento.

Os grupos considerados os mais suscetíveis ao tráfico humano no México incluem, além de mulheres e crianças, também indígenas, pessoas com deficiência física e gays, lésbicas, bissexuais e transgêneros jovens, bem como imigrantes ilegais. Para o Trafficking in Person Report a realidade mexicana é de que o governo continua a aumentar os esforços para a implantação de leis, particularmente no nível estatal, mas sem a devida coordenação em

\footnotetext{
${ }^{57}$ Mais informações em: http://www.hsph.harvard.edu/population/trafficking/mexico.trafficking.07.pdf

${ }^{58}$ Mais informações em: http://www.diputados.gob.mx/LeyesBiblio/pdf/LGPSEDMTP.pdf
} 
todos os estados e, por isso, encontra-se enquadrado no Tier 2 (TRAFFICKING IN PERSON REPORT, 2013, p. 261).

O México ocupa a posição de número 107 no Global Slavery Index, possuindo uma população estimada de 98.000 a 110.000 escravos em seu território nacional. Tendo em vista que na base de dados do Human Trafficking Case Law Database o México não possui nenhum caso registrado, não foi possível realizar uma análise comparativa deste país. ${ }^{59}$

\section{J) NICARÁGUA}

Nicarágua não realizou a assinatura do Protocolo de Palermo, embora tenha aderido a ao texto integral em 12 de outubro de 2004, sem nenhuma ressalva. O país centro-americano não apresenta uma lei específica destinada ao tráfico internacional de pessoas. No entanto, após a adesão ao tratado internacional houve mudanças no código penal para que o crime de tráfico humano fosse tipificado. Através da Lei ${ }^{\circ} 641$, de novembro de $2007,{ }^{60}$ houve a inclusão de 3 artigos - artigos 182; 183e 315 - ao código penal que permitisse as autoridades nacionais julgarem criminosos nessa matéria. A penalização era de 7 a 12 anos, porém em agosto de 2012 houve uma reforma no código penal aumentando assim as penas para 10 a 14 anos de prisão. Atualmente as autoridades nicaraguenses estão trabalhando para que haja uma normativa especial e específica na matéria do tráfico, assim, em março de 2014, um anteprojeto de lei - o Anteproyecto de Ley Especial e Integral Contra la Trata de Personas foi apresentado na primeira secretaria da Assembleia Nacional local. ${ }^{61}$

$\mathrm{Na}$ análise do Departamento de Estado dos Estados Unidos o governo de Nicarágua apesenta um compliance total na busca da eliminação do tráfico humano. Apesar de cidades como Managua, Granada e Esteli ainda serem rotas de destino de turismo sexual, por meio da coerção e tráfico de crianças nessas regiões, Nicaragua está no Tier 1 do Trafficking in Person Report.

\footnotetext{
${ }^{59}$ Importante ressaltar que a nulidade do registro de caso não equivale a nenhum caso julgado e processado no México. Porém, tendo em vista a uniformidade do processo metodológico e a análise desta base de dados não permite levar em consideração outras fontes.

${ }^{60}$ Mais informações em: http://www.protectionproject.org/wp-content/uploads/2010/09/NICARAGUASPANISH.pdf

${ }^{61}$ Mais informações em: http://www.asamblea.gob.ni/194416/anteproyecto-de-ley-contra-la-trata-serapresentado-ante-la-primera-secretaria/
} 
Com uma população escrava estimada entre 5.500 a 6.100, o Chile se apresenta na posição 108 do ranking do Global Slavery Index. Como já colocado, a mudança no Código Penal na Nicarágua foi em 2007, por isso, será tomado como ano como divisor, ao se analisar o banco de dados do UNODC.

\begin{tabular}{|c|c|}
\hline $\begin{array}{c}\text { Nicarágua } \\
\text { Human Trafficking Case Law Database }\end{array}$ & $\mathbf{N}^{\circ}$ TOTAL DE CASOS JULGADOS \\
\hline $\begin{array}{c}\text { BLOCO A } \\
\text { antes de 2007) }\end{array}$ & 0 \\
\hline \multicolumn{2}{|c|}{2007 - Mudança no Código Penal } \\
\hline $\begin{array}{c}\text { BLOCO B } \\
\text { (depois de 2007) }\end{array}$ & 6 \\
\hline
\end{tabular}

\section{K) PERU}

A nação peruana apresentou sua assinatura ao Protocolo Relativo à Prevenção, Repressão e Punição do Tráfico de Pessoas, em Especial Mulheres e Crianças da Convenção de Palermo em dezembro de 2000 e o ratificou na íntegra em 22 de janeiro de 2002.

Em relação aos instrumentos legais, o país peruano possui normas específicas para combater o tráfico humano. Em janeiro de 2007 foi promulgada a Lei $n^{\circ} 28.950$ que, ao incluir os artigos 153 e 153-A, colocava em vigor a Ley contra la trata de personas y el tráfico ilícito de migrantes, impondo penas que vão desde 8 até o máximo de 25 anos de aprisionamento. $^{62}$ Outras normas nacionais relacionadas ao tráfico de pessoas também entraram em vigor no Peru: em 2004, o Decreto Supremo 002-2004-IN, instaurando o Grupo de trabalho multissetorial permanente contra o tráfico de pessoas; e em 2006, a Resolução Ministerial 2570-2006-IN/0105, institucionalizando o Sistema de Registro y Estadística del delito de Trata de personas y Afines. ${ }^{63}$

O Peru, assim como muitos dos países latino-americanos, é considerado um país de fonte, trânsito e destino do tráfico humano, sendo os principais objetivos dos criminosos a exploração de homens, mulheres e crianças por meio do trabalho forçado em minas de ouro e serviços como mendicância, e trabalhos domésticos. O relatório do Trafficking in Person também aponta que há contínuas denúncias de recrutamento pelo grupo terrorista Sendero

\footnotetext{
${ }^{62}$ Mais informações em: http://www.mintra.gob.pe/migrante/pdf/Ley_28950_Trata.pdf

${ }^{63}$ Mais informações em (página 75): http://www.trabajo.gob.pe/migrante/pdf/trata_personas_peru.pdf
} 
Luminoso, de crianças e adultos - dentro e fora do Peru - para sua utilização como combatentes e no tráfico ilegal de drogas. Dessa maneira, o país enquadra-se no Tier 2.

Ao ser estimada uma população escrava na ordem de grandeza de 78.000 a 86.000 de seres humanos, o Peru está em uma posição de destaque negativo diante seus vizinhos sulamericano, por se posicionar na $65^{\mathrm{a}}$ posição do ranking do Global Slavery Index.

Como a mudança no Código Penal no Peru se deu no ano de 2007, esse ano é tido como divisor, ao se analisar o banco de dados do Human Trafficking Case Law Database.

\begin{tabular}{|c|c|}
\hline $\begin{array}{c}\text { Peru } \\
\text { Human Trafficking Case Law Database }\end{array}$ & $\mathbf{N}^{\circ}$ TOTAL DE CASOS JULGADOS \\
\hline $\begin{array}{c}\text { BLOCO A } \\
\text { (antes de 2007) }\end{array}$ & 1 \\
\hline \multicolumn{2}{|c|}{2007 - Mudança no Código Penal } \\
\hline $\begin{array}{c}\text { BLOCO B } \\
\text { depois de 2007) }\end{array}$ & 6 \\
\hline
\end{tabular}

\section{L) URUGUAI}

O Uruguai realizou sua assinatura ao Protocolo de Palermo em dezembro de 2000, porém a sua ratificação só veio após 5 anos, visto que a data oficial de ratificação se deu em 4 de março de 2005. O governo uruguaio realizou a ratificação sem nenhuma ressalva.

O país uruguaio possui uma única legislação que trata da matéria específica de tráfico internacional de seres humanos. A Lei $n^{\mathrm{o}} 18.250,{ }^{64}$ promulgada em janeiro de 2008 , adicionou ao Código Penal uruguaio, no capítulo XV, os artigos 78, 79, 80 e 81, sendo que esta norma específica dá o embasamento legal para o julgamento e a penalização - de 4 a 16 anos de prisão - de criminosos culpados por tráfico humano. O país uruguaio não possui, até o presente momento, nenhuma outra norma específica ou mesmo um Plano Nacional para endereçar a questão do tráfico.

O Trafficking in Person Report elenca o Uruguai como um país no Tier 2 - Watching List, considerando-o como fonte de mulheres e crianças sujeitas à exploração sexual. Essas vítimas são forçadas à prostituição, principalmente, na Espanha, Itália e Argentina. Segundo o referido relatório, o governo Uruguai não conseguiu condenar nenhum criminoso sob a

\footnotetext{
${ }^{64}$ Mais informações em: http://www.parlamento.gub.uy/leyes/AccesoTextoLey.asp?Ley=18250\&Anchor
} 
legislação específica de tráfico de pessoas presente no Código Penal desde 2008 (TRAFFICKING IN PERSON REPORT, 2013, p. 387).

De acordo com o Global Slavery Index, o Uruguai ocupa a $72^{a}$ posição do ranking no total de 162 países listados e possui um número estimado de escravos de 9.500 a 10.000 atualmente.

Tendo em vista que na base de dados do Human Trafficking Case Law Database o Uruguai não possui nenhum caso registrado, o que impossibilitou a análise comparativa. ${ }^{65}$

\section{M) VENEZUELA}

A Venezuela apresentou sua assinatura ao Protocolo de Palermo em dezembro de 2000, sua ratificação se deu 2 anos após, em maio de 2002 sem nenhuma ressalva ao texto original. O Estado venezuelano não possui uma norma especial que trate do tráfico humano, porém após a ratificação do Protocolo de Palermo houve mudanças na legislação local. Em setembro de 2005 foi criada a Ley orgánica contra la delincuencia organizada ${ }^{66}$ que, ao abarcar todo o grupo de atividades ilícitas do crime organizado, contemplava a questão do tráfico de pessoas, imputando penas de 10 a 20 anos de prisão. Essa norma foi reformulada em abril de 2012, passando a se chamar Ley orgánica contra la delincuanecia organizada y financiamiento al terrorismo $^{67}$ que, por intermédio de seu artigo 41, abarcou o tráfico de seres humanos, com o endurecimento de penas de 20 a 30 anos. Ainda se tratando de criação de legislação voltada para o enfrentamento ao tráfico humano, a Venezuela também promulgou, em abril de 2007, a Ley orgánica sobre el derecho de las mujeres a una vida libre de violencia ${ }^{68}$ que, através de seu artigo 56, faz menção ao tráfico de mulheres, meninas e adolescentes.

O país está enquadrado, segundo o Trafficking in Person Report, no Tier 2 - Watching List, tendo em vista que o governo do país tem demonstrado empenho para cumprir com o compliance esperado. Todavia, questões graves como o transporte de mulheres, via pequenos

\footnotetext{
${ }^{65} \mathrm{~A}$ nulidade do registro de caso não equivale a nenhum caso julgado e processado no território de Honduras.

${ }^{66}$ Mais informações em:

http://www.acnur.org/t3/fileadmin/scripts/doc.php?file=t3/fileadmin/Documentos/BDL/2008/6603

${ }^{67}$ Mais informações em:

http://www.cpzulia.org/ARCHIVOS/Ley_Organica_contra_Delincuencia_Organizada_y_Financiamiento_al_Te rrorismo_30_04_12.pdf

${ }^{68}$ Mais informações em: http://www.protectionproject.org/wp-content/uploads/2010/09/VENEZUALA-

SPANISH.pdf
} 
barcos, das áreas costeiras do país até ilhas caribenhas - particularmente Aruba, Curacao e Trinidad e Tobago - para a prostituição forçada nesses países de destino, acabam por minar parte dos esforços venezuelanos.

No ranking do Global Slavery Index a Venezuela está na $75^{\text {a }}$ posição, com uma população estimada de 76.000 a 84.000 escravos na atualidade. Ao se analisar o Human trafficking Case Law Database e tomando-se o ano divisor como o de 2005:

\begin{tabular}{|c|c|}
\hline Human Trafficking Case Law Database & $\mathbf{N}^{\circ}$ TOTAL DE CASOS JULGADOS \\
\hline $\begin{array}{c}\text { BLOCO A } \\
\text { antes de 2005) }\end{array}$ & 0 \\
\hline \multicolumn{2}{|c|}{2005 - Mudança no Código Penal } \\
\hline $\begin{array}{c}\text { BLOCO B } \\
\text { (depois de 2005) }\end{array}$ & 1 \\
\hline
\end{tabular}




\section{APÊNDICE 2}

Tabela 11 do Anexo II - Indicador de Compliance com Normas em Tráfico de Pessoas

\begin{tabular}{|c|c|c|c|c|c|c|c|c|c|c|c|c|c|c|c|c|c|}
\hline$I C C J$ & & $\begin{array}{l}\text { Tempo para } \\
\text { Ratificação }\end{array}$ & $\begin{array}{l}\text { Índice tempo de } \\
\text { ratificação (a) }\end{array}$ & $\begin{array}{c}\text { Tempo para } \\
\text { produção } \\
\text { norma }\end{array}$ & $\begin{array}{l}\text { Índice tempo } \\
\text { de produção } \\
\text { (a) }\end{array}$ & $\begin{array}{c}\text { Pena máxima } \\
\text { para Tráfico } \\
\text { de Pessoas }\end{array}$ & $\begin{array}{c}\text { Índice } \\
\text { Penal (b) }\end{array}$ & $\begin{array}{l}\text { Trafficking } \\
\text { in Person } \\
\text { Report (c) }\end{array}$ & $\begin{array}{c}\text { Indice } \\
\text { Trafficking } \\
\text { in Person } \\
\text { Report (b) }\end{array}$ & $\begin{array}{c}\text { Global } \\
\text { Slavery } \\
\text { Index }\end{array}$ & $\begin{array}{c}\text { Indice } \\
\text { Global } \\
\text { Slavery } \\
\text { Index (b) }\end{array}$ & $\begin{array}{c}\text { Human Traf. Case } \\
\text { Law Database - } \\
2014\end{array}$ & $\begin{array}{l}\text { População } 2014 \\
\text { (d) }\end{array}$ & $\begin{array}{c}\text { Taxa de } \\
\text { Julgamento (e) }\end{array}$ & $\begin{array}{c}\text { Índice de } \\
\text { Casos } \\
\text { Julgados (b) }\end{array}$ & $\begin{array}{c}\text { Mobilizacão } \\
\text { Institucional } \\
\text { para o } \\
\text { Enfrentamento } \\
\text { ao Tráfico de } \\
\text { Pessoas (f) }\end{array}$ & $\begin{array}{c}\frac{\text { Indicador de }}{\text { Compliance com }} \\
\frac{\text { normas em }}{\text { Tráfico de }} \\
\frac{\text { Pessoas }}{\text { Pesos }}\end{array}$ \\
\hline \multirow{5}{*}{1} & Argentina & 2 & 1 & 6 & 0,3 & 15 & 0,75 & 3 & 1,0 & 122 & 0,8 & 68 & 43.024 .374 & 0,16 & 1,0 & 1 & 5,9 \\
\hline & Chile & 4 & 0,5 & 7 & 0,3 & 15 & 0,75 & 3 & 1,0 & 89 & 0,6 & 1 & 17.363 .894 & 0,01 & 0,0 & 1 & 4,2 \\
\hline & Costa Rica & 3 & 0,7 & 2 & 1,0 & 20 & 1 & 3 & 1,0 & 146 & 1,0 & 0 & 4.755 .234 & - & . & 1 & 5,7 \\
\hline & Uruguai & 5 & 0,4 & 3 & 0,7 & 16 & 0,8 & 2 & 0,7 & 72 & 0,5 & 0 & 3.332 .972 & - & - & 0 & 3,0 \\
\hline & Melhor resultado & 2 & & 2 & & 20 & & 3 & & 146 & & & & 0,16 & & & \\
\hline \multirow{7}{*}{2} & Belize & 3 & 0,7 & 0 & 1,0 & 25 & 0,83 & 3 & 0,8 & - & - & 3 & 340.844 & 0,88 & 1,0 & 1 & 5,3 \\
\hline & Brasil & 4 & 0,5 & 1 & 0,0 & 12 & 0,40 & 3 & 0,8 & 94 & 0,9 & 64 & 202.656 .788 & 0,03 & 0,0 & 1 & 3,5 \\
\hline & E1 Salvador & 4 & 0,5 & 0 & 1,0 & 8 & 0,27 & 3 & 0,8 & 95 & 0,9 & 6 & 6.125 .512 & 0,10 & 0,1 & 1 & 4,5 \\
\hline & Honduras & 8 & 0,3 & -3 & 0,0 & 15 & 0,50 & 2 & 0,5 & 110 & 1,0 & 0 & 8.598 .561 & - & - & 1 & 3,2 \\
\hline & Nicarágua & 4 & 0,5 & 3 & 0,0 & 14 & 0,47 & 4 & 1,0 & 108 & 1,0 & 6 & 5.848 .641 & 0,10 & 0,1 & 0 & 3,1 \\
\hline & Venezvela & 2 & 1,0 & 3 & 0,0 & 30 & 1,00 & 2 & 0,5 & 75 & 0,7 & 1 & 28.868 .486 & 0,00 & 0,0 & 0 & 3,2 \\
\hline & Melhor resultado & 2 & & 0 & & 30 & & 4 & & 110 & & & 202.656 .788 & 0,88 & & & \\
\hline \multirow{4}{*}{3} & Colômbia & 4 & 0,5 & 1 & 1,0 & 23 & 0,77 & 4 & 1,0 & 73 & 0,7 & 14 & 46.245 .297 & 0,03 & 1,0 & 1 & 5,9 \\
\hline & México & 3 & 0,7 & 4 & 0,3 & 30 & 1,00 & 3 & 0,8 & 107 & 1,0 & 0 & 120.286 .655 & 0 & - & 1 & 4,7 \\
\hline & Perv & 2 & 1,0 & 5 & 0,2 & 25 & 0,83 & 3 & 0,8 & 65 & 0,6 & 6 & 30.147 .935 & 0,02 & 0,7 & 0 & 4,0 \\
\hline & Melhor resultado & 2 & & 1 & & 30 & & 4 & & 107 & & & 120.286 .655 & 0,03 & & & \\
\hline \multicolumn{18}{|c|}{ Corresponde zo melhor resultado do ICCJ analisado dividido pelo valor em análise } \\
\hline \multirow{2}{*}{\multicolumn{18}{|c|}{$\begin{array}{l}\text { b) Corresponde ao valor em análise dividido pelo melhor resultado do ICCJ analisado } \\
\text { c) Potuąão segue a seguinte lógica: Tier } 1=4 \text { pontos; Tier } 2=3 \text { pontos; Tier } 2 \text { Watching list }=2 \text { pontos; Tier } 3=1 \text { ponto }\end{array}$}} \\
\hline & & & & & & & er $3=1$ pont & & & & & & & & & & \\
\hline \multicolumn{18}{|c|}{ d) Fonte: The World Factbook - CIA } \\
\hline \multicolumn{18}{|c|}{ e) Corresponde ao número de casos julgados por 100 mil habitantes } \\
\hline & ais tenha apresentado & uma inici & 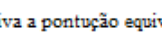 & & & & & & & & & & & & & & \\
\hline
\end{tabular}

\section{APÊNDICE 3}

Tabela 12 - Divisão dos países de acordo com o Indicador de Compliance com Normas em Tráfico de Pessoas 


\section{APÊNDICE 3}

\begin{tabular}{|c|c|c|c|c|}
\hline \multirow{2}{*}{ País } & \multirow{2}{*}{ Indicador de Compliance com Normas em Tráfico de Pessoas } & \multicolumn{3}{|c|}{ Quartil } \\
\hline & & $1^{\mathrm{o}}$ & $2^{\circ}$ & $3^{\circ}$ \\
\hline & & 3,9 & 4,9 & 5,7 \\
\hline Argentina & 5,9 & & & $\underline{\mathbf{X}}$ \\
\hline Chile & 4,1 & & $\underline{\mathbf{X}}$ & \\
\hline Costa Rica & 5,7 & & $\underline{\overline{\mathbf{X}}}$ & \\
\hline Uruguai & 3,0 & $\underline{\mathbf{X}}$ & & \\
\hline & & 3,2 & 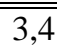 & 4,2 \\
\hline Belize & 5,3 & & & $\underline{\mathbf{X}}$ \\
\hline Brasil & 3,5 & & $\underline{\mathbf{X}}$ & \\
\hline El Salvador & 4,5 & & & $\underline{\mathbf{X}}$ \\
\hline Honduras & 3,2 & $\underline{\mathbf{X}}$ & & \\
\hline Nicarágua & 3,1 & $\underline{X}$ & & \\
\hline Venezuela & 3,2 & $\underline{\bar{X}}$ & & \\
\hline & & 4,5 & 4,7 & 5,0 \\
\hline Colômbia & 5,3 & & & $\underline{\mathbf{X}}$ \\
\hline México & 4,7 & & $\underline{\mathbf{X}}$ & \\
\hline Peru & 4,4 & $\underline{\mathbf{X}}$ & & \\
\hline
\end{tabular}


